\title{
Changes in Stratigraphic
}

Nomenclature by the U.S. Geological Survey, 1977

GEOLOGICAL SURVEY BULLETIN 1457-A 

Changes in Stratigraphic Nomenclature by the U.S. Geological Survey, 1977

By NORMAN F. SOHL and WILNA B. WRIGHT CONTRIBUTIONS TO STRATIGRAPHY

G E O L O G I C A L S U R V E Y B U L L E T I N 1457-A 


\section{UNITED STATES DEPARTMENT OF THE INTERIOR}

GECIL D. ANDRUS, Secretary

\section{GEOLOGICAL SURVEY}

H. William Menard, Director

Library of Congress catalog-card No. 79-50550

For sale by Superintendent of Documents, U.S. Government Printing Office Washington, D.C. 20402

Stock Number 024-001-03156-6 
Introduction ..................... A1

Listing of nomenclatural changes ............ 3

Revision of the age of the Pancho Rico Formation, central

Coast Ranges, California, by Warren 0. Addicott . . . . . 88

The Bugle and Witch Members of the Keating Formation, Escabrosa Group, and the Mississippian nomenclature in the Big Hatchet Mountains, Hidalgo County, New Mexico, by Augustus K. Armstrong and Bernard L. Mamet . . . . .

Revised ages of Cambrian and Ordovician formations of the Conestoga Valley near York and Lancaster, southeastern Pennsylvania, by Gregory S. Gohn

The Sandy Springs Group and related rocks in the Georgia Pledmont; nomenclature and stratigraphy, by Michael $\mathrm{W}$. Higgins and Keith I. McConnell ............

Restriction and renaming of the Neruokpuk Formation, northeastern Alaska, by Hillard N. Reiser, Donald K. Norris, J. Thomas Dutro, Jr., and William P. Brosgé . . . . . 106

Age of the Metaline Limestone or Formation in northeastern Washington, by John E. Repetski . . . . . . . . . 107

Ages of the Lee, Breathitt, Caseyville, Tradewater, and Sturgis Formations in Kentucky, by Charles L. Rice . . . . . . . 108

Coral zones and problems of Mississippian stratigraphy in the Williston basin, Montana and North Dakota, by William J. Sando

Twin River Group (upper Eocene to lower Miocene)--defined to Include the Hoko River, Makah, and Pysht Formations, Clallam County, Washington, by Parke D. Snavely, Jr.,

Alan R. Niem, and James E. Pearl ............. 111

Age and continuity of the Valdez Group, southern Alaska, by

Russell G. Tysdal and George Plafker . . . . . . . . . 120

References clted ...................... 124

Author index ....................... 133 
FIGURE 1. Index map showing localities in southeastern Arizona and southwestern New Mexico

2. Biostratigraphic and lithologic correlation diagram of Mississippian strata of the Big Hatchet Mountains, Hidalgo County, southwestern New Mexico ..................

3. Map showing location of physiographic provinces in southeastern Pennsylvania near York and Lancaster .............. . . 95

4. Enlarged Landsat image (band 7) showing the quartzite ridges of the Sandy Springs Group . . . 99

5. Diagrammatic stratigraphic column of the Sandy Springs Group .................. 100

6. County outline map of part of Georgia showing known outcrop area of the Sandy Springs Group . . 101

7. Chart showing general age relations of some Lower and Middle Pennsylvanian units in Kentucky . 109

8. Index map of the northwestern part of the Olympic Peninsula, Washington, showing distribution of the Twin River Group (upper Eocene to lower Miocene) and locations of type localities and reference sections of new formations named and described in this report . . 112

9. Chart showing comparison between the Twin River Formation of former usage with the Twin River

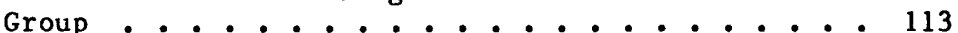

10. Generalized stratigraphic sections and benthonic foraminiferal stages for the Hoko River and Makah Formations in their type localities, Clallam County, Washington .............. 114

11. Map showing area of Valdez Group . . . . . . . 121 
TABLES

Page

TABLE 1. Stratigraphic sections of the carbonate rocks of the Lancaster-York belt of the Conestoga Valley, southeastern Pennsylvania

....... •

2. Correlation chart of Sandy Springs Group with other informal units 


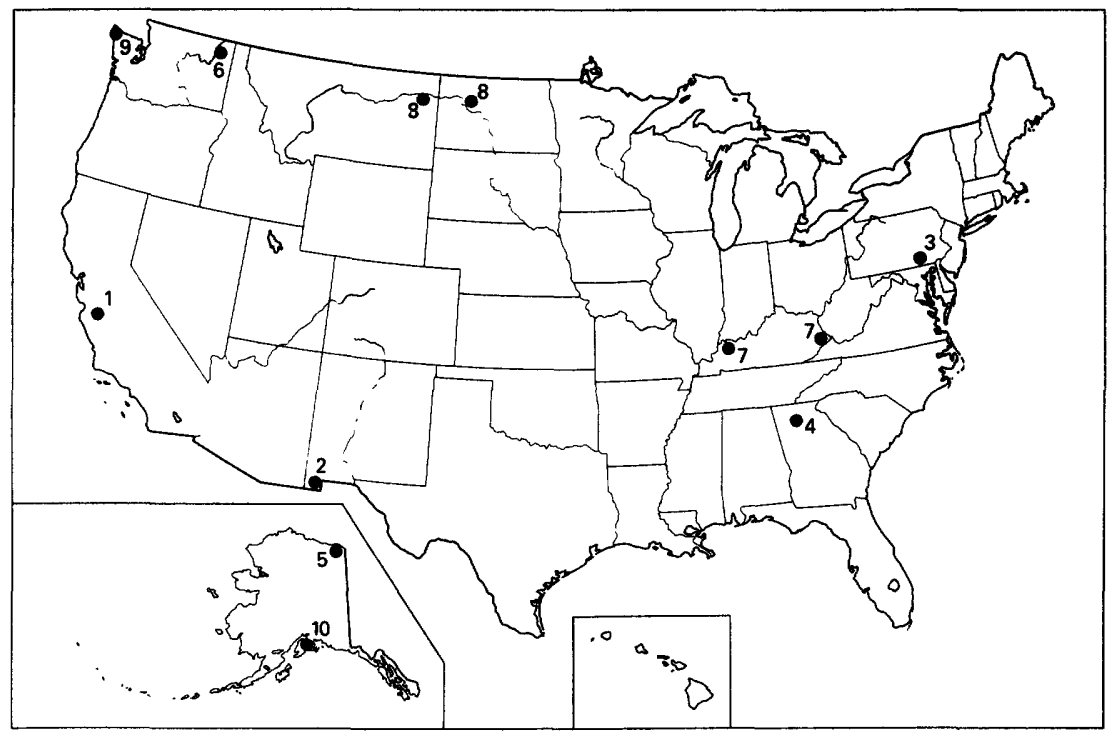

\section{GEOGRAPHIC INDEX TO ARTICLES}

1. Pancho Rico Formation, California, p. A88

2. Bugle and Witch Members of Keating Formation, New Mexico, p. A90

3. Ledger Dolomite and Conestoga Limestone, Pennsylvania, p. A94

4. Sandy Springs Group, Georgia, p. A98

5. Neruokpuk Formation, Alaska, p. A106

6. Metaline Limestone or Formation, Washington, p. A107

7. Lee, Breathitt, Caseyville, Tradewater, and Sturgis Formations, Kentucky, p. A108

8. Charles, Mission Canyon, and Kibbey Formations, Montana and North Dakota, p. A110

9. Twin River Group, Washington, p. A111

10. Valdez Group, Alaska, p. A120 


\title{
CHANGES IN STRATIGRAPHIC NOMENCLATURE
} BY THE U.S. GEOLOGICAL SURVEY, 1977

\author{
By Norman F. Sohl and Wilna B. Wright
}

\section{INTRODUCTION}

In 1971 an interim scheme for subdivision of Precambrian time was approved by the Chief Geologist for use in reports of the Geological Survey (Cohee and Wright, 1972, p. A1-A3). In the absence of an international consensus on terminology, the four subdivisions were designated as follows:

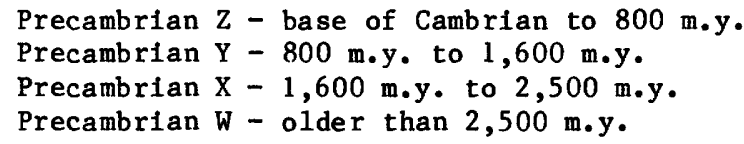

Since 1971 the Subcommission on Precambrian Stratigraphy of the International Geological Sciences has come closer to a consensus on at least the gross subdivioion of the Precambrian. James (1978) has presented the recommendations of the 1977 meeting in Cape Town, South Africa, where the subcommission voted to accept, as a first step, a twofold division of the Precambrian into Archean (Archaean) and Proterozolc Eons with the boundary defined as $2,500 \mathrm{~m} . \mathrm{y}$. This corresponds to the boundary of Precambrian $W$ and $X$ of the Survey's present scale. The Chief Geologist has approved usage of the terms Archean and Proterozoic. Pending international agreement on subdivision of the Archean, rocks of Archean age will be classified simply Archean and the old designation of Precambrian $W$ is abandoned. Pending international agreement on subdivision of the Proterozoic, the subdivisions $\mathrm{X}, \mathrm{Y}$, and $\mathrm{Z}$ of the Survey's present Precambrian scale are continued as its subdivisions (see Major Stratigraphic and Time Divisions chart below).

The previously used rock stratigraphic and time designations for the Precambrian given in the accompanying listing of nomenclatural changes were used by the authors in reports submitted to the Geologic Names Committee before the new scheme was adopted. 
MAJOR STRATIGRAPGTC AND TIME DIVISIONS

[Compiled by Geologic Names Committee, U.s. Geological Survey)

Terms desıgnating time are in parentheses. Infornal time terms ("early, "middle," and "late") may be used where there is no formal subdivision into Early, Middle, and Late for an eon, exa, period, subperiod, or epoch. Informal rock terms ("lower." "middle," and "upper") may be used where there 25 no formal subdivision into Lower, Middle, and Upper for an eon, erathem, system, subsystem, or series.

Estımates for ages of stratıgraphic and time boundaries are under continuous study and are subject to refinement and controversy. Two scales are given for comperison. If neither Geological Society of London nor Berggren reference is used, author should cite the published source that is followed. A useful time scale for North American manmalian ages is given by Evernden and others $(1964$, p. 145-198).

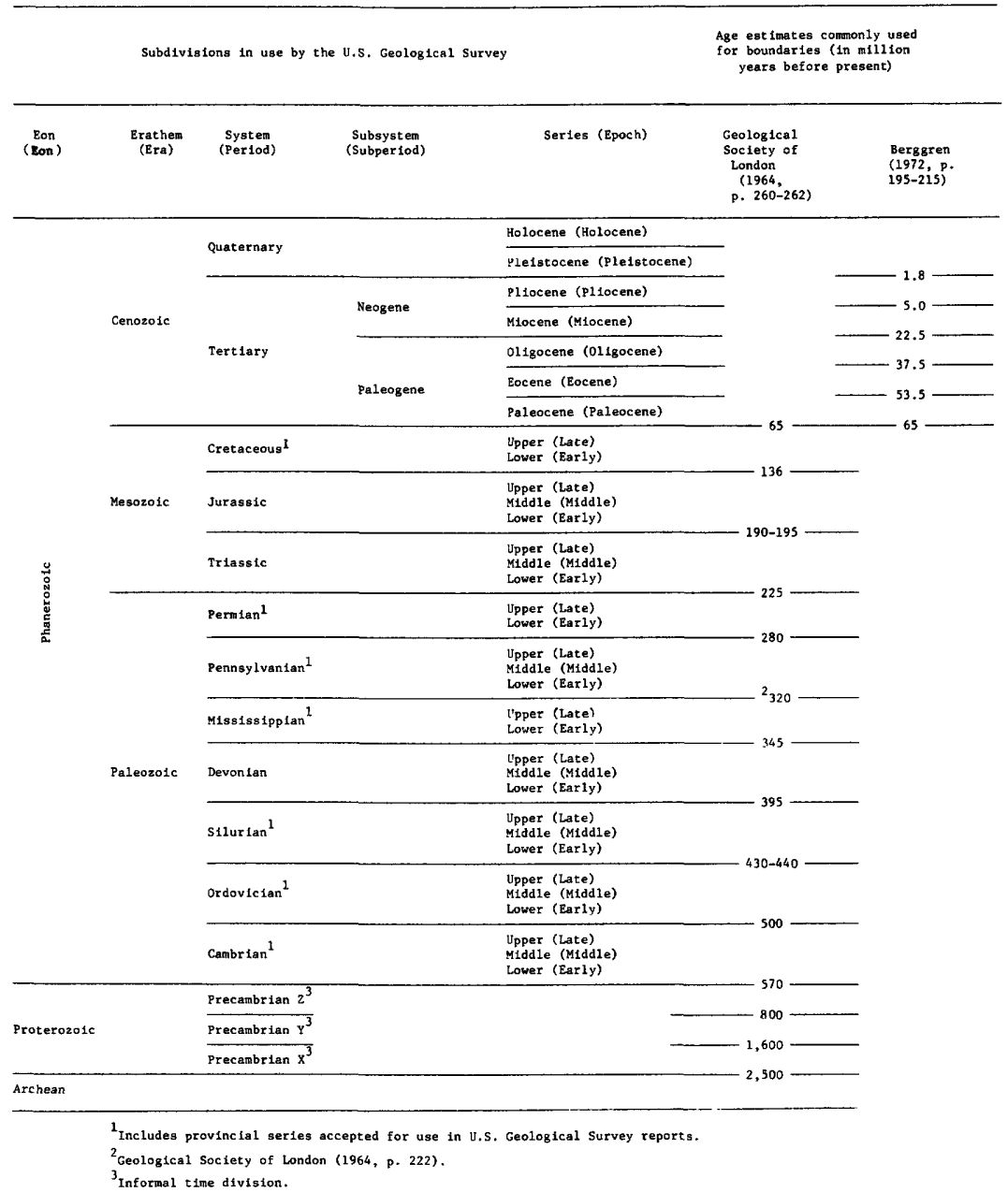

In the following listing, stratigraphic names adopted, revised, reinstated, or abandoned are Iisted alphabetically. The timestratigraphic classification (system or series) of the rockstratigraphic unit, the area involved, and the action taken, along with reference citation of the author(s), are given. The capitalization of terms follows of ficial rock-stratigraphic and time usage. 


\title{
LISTING OF NOMENCLATURAL CHANGES
}

\author{
Abrams Mica Schist (age changed) \\ Devonian \\ California
}

Irwin, W. P., 1977, Review of Paleozoic rocks of the Klamath Mountains, in Stewart, J. H., Stevens, C. H., and Fritsche, A. E., eds., Paleozoic paleogeography of the western United States, Pacific Coast Paleogeography Symposium 1: Soc. Econ. Paleontologists and Mineralogists, Pacific Sec., p. 441-454.

Age changed from Devonian or older Paleozoic to: Devonian.

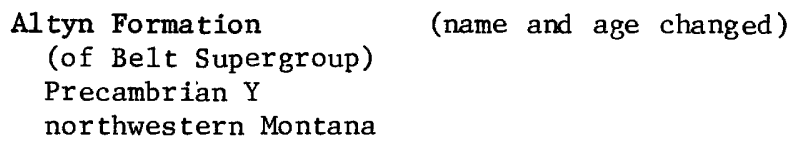

Mudge, M. R., 1977, General geology of Glacier Nationa1 Park and adjacent areas, Montana: Canadian Soc. Petroleum Geology Bull., v. 25, no. 4, p. 736-751.

Name changed from Altyn Limestone to: Altyn Formation Age changed from Precambrian to: Precambrian Y.

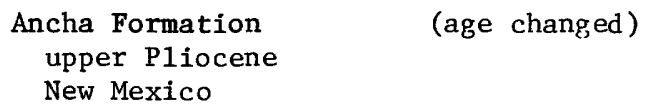

Manley, Kim, 1976, K-Ar age determinations on Pliocene basalts from the Española basin, New Mexico: Isochron/West, no. 16, p. 29, 30.

Age changed from late Pliocene or Pleistocene to: late Pliocene (K/Ar $1.96 \pm 0.06 \mathrm{~m} . \mathrm{y}$.$) .$

Andrew Lake Formation (age changed)

upper Eocene

southwestern Alaska

Hein, J. R., and McLean, Hugh, 1977, Paleogene sedimentary and volcanogenic rocks from Adak Island, central Aleutian Islands, Alaska: Geol. Soc. America Abs. with Programs, v. 9, no. 4, p. 433.

Age changed from middle or late Eocene to: late Eocene. 


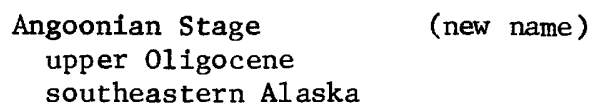

Wolfe, J. A., 1977, Paleogene floras from the Gulf of Alaska region: U.S. Geo1. Survey Prof. Paper 997, 108 p.

Angoonian Stage adopted. Overlies unnamed stage; underlies Seldovian Stage.

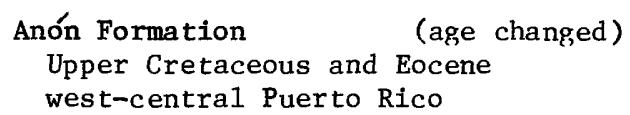

Krushensky, R. D., and Curet, A. F., 1977, Unconformity between the Late Cretaceous and early Tertiary in western Puerto Rico--a concept rejected, in Geological Survey research 1977: U.S. Geol. Survey Prof. Paper 1050, p. 91 .

Age changed from middle to late Eocene to: Late Cretaceous and Eocene.

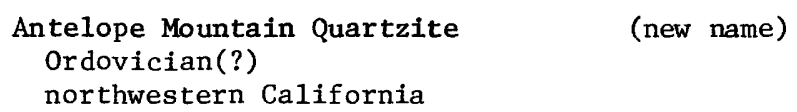

Hotz, P. E., 1977, Geology of the Yreka quadrangle, Siskiyou County, California: U.S. Geol. Survey Bull. 1436, 72 p.

Antelope Mountain Quartzite adopted. Structurally overlies Duzel Phyllite and, elsewhere, Schulmeyer Gulch sequence; underlies Hornbrook Formation and younger rocks.

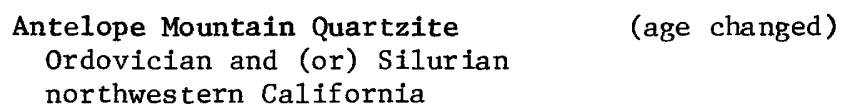

Potter, A. W., Hotz, P. E., and Rohr, D. M., 1977, Stratigraphy and inferred tectonic framework of lower Paleozoic rocks in the eastern Klamath Mountains, northern California, in Stewart, J. H., Stevens, C. H., and Fritsche, A. E., eds., Paleozoic paleography of the western United States, Pacific Coast Paleogeography Symposium 1: Soc. Econ. Paleontologists and Mineralogists, Pacific Sec. p. 421-440.

Age changed from Ordovician(?) to: Ordovician and (or) Silurian. 
Appekunny Formation

(name abandoned)

(of Ravalli Group)

(of Be1t Supergroup)

Precambrian

northwestern Montana

Mudge, M. R., 1977, General geology of Glacier National Park and adjacent areas, Montana: Canadian Soc. Petroleum Geology Bul1., v. 25, no. 4, p. 736-751.

Appekunny Formation abandoned; its rocks replaced by Greyson Formation (or Shale).

\author{
Ardmore Bentonite Bed \\ (of Cokedale Formation) \\ (of Two Medicine Formation) \\ Upper Cretaceous \\ southwestern and northwestern Montana
}

Rice, D. D., 1976, Stratigraphic sections from well logs and outcrops of Cretaceous and Paleocene rocks, northern Great Plains, Montana: U.S. Geol. Survey $0 i 1$ and Gas Inv. Chart $0 \mathrm{C}-71,3$ sheets.

In Livingston area and Crazy Mountains Basin of southwestern Montana, reassigned to Cokedale Formation; west of Sweetgrass Arch of northwestern Montana, reassigned to Two Medicine Formation. Ardmore Bentonite Bed remains good usage elsewhere in Montana and in South Dakota, North Dakota, Wyoming, and Colorado, assigned to other formations.

\section{Ardmore Bentonite Bed (of Pembina Member)

Rice, D. D., 1977, Stratigraphic sections from well logs and outcrops of Cretaceous and Paleocene rocks, northern Great Plains, North Dakota and South Dakota: U.S. Geol. Survey $0 i 1$ and Gas Inv. Chart OC-72, 3 sheets.

Geographically extended into North Dakota and reassigned from Sharon Springs Member of Pierre Shale in South Dakota and Wyoming to: Pembina Member of Pierre Shale in that North Dakota location only. Ardmore Bentonite Bed remains good usage elsewhere in Sharon Springs Member of Pierre or in other formations in Montana, Wyoming, and Colorado. 


\section{Arkose Ridge Formation (age changed)}

\section{Cretaceous}

Alaska

Csejtey, Béla, Jr., Nelson, W. H., Eberlein, G. D., Lanphere, M. A., and Smith, J. G., 1977, New data concerning the age of Arkose Ridge Formation, south-central Alaska, in K. M. Bleam, ed., The United States Geological Survey in Alaska: Accomplishments during 1976: U.S. Geo1. Survey Circ. 751-B, p. B62-B64 .

Age changed from Paleocene to: Cretaceous.

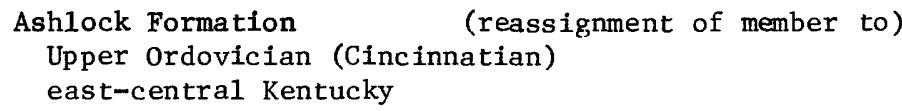

Weir, G. W., and McDowe11, R. C., 1976, Geologic map of the Preston quadrangle, Bath and Montgomery Counties, Kentucky: U.S. Geo1. Survey Geol. Quad Map GQ-1334.

In report area only, Sunset Member of Bull Fork Formation reassigned to top of underlying Ashlock Formation. Ashlock usage remains unchanged elsewhere in Kentucky.

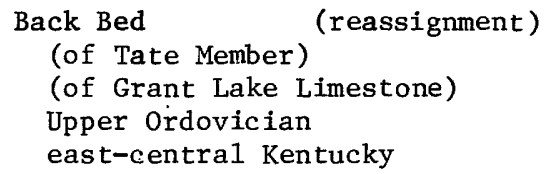

Blade, L. V., 1977, Geologic map of the Sharpsburg quadrangle, eastcentra1 Kentucky: U.S. Geol. Survey Geol. Quad. Map GQ-1419.

Back Bed of Tate Member of Ashlock Formation reassigned to: Tate Member of Grant Lake Limestone in this area; still assigned to Tate Member of Ashlock elsewhere.

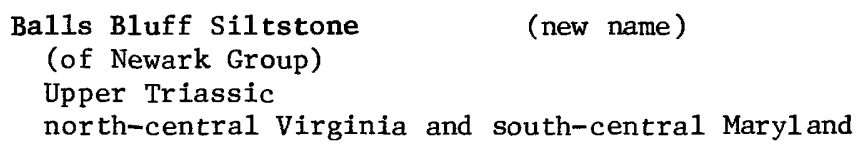

Balls Bluff Siltstone adopted and assigned to Newark Group as middle of three formations. Overlies Manassas Sandstone of Newark; underlies Bull Run Formation of Newark. 
Baltimore Complex

lower Paleozoic

(geographic extension)

south-central Maryland and northern Virginia

Morgan, B. A., 1977, The Baltimore Complex, Maryland, Pennsylvania, and Virginia, in Coleman, R. G., and Irwin, W. P., eds., North American ophiolites: Oregon Dept. Geology and Mineral Industries Bull. 95, p. 41-45

Geographically extended from central and northeastern Maryland and southeastern Pennsylvania into: south-central Maryland and northern Virginia.

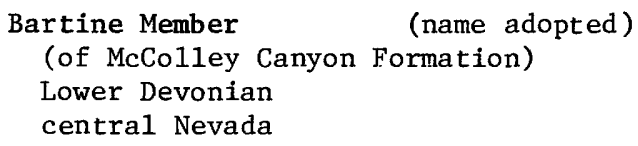

Berdan, J. M., ]977, Ear1y Devonian ostracode assemblages from Nevada, in Murphy, M. A. and others, eds., Western North America: Devonian: Riverside, Calif., Univ. California, Riverside Campus Museum Contrib. no. 4, p. 55-64.

Bartine Member of Murphy and Gronberg (1970) adopted as middle of three members of McColley Canyon Formation. Overlies Kobeh Member and underlies Coils Creek Member, both of McColley Canyon.

\author{
Baseline Sandstone (subdivided) \\ Lower and Upper Cretaceous \\ southeastern Nevada
}

Bohannon, R. G., 1976, The tectonic and sedimentologic environment of lithium occurrences in the Muddy Mountains, Clark County, Nevada, in Vine, J. D., ed., Lithium resources and requirements by the year 2000: U.S. Geol. Survey Prof. Paper 1005, p 109-116.

In southeastern Nevada, Baseline divided into: unnamed sandstone member intertongued with Overton Conglomerate Member (now reduced in rank); former usage of Baseline in Arizona remains unchanged.

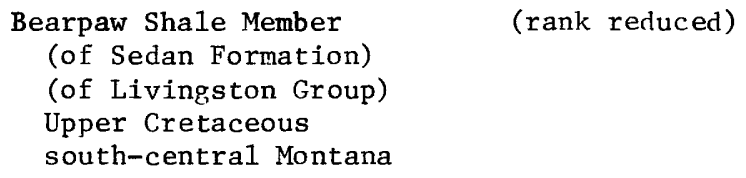

Skipp, Betty, and McGrew, L. W., 1977, The Maudlow and Sedan Formations of the Upper Cretaceous Livingston Group on the west edge of the Crazy Mountains basin, Montana: U.S. Geol. Survey Bull. 1422-B, 68 p. 
In Sedan-Ringling area of south-central Montana, reduced in rank from Bearpaw Shale to: Bearpaw Shale Member and reassigned to Sedan Formation (new name) of Livingston Group. Dverlies unnamed mudstone member of Sedan; underlies Lennep Sandstone Member (also reduced in rank) of Sedan. Usage of Bearpaw Shale of Montana Group remains unchanged in Nyoming, and els ewhere in Montana.

\title{
Beaufort Formation (geographic extension?) \\ Paleocene
}

South Carolina(?)

Gohn, G. S., Higgins, B. B., Smith, C. C., and Owens, J. P., 1977, Lithostratigraphy of the deep corehole (Clubhouse Crossroads corehole 1) near Charleston, South Carolina, in Rankin, D. W., ed., Studies related to the Charleston, South Carolina, earthquake of 1886--a preliminary report: U.S. Geo1. Survey Prof. Paper 1028-E, p. 59-70.

Geographically extended (tentatively) into subsurface of eastern South Carolina; remains good usage in North Carolina.

\section{Beaverhead Formation (age variation) \\ Lower(?) Cretaceous to Eocene (varies) \\ eastern Idaho}

Skipp, Betty, and Hait, M. H., Jr., 1977, Allochthons along the northeast margin of the Snake River Plain, Idaho, in Joint Wyoming-Montana-Utah Geol. Assoc. Guidebook, 29th Ann. Field Conf., Teton Village, Nyoming: p. 499-515.

In Snake River Plain, Idaho, age changed from Late Cretaceous to Eocene to: Early(?) Cretaceous to Eocene; age varies elsewhere.

\author{
Beekmantown Dolomite (assignment to group) \\ (of Knox Group) \\ Lower Ordovician \\ southwestern Virginia
}

Miller, R. L., and Meissner, C. R., Jr., 1977, Geologic map of the Big A Mountain quadrangle, Buchanan and Russe11 Counties, Virginia: U.S. Geol. Survey Geol. Quad. Map GQ-1350.

In southwestern Virginia only, Beekmantown Dolomite assigned to Knox Group as upper of two formations; overlies Copper Ridge Dolomite of Knox and underlies unnamed Middle Ordovician limestones. Beekmantown Shale, Limestone, Dolomite, or Group remains good usage elsewhere in Virginia, and in West Virginia, Maryland, Pennsylvania, New Jersey, and New York. 
Begg Member

(name adopted)

(of Vester Formation)

Upper Triassic (Carnian)

northeastern Oregon

Brown, C. E., and Thayer, T. P., 1977, Geologic map of pre-Tertiary rocks in the eastern Aldrich Mountains and adjacent areas to the south, Grant County, Oregon: U.S. Geol. Survey Misc. Geol. Inv. Map I-1021.

Begg Formation of Dickinson and Vigrass (1965) adopted as lower of two members of Vester Formation. Unconformably overlies Paleozoic rocks; conformably underlies Brisbois Member (also newly adopted) of Vester.

\author{
Belchertown Quartz Monzodiorite (name changed) \\ Devonian \\ Massachusetts
}

Leo, G. W., Robinson, Peter, and Hall, D. J., 1977, Bedrock geologic map of the Ludlow quadrangle, Hampden and Hampshire Counties, south-central Massachusetts: U.S. Geol. Survey Geo1. Quad. Map GQ-1353.

Name changed from Belchertown Tonalite to: Belchertown Quartz Monzodiorite.

\author{
Be1t Supergroup (its formations revised) \\ Precambrian $\mathrm{Y}$ \\ northwestern Montana
}

Mudge, M. R., 1977, General geology of Glacier National Park and adjacent areas, Montana: Canadian Soc. Petroleum Geology Bul1., v. 25, no. 4, p. 736-751.

Its Appekunny Formation abandoned and replaced by Greyson Formation. Name of its Altyn Limestone changed to Altyn Formation. Age of its Altyn Formation changed from Precambrian to: Precambrian Y. Belt remains in good usage in Idaho and Washington and elsewhere in Montana.

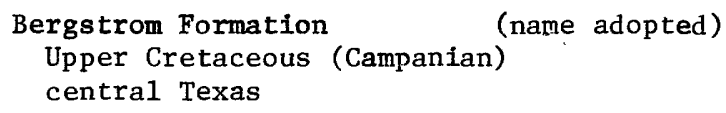

Hazel, J. E., Bybe11, L. M., Christopher, R. A., Frederiksen, N. 0., May, F. E., McLean, D. M., Poore, R. Z., Smith, C. C., Soh1, N. F., Valentine, P. C., and Witmer, R. J., 1977, Biostratigraphy of the deep corehole (C1ubhouse Crossroads corehole 1) near Charleston, South Carolina, in Rankin, D. ed., Studies related to the Charleston, South Carolina, earthquake of 1886-a preliminary report: U.S. Geol. Survey Prof. Paper 1028-F, p. 71-89. 
Bergstrom Formation of Young (1965) adopted. Overlies Pecan Gap Cha1k of Taylor Group (both raised in rank); underlies Neylandville Mar1.

\title{
Bigby Limestone
}

(of Nashville Group)

Middle Ordovician

Tennessee

Harris, L. D., and Milici, R. C., 1977, Characteristics of thin-skinned style of deformation in the southern Appalachians and potential hydrocarbon traps: U.S. Geo1. Survey Prof. Paper 1018, 40 p.

Assigned to Nashville Group (now reinstated) as one of four formations. Overlies Hermitage Limestone or Formation; underlies Catheys Limestone or Formation; as western facies, correlates with $\Leftrightarrow$, Cannon Limestone (eastern facies)--all of Nashville.

\section{Big Dome Formation (age changed)}

lower Miocene

southeastern Arizona

Banks, N. G., and Krieger, M. H., 1977, Geologic map of the Hayden quadrangle, Pinal and Gila Counties, Arizona: U.S. Geol. Survey Geol. Quad. Map GQ-1391.

Age changed from middle Miocene to: early Miocene.

\author{
B1ack Rock Limestone Member (rank reduced) \\ (of Smithville Formation) \\ Lower Ordovician \\ northeastern Arkansas
}

Wise, O. A., Jr., Yochelson, E. L., and Clardy, B. F., 1975, Lower Ordovician stratigraphic relations at Smithville, Arkansas, and adjacent areas, in Contributions to geology of the Arkansas Qzarks, 1975: Arkansas Geol. Comm. Pub., p. 38-60.

B1ack Rock Formation reduced in rank to Black Rock Limestone Member and assigned to Smithville Formation.

\author{
Blanca Formation (name adopted) \\ Miocene \\ Santa Cruz Island off southern California coast
}

McLean, Hugh, Howe11, D. G., and Vedder, J. G., 1976, Miocene strata on Santa Cruz and Santa Rosa Islands--a reflection of tectonic events in the southern California borderland, in Howell, D. G., ed., Aspects of the geologic history of the California continental borderland: Am. Assoc. Petroleum Geologists Misc. Pub. 24, p. 241-253. 
Blanca Tuff of Rand (1931) adopted as Blanca Formation as redefined by Weaver and others (1969). Conformably overlies San Onofre Breccia or Rincon Formation; unconformably abuts villows Diorite; underlies Quaternary deposits.

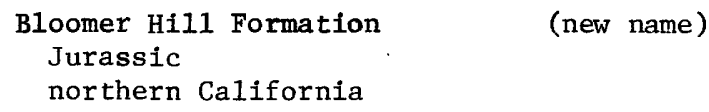

Hietanen, Anna, 1977, Paleozoic-Mesozoic boundary in the Berry Creek quadrangle, northwestern Sierra Nevada, California: U.S. Geol. Survey Prof. Paper 1027, 22 p.

Bloomer Hill Formation adopted; in fault contact with Paleozoic rocks.

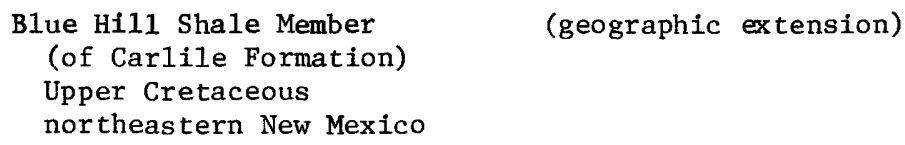

Pillmore, C. L., and Eicher, D. L., 1976. Lower part of the marine Cretaceous at Gold Creek Vermejo Park, New Mexico, in New Mexico Geo1. Soc. Guidebook, 27th Field Conf., Vermejo Park, 1976: p. 171-176.

Geographically extended from Kansas, Nebraska, and Colorado into: northeastern New Mexico as middle of three named members of Carlile Formation (name changed from Carlile Shale); overlies Fairport Member and underlies Juana Lopez Member (both also geographically extended; both of Carlile). Blue Hill Shale Member of Carlile Shale remains in good usage in Kansas, Nebraska, and Colorado.

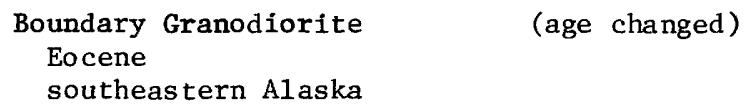

Smith, J. G., 1977, Geology of the Ketchikan D-1 and Bradford Canal A-1 quadrangles, southeastern Alaska: U.S. Geol. Survey Bull. 1425, 49 p.

Age changed from Jurassic or Cretaceous to: Eocene. 


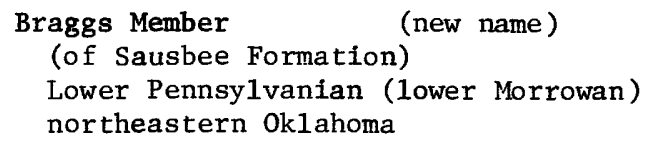

Sutherland, P. K., and Henry, T. W., 1977, Carbonate platform facies and new stratigraphic nomenclature of the Morrowan Series (Lower and Middle Pennsylvanian), northeastern Oklahoma: Geol. Soc. America Bul1., v. 88, no. 3, p. 425-440.

Braggs Member adopted as lower of two members of Sausbee Formation (new name). Unconformably overlies Pitkin Limestone; conformably underlies Brewer Bend Limestone Member (new name) of Sausbee.

\title{
Brewer Bend Limestone Member (new name) \\ (of Sausbee Formation) \\ Lower Pennsylvanian (1ower Morrowan) \\ northeastern Oklahoma
}

Sutherland, P. K., and Henry, T. W., 1977, Carbonate platform facies and new stratigraphic nomenclature of the Morrowan Series (Lower and Middle Pennsylvanian), northeastern Oklahoma: Geol. Soc. America Bull., v. 88, no. 3, p. 425-440.

Brewer Bend Limestone Member adopted as upper of two members of Sausbee Formation (new name). Conformably overlies Braggs Member (new name) of Sausbee; unconformably underlies McCully Formation (new name).

\author{
Bridge Creek Limestone Member (geographic extension) \\ (of Greenhorn Formation) \\ Upper Cretaceous \\ northeastern New Mexico
}

Pillmore, C. L., and Eicher, D. L., 1976. Lower part of the marine Cretaceous at Gold Creek Vermejo Park, New Mexico, in New Mexico Geol. Soc. Guidebook, 27th Field Conf., Vermejo Park, 1976: p. 171-176.

Geographically extended from Kansas and Colorado into: northeastern New Mexico as uppermost of three members of Greenhorn Formation. Dverlies Hartland Member of Greenhorn (also geographically extended); underlies Carlile Formation (name changed from Carlile Shale). Bridge Creek Limestone Member of Greenhorn Limestone remains in good usage in Kansas and Colorado. 
Brightseat Formation

(of Pamunkey Group)

Paleocene

north-central Virginia (geographic extension)

Bybe11, L. M., and Govon1, D. L., 1977, Preliminary calcareous nannofossil zonation of Brightseat and Aquia Formations (Paleocene) of Maryland and Virginia--stratigraphic implications [abs.], in Am. Assoc. Petroleum Geologists-Soc. Econ. Paleontologists and Mineralogists Program and Abstracts, June 12-16, 1977: p. 67.

Geographically extended into north-central Virginia from Maryland.

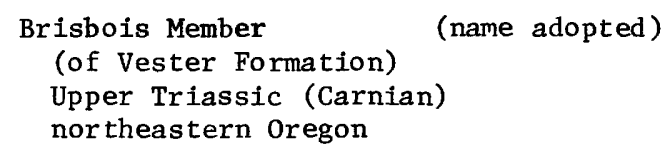

Brown, C. E., and Thayer, T. P., 1977, Geologic map of pre-Tertiary rocks in the eastern Aldrich Mountains and adjacent areas to the south, Grant County, Oregon: U.S. Geol. Survey Misc. Geol. Inv. Map I-1021.

Brisbois Formation of Dickinson and Vigrass (1965) adopted as upper of two members of Vester Formation. Conformably overlies Begg Member (also newly adopted) of Vester; unconformably underlies Rail Cabin Argillite (also newly adopted).

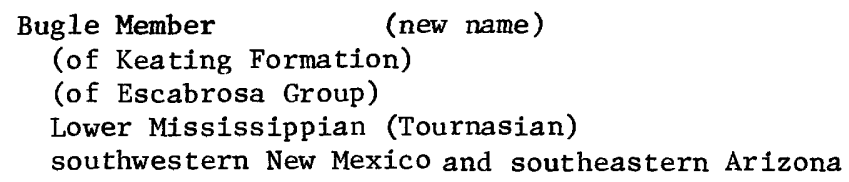

Armstrong, A. K., and Mamet, B. L., The Bugle and Witch Members of the Keating Formation, Escabrosa Group, and the Mississippian nomenclature in the Big Hatchet Mountains, Hidalgo County, New Mexico: this report.

Bugle Member adopted as lower of two members of Keating Formation. Unconformably overlies Percha Shale; conformably underlies Witch Member (new name of Keating).

\section{Bul1 Run Formation (name adopted)}

(of Newark Group)

Upper Triassic and Lower Jurassic(?)

north-central Virginia and south-central Maryland

Lee, K. Y., 1977, Triassic stratigraphy in the northern part of the Culpeper basin, Virginia and Maryland: U.S. Geol. Survey Bull. 1422-C, 17 p. 
Bull Run Shales of Roberts (1923) adopted as Bull Run Formation and assigned to Newark Group as uppermost of three formations. Divided into (ascending): Leesburg Limestone Conglomerate Member (new name) and unnamed basaltic flow-bearing clastics member. Overlies Balls Bluff Siltstone (new name) of Newark Group.

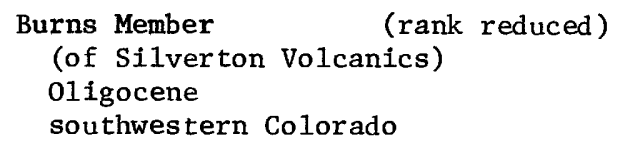

Lipman, P. W., 1976, Geologic map of the Lake City caldera area, western San Juan Mountains, southwestern Colorado: U.S. Geol. Survey Misc. Inv. Map I-962.

Reduced in rank from Burns Formation to: Burns Member; assigned to Silverton Volcanics (now reinstated and reduced in rank).

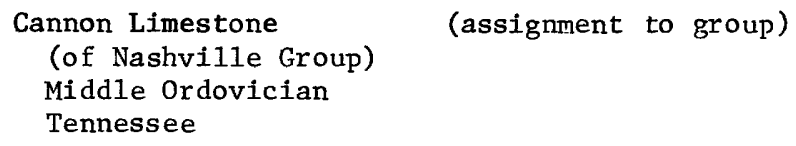

Harris, L. D., and Milici, R. C., 1977, Characteristics of thin-skinned style of deformation in the southern Appalachians and potential hydrocarbon traps: U.S. Geo1. Survey Prof. Paper 1018, 40 p.

In Tennessee only, assigned to Nashville group (now reinstate) as one of four formations. Overlies Hermitage Limestone or Formation; underlies Catheys Limestone or Formation; as eastern facies, correlates with $(\Leftrightarrow)$, Bigby Limestone (western facies)--all of Nashville. Cannon Limestone remains in good usage in Virginia.

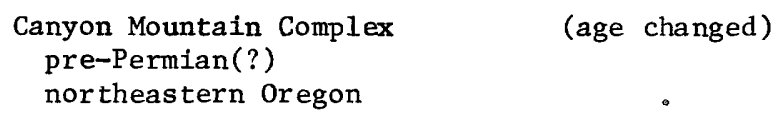

Age changed from Early and Middle Triassic to: pre-Permian(?).

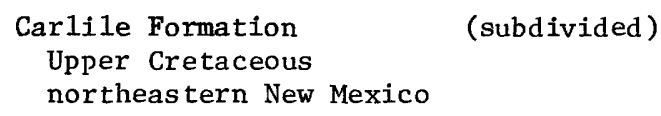

Pillmore, C. L., and Eicher, D. L., 1976. Lower part of the marine Cretaceous at Gold Creek Vermejo Park, New Mexico, in New Mexico Geol. Scc. Guidebook, 27th Field Conf., Vermejo Park, 1976: p. 171-176. 
In northeastern New Mexico, Carlile Formation (name changed from Carlile Shale) divided into by geographic extension (ascending): Fairport, Blue Hill Shale, and Juana Lopez Members and uppermost unnamed black shale unit. Carlile Shale of Colorado or Benton Group and Carlile Shale Member of Mancos or Cody or Colorado Shale remain in good usage in Colorado, Nebraska, North and South Dakota, Wyoming, Kansas, Montana, and elsewhere in New Mexico.

\section{Caseyville Formation (age changed) Lower and Middle Pennsylvanian (Morrowan) Kentucky}

Rice, C. L., Ages of the Lee, Breathitt, Caseyville, Tradewater, and Sturgis Formations in Kentucky: this report.

Age changed from Early Pennsylvanian to: Early and Middle Pennsylvanian (early and late Morrowan). Caseyville remains in good usage in Illinois as formation of McCormick Group. Ages of its Members (ascending): Lusk, Battery Rock Sandstone, and Pounds Sandstone, not changed in this report.

\section{Catahoula Sandstone (age changed) \\ oligocene and Miocene (varies) \\ Texas}

Hazel, J. E., Bybe11, L. M., Christopher, R. A., Frederiksen, N. O., May, F. E., McLean, D. M., Poore, R. Z., Smith, C. C., Sohl, N. F., Valentine, P. C., and Witmer, R. J., 1977, Biostratigraphy of the deep corehole (Clubhouse Crossroads corehole 1) near Charleston, South Carolina, in Rankin, D. W. ed., Studies related to the Charleston, South Carolina, earthquake of 1886-a preliminary report: U.S. Geo1. Survey Prof. Paper 1028-F, p. 71-89.

Catahoula Sandstone used in northeastern Texas; Catahoula Tuff still remains good usage in southern Texas. Catahoula Sandstone remains good usage in Louisiana, Mississippi, and Alabama. Age changed from 0ligocene(?), Miocene(?), and Miocene to: Oligocene and Miocene (varies locally).

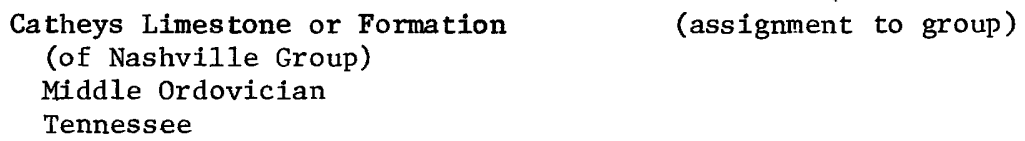

Harris, L. D., and Milici, R. C., 1977, Characteristics of thin-skinned style of deformation in the southern Appalachians and potential hydrocarbon traps: U.S. Geol. Survey Prof. Paper 1018, 40 p. 
In Tennessee only, assigned to Nashville Group (now reinstated) as uppermost of four formations. Overlies Bigby Limestone (west facies) or $(\Leftrightarrow)$ Cannon Limestone (east facies) of Nashville; underlies Leipers Limestone. Catheys Limestone or Formation remains in good usage in Alabama.

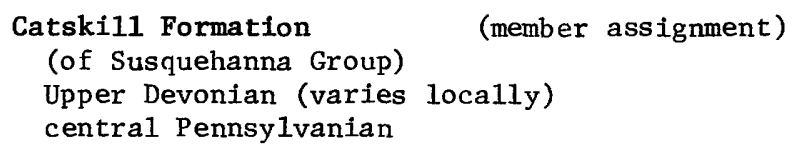

Taylor, A. R., 1977, Geology and mineral resources of the Lock Haven 7-1/2-minute quadrangle, Clinton and Lycoming Counties, Pennsylvania: Pennsylvania Topog. and Geol. Survey Atlas 124a.

Divided into (ascending): Irish Valley, Sherman Creek (newly adopted), and Duncannon Members. Age of Catskill is Late Devonian only in report area; age remains Middle Devonian to Early Mississippian elsewhere (varying locally). Usage of Catskill Formation or Red Beds remains unchanged elsewhere in Pennsylvania, New York, Maryland, and Ohio.

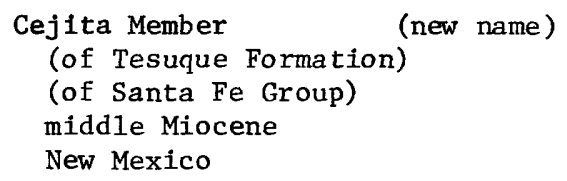

Manley, Kim, 1977, Geologic map of the northeastern part of the Española basin, New Mexico, showing the Cejita Member (new name) of the Tesuque Formation: U.S. Geol. Survey Misc. Field Studies Map MF-877.

Cejita Member adopted as upper part of Tesuque Formation of Santa Fe Group. Overlies unnamed eolian sand of Tesuque; underlies unnamed Pliocene(?) gravel.

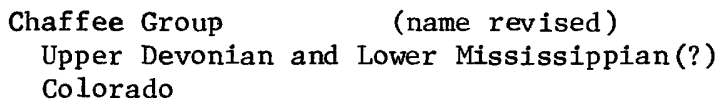

Tweto, Ogden, and Lovering, T. S., 1977, Geology of the Minturn 15-minute quadrangle, Eagle and Summit Counties, Colorado: U.S. Geol. Survey Prof. Paper 956, 96 p. 
Raised in rank from Chaffee Formation to: Chaffee Group and divided into (ascending): Parting Formation (now raised in rank from Parting Quartzite Member or Parting Member of Chaffee), Dyer Dolomite (now raised in rank from Dyer Dolomite Member or Dyer Member of Chaffee), and Gilman Sandstone (now raised in rank from Gilman Sandstone Member of Leadville Limestone or Dolomite). Age changed from Late Devonian to: Late Devonian and Early Mississippian(?).

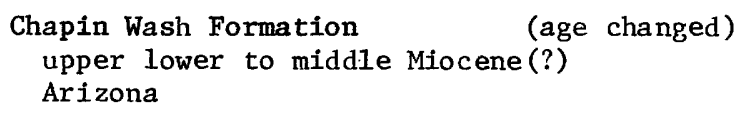

Otton, J. K., 1977, Geology of uraniferous Tertiary rocks in the Artillery Peak-Date Creek basin, west-central Arizona, in Short papers of the U.S. Geological Survey Uranium-Thorium Symposium: T. S. Geol. Survey Circ. 753, p. 35-36.

Age changed from early Pliocene(?) to: late early to middle Miocene(?).

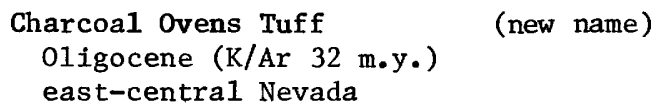

Hose, R. K., and Blake, M. C., Jr., 1976, Geology and mineral resources of White Pine County, Nevada--Pt. I, Geology: Nevada Bur. Mines and Geology Bull. 85, p. 1-35.

Charcoal Ovens Tuff adopted; apparently geographically restricted to White Pine County. Locally overlies Sheep Pass Formation or, elsewhere, Permian strata; underlies Windous Butte Formation.

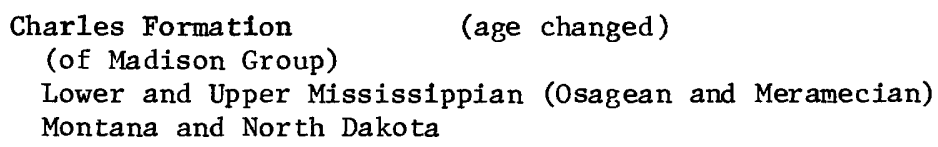

Sando, W. J., Coral zones and problems of Mississippian stratigraphy in the Williston Basin, Montana and North Dakota: this report.

Age changed from Late Mississippian to: Early and Late Mississippian to: Early and Late Mississippian (Osagean and Meramecian). Charles remains good usage elsewhere in Montana and in South Dakota. 


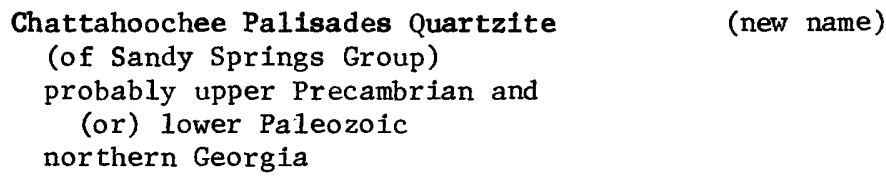

Higgins, M. H., and McConnell, K. I., The Sandy Springs Group and related rocks in the Georgia Piedmont: nomenclature and stratigraphy: this report.

Chattahoochee Palisades Quartzite adopted and assigned as one of four formations to Sandy Springs Group. Overlies Powers Ferry Formation and underlies Factory Shoals Formation (both of Sandy Springs Group; both new names).

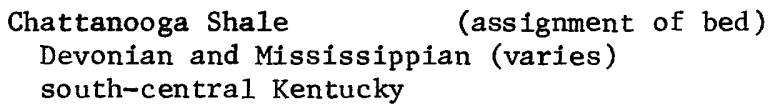

Provo, L. J., Kepferle, R. C., and Potter, P. E., 1977, Three Lick Bed: useful stratigraphic marker in Upper Devonian shale in eastern Kentucky and adjacent areas of Ohio, West Virginia, and Tennessee: U.S. Dept. Commerce, Natl. Tech. Inf. Service, ERDA-MERC/CR-77-2, 56 p.

Three Lick Bed adopted and assigned to: 1) Ohio Shale in northeastern Kentucky, Ohio, and West Virginia; 2) New Albany Shale in east-central Kentucky (correlates with lower part of Camp Run Member, of local usage, of New Albany in Indiana); and 3) Chattanooga Shale in south-central Kentucky (correlates with middle unit of Gassaway Member of Chattanooga in Tennessee). Chattanooga usage remains unchanged in Tennessee, Arkansas, Oklahoma, Alabama, Kansas, Missouri, 'Illinois, and Virginia.

Chemung Formation

(geographic restriction)

Upper Devonian

central Pennsylvania

Taylor, A. R., 1977, Geology and mineral resources of the Lock Haven 7-1/2-minute quadrangle, Clinton and Lycoming Counties, Pennsylvania: Pennsylvania Topog. and Geol. Survey Atlas 124a.

Chemung Formation abandoned in Pennsylvania; its rocks now included in Lock Haven Formation (newly adopted) of Susquehanna Group. Chemung usage remains unchanged in New York, Maryland, Virginia, and West Virginia.

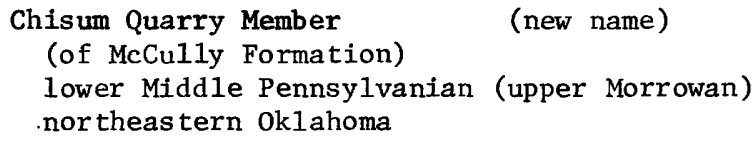


Sutherland, P. K., and Henry, T. W., 1977, Carbonate platform facies and new stratigraphic nomenclature of the Morrowan Series (Lower and Middle Pennsylvanian), northeastern Oklahoma: Geol. Soc. America Bull., v. 88, no. 3, p. 425-440.

Chisum Quarry Member adopted as lower of two named members of McCully Formation (new name). Unconformably overlies Sausbee Formation (new name); conformably underlies shale "A" member (informal name) of McCully.

\section{Chitka Point Formation}

middle Miocene (14-12 m.y.)

southwestern Alaska

\section{(age changed)}

Scholl, D. W., Marlow, M. S., McLeod, N. S., and Buffington, E. C., 1976, Episodic Aleutian Ridge igneous activity: implications of Miocene and younger submarine volcanism west of Buldir Island: Geol. Soc. America Bul1., v. 87, no. 4, p. 547-554.

Age changed from Miocene to: middle Miocene (14-12 m.y.).

\section{Chuska Sandstone (age changed)}

Eocene(?) to lower Oligocene

Arizona and New Mexico

Hackman, R. J., and 01son, A. B., 1977, Geology, structure, and uranium deposits of the Gallup $1^{\circ} \times 2^{\circ}$ quadrangle, New Mexico and Arizona: U.S. Geol. Survey Misc. Geol. Inv. Map I-981, 2 sheets.

Age changed from Pliocene(?) to: Eocene(?) to early 0ligocene.

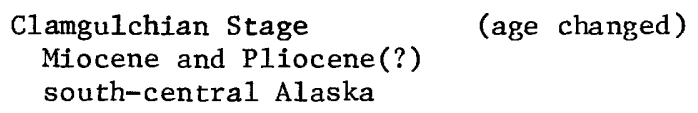

Triplehorn, D. M., Turner, D. L., and Naeser, C. W., 1977, K-Ar and fission-track dating of ash partings in coal beds from the Kenai Peninsula, Alaska: a revised age for the Homerian Stage-Clamgulchian Stage boundary: Geol. Soc. America Bull., v. 88, no. 8, p. 1156-1160. Age changed from Miocene(?) and Pliocene to: Miocene and Pliocene(?).

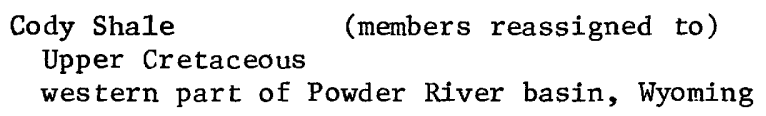


Merewether, E. A., Cobban, W. A., Matson, R. M., and Magathan, W. J., 1977, Stratigraphic diagrams with electric logs of Upper Cretaceous rocks, Powder River basin, Natrona, Campbel1, and Weston Counties, Wyoming. Section B-F' U.S. Geol. Survey 0il and Gas Inv. Chart 0C-74.

Sage Breaks and overlying Niobrara Members reassigned to base of Cody Shale in western part of Powder River basin, Wyoming. Sage Breaks Member of Carlile Shale still in good usage in eastern part of Powder River basin, Montana and Wyoming.

\author{
Coils Creek Member (name adopted) \\ (of McColley Canyon Formation) \\ Lower Devonian \\ central Nevada
}

Berdan, J. M., ]977, Early Devonian ostracode assemblages from Nevada, in Murphy, M. A. and others, eds., Western North America: Devonian: Riverside, Calif., Univ. California, Riverside Campus Museum Contrib. no. 4 , p. 55-64.

Coils Creek Member of Murphy and Gronberg (1970) adopted as uppermost of three members of McColley Canyon Formation. Overlies Bartine Member of McColley Canyon; underlies Denay Limestone of Johnson (1965).

\title{
Cokedale Formation \\ (bed reassignment)
}

Upper Cretaceous

southwestern Montana

Rice, D. D., 1976, Stratigraphic sections from well logs and outcrops of Cretaceous and Paleocene rocks, northern Great Plains, Montana: U.S. Geol. Survey $0 i 1$ and Gas Inv. Chart OC-71, 3 sheets.

Ardmore Bentonite Bed reassigned to Cokedale Formation in Livingston area and Crazy Mountains Basin of southwestern Montana; Ardmore reassigned to Two Medicine Formation west of Sweetgrass Arch in northwestern Montana. Ardmore not assigned to Cokedale elsewhere in Montana.

\section{Conestoga Limestone (age changed) \\ Middle(?) Cambrian to Lower Ordovician(?) \\ southeastern Pennsylvania}

Gohn, G. S., Revised ages of Cambrian and Ordovician formations of the Conestoga Valley near York and Lancaster, southeastern Pennsylvania: this report.

Age changed from Early Ordovician to: Middle(?) Cambrian to Early Ordovician(?). Remains good usage elsewhere in Pennsylvania. 


\author{
Continental Granodiorite \\ (of Santa Catalina Group) \\ (assignment to group) \\ Precambrian Y \\ southeastern Arizona
}

Drewes, Harald, 1977, Geologic map and sections of the Rincon Valley quadrangle, Pima County, Arizona: U.S. Geol. Survey Misc. Inv. Map I-997.

Assigned as middle of three formations of Santa Catalina Group. Overlies Pinal Schist of Santa Catalina; underlies Wrong Mountain Quartz Monzonite (new name) of Santa Catalina.

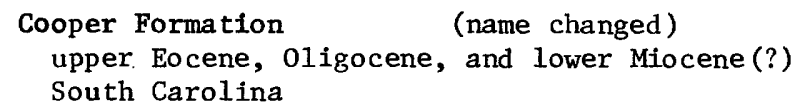

Gohn, G. S., Higgins, B. B., Smith, C. C., and Owens, J. P., 1977, Lithostratigraphy of the deep corehole (clubhouse Crossroads corehole 1) near Charleston, South Carolina, in Rankin, D. W., ed., Studies related to the Charleston, South Carolina, earthquake of 1886--a preliminary report: U.S. Geol. Survey Prof. Paper 1028-E, p. 59-70.

Name changed from Cooper Mar1 to: Cooper Formation (Eocene and 0ligocene only) in report area. Cooper Marl still remains in good usage (usually locally) elsewhere in South Carolina and in Georgia.

Coos Conglomerate Member (of Empire Formation)

(rank reduced and age changed)

lower upper Miocene southwestern Oregon

Addicott, W. 0., 1976, Neogene molluscan stages of Oregon and Washington, in Fritsche, A. E., and others, eds., The Neogene Symposium, Pacific Coast of North America, Soc. Econ. Paleontologists and Mineralogists, Pacific Sec., San Francisco, California, April 1976: p. 95-115.

Coos Conglomerate reduced in rank to Coos Conglomerate Member and assigned to Empire Formation and its Wishkahan Stage (new name). Age changed from early Pliocene to: early late Miocene.

Copley Greenstone

(age changed)

Middle Devonian

nor thwestern California

Irwin, W. P., 1977, Review of Paleozoic rocks of the Klamath Mountains, in Stewart, J. H., Stevens, C. H., and Fritsche, A. E., eds., Paleozoic paleogeography of the western United States, Pacific Coast Paleogeography Symposium 1: Soc. Econ. Paleontologists and Mineralogists, Pacific Sec., p. 441-454. 
Age changed from Devonian(?) to: Middle Devonian.

\author{
Copper Basin Formation \\ Lower and Upper Mississippian \\ south-central Idaho \\ (geographic restriction)
}

Nilsen, T. H., 1977, Paleogeography of Mississippian turbidites in southcentral Idaho, in Stewart, J. H., Stevens, C. H., and Fritsche, A. E., eds., Paleozoic paleogeography of the western United States, Pacific Coast Paleogeography Symposium 1: Soc. Econ. Paleontologists and liineralogists, Pacific Sec., p. 275-299.

Geographically restricted from White Knob Mountains of central Idaho; its rocks now included in McGowan Creek Formation (now geographically extended). Copper Basin remains in good usage in Pioneer Mountains (its type locality).

\author{
Cougar Point Welded Tuff (age changed) \\ upper Miocene \\ nor theastern Nevada
}

Coats, R. R., Green, R. C., Cress, L. D., and Marks, L. Y., 1977, Minera1 resources of the Jarbidge Wilderness and adjacent areas, Elko County, Nevada, with a section on Interpretation of aeromagnetic data by W. E. Davis: U.S. Geol. Survey Bull. 1439, 79 p.

Age changed from Pliocene to: late Miocene; Cougar Point remains in good usage in southern Idaho.

\author{
Counc11 Sandstone Member \\ (of Norton Formation) \\ Lower(?) Pennsylvanian \\ southwestern Virginia
}

Miller, R. L., and Meissner, C. R., Jr., 1977, Geologic map of the Big A Mountain quadrangle, Buchanan and Russell Counties, Virginia: U.S. Geol. Survey Geol. Quad. Map GQ-1350.

Council Sandstone Member adopted and assigned as lower of two members of Norton Formation. Overlies Tiller coal bed and underlies Jawbone coal bed (both in Norton Formation).

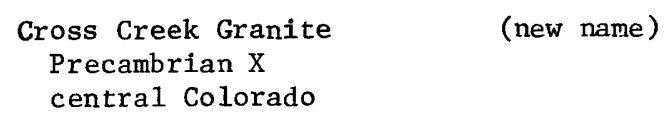

Tweto, Ogden, and Lovering, T. S., 1977, Geology of the Minturn 15-minute quadrangle, Eagle and Summit Counties, Colorado: U.S. Geol. Survey Prof. Paper 956, 96 p. 
Cross Creek Granite adopted. Concordant with enclosing Precambrian X gneisses and having gradational contacts; approximate, if not exact, correlative of Boulder Creek Granite of Front Range area.

Crystal Peak Dolomite (age refinement)

Middle Ordovician

western Utah

Berdan, J. M., 1976, Middle Ordovician leperditicopid ostracodes from the Ibex area, Millard County, western Utah: Brigham Young Univ. Geology Studies, v. 23, pt. 3, p. 37-65.

Age refined from Ordovician to: Middle Ordovician.

Currant Tuff (age changed)

lower 01igocene

eas tern Nevada

Hose, R. K., and Blake, M. C., Jr., 1976, Geology and mineral resources of White Pine County, Nevada--Pt. I, Geology: Nevada Bur. Mines and Geology Bul1. 85, p. 1-35.

Age changed from late Miocene or early Pliocene to: early 0ligocene.

Daguao Formation (new name)

Lower Cretaceous

eastern Puerto Rico

M'Gonigle, J. W., 1977, The Río Abajo, Pitahaya, and Daguao Formations in eastern Puerto Rico: U.S. Geol. Survey Bul1. 1435-B, 10 p.

Daguao Formation adopted. Base not exposed; underlies Figuera Lava.

\author{
Devils Peak Member (name adopted) \\ (of Santa Cruz Island Volcanics) \\ upper 0ligocene to middle Miocene \\ (Saucesian and Relizian) \\ Santa Cruz Island off southern California coast
}

Crowe, B. M., McLean, Hugh, Howe11, D. G., and Higgins, R. E., 1976, Petrography and major-element chemistry of the Santa Cruz Island Volcanics, in Howel1, D. G., ed., Aspects of the geologic history of the California continental borderland: Am. Assoc. Petroleum Geologists Misc. Pub. 24, p. 196-215.

Devils Peak Member of Nolf and Nolf (1969) adopted as one of four members of Santa Cruz Island Volcanics. Overlies Stanton Ranch Member and underlies Prisoners Harbor Member, both of Santa Cruz Island Volcanics. 
Dillsboro Formation

(bed adopted and assigned to)

Upper Ordovician

southeastern Indiana

Swadley, W. C., and Gibbons, A. B., 1976, Geologic map of the Cambellsburg quadrangle, north-central Kentucky: U.S. Geol. Survey Geol. Quad. Map GQ-1364.

Marble Hill Marble of Owen (1859) adopted as Marble Hill Bed of Dillsboro Formation in southeastern Indiana as used by Shaver and others (1970). Geographically extended into north-central Kentucky and reassigned to Rowland Member of Drakes Formation.

Doughnut Shale (geographic extension and name changed)

Upper Mississippian

northwestern Colorado

Hansen, W. R., 1977, Geologic map of the Canyon of Lodore South quadrangle, Moffat County, Colorado: U.S. Geol. Survey Geol. Quad. Map GQ-1403.

Geographically extended from Utah into northwestern Colorado as Doughnut Shale. Doughnut Formation remains good usage in Utah.

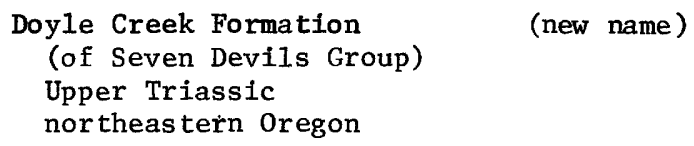

Vallier, T. L., 1977, The Permian and Triassic Seven Devils Group, western Idaho and northwestern Oregon: U.S. Geol. Survey Bul1. 1437, 58 p.

Doyle Creek Formation adopted and assigned as uppermost of four formations to Seven Devils Group (now raised in rank). Includes Kurry Creek Member (new name). Conformably overlies Wild Sheep Creek Form Formation (new name) of Seven Devils; unconformably(?) underlies Martin Bridge Limestone.

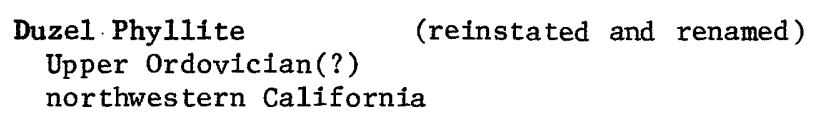

Hotz, P. E., 1977, Geology of the Yreka quadrangle, Siskiyou County, California: U.S. Geol. Survey Bul1. 1436, 72 p. 
Duzel Formation reinstated for its type area and renamed Duzel Phyllite. Conformably(?) overlies Sissel Gulch Graywacke (new name) and, elsewhere, thrust over Gazelle and Moffett Creek (new name) Formations and Schulmeyer Gulch sequence.

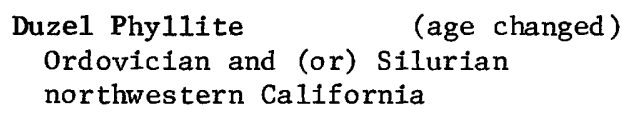

Potter, A. W., Hotz, P. E., and Rohr, D. M., 1977., Stratigraphy and inferred tectonic framework of lower Paleozoic rocks in the eastern Klamath Mountains, northern California, in Stewart, J. H., Stevens, C. H., and Fritsche, A. E., eds., Paleozoic paleography of the western United States, Pacific Coast Paleogeography Symposium 1: Soc. Econ. Paleontologists and Mineralogists, Pacific Sec. p. 421-440.

Age changed from Late Ordovician(?) to: Ordovician and (or) Silurian.

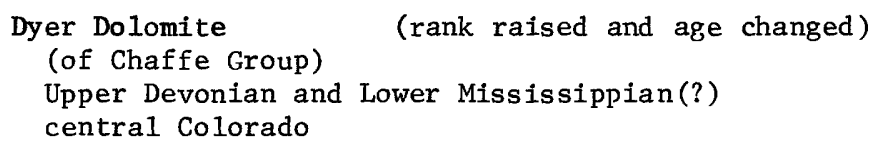

Tweto, Ogden, and Lovering, T. S., 1977, Geology of the Minturn 15-minute quadrangle, Eagle and Summit Counties, Colorado: U.S. Geol. Survey Prof. Paper 956, $96 \mathrm{p}$.

Raised in rank from Dyer Dolomite Member or Dyer Member to: Dyer Dolomite and reassigned as middle formation of Chaffee Group (now raised in rank). Age changed from Late Devonian to: Late Devonian and Early Mississippian(?).

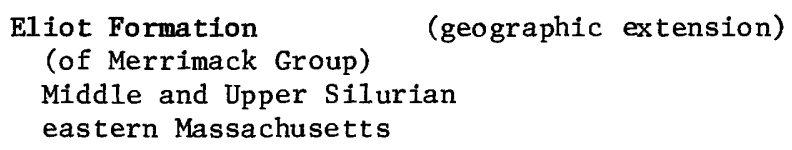

Barosh, P. J., 1976, Stratigraphy of the Webster-Worcester region, Massachusetts, in Geology of southeastern New England--Guidebook, New England Intercollegiate Geo1. Conf., 68 th Ann. Mtg., Boston, Mass.: Princeton, New Jersey, Science Press, p. 352-365.

Geographically extended into eastern Massachusetts from Maine and New Hampshire. 


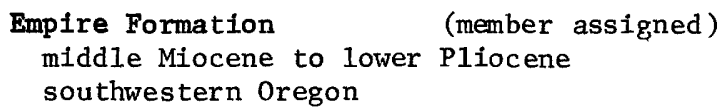

Addicott, W. 0., 1976, Neogene molluscan stages of Oregon and Washington, in Fritsche, A. E., and others, eds., The Neogene Symposium, Pacific Coast of North America, Soc. Econ. Paleontologists and Mineralogists, Pacific Sec., San Francisco, California, April 1976: p. 95-115.

Coos Conglomerate reduced in rank to Coos Conglomerate Member (lower upper Miocene) and assigned to Empire Formation and its Wishkahan Stage (new name).

\section{Endicott Group (name adopted and assigned) \\ Upper Devonian to Upper Mississippian \\ northern Alaska}

Armstrong A. K., and Bird, K. J., 1976, Facies and environments of deposition of Carboniferous rocks, Arctic Alaska, in Miller, T. P., ed., Recent and ancient sedimentary environments in Alaska: Anchorage, Alaska Geo1. Soc. Symposium Proc., p. A1-A16.

In eastern Sadlerochit Mountains, Itkilyariak Formation of Mull and Mangus (1972) adopted as uppermost formation of Endicott Group.

\section{Erving Formation (name and age changed)}

Lower Devonian

Massachusetts

Leo, G. W., Robinson, Peter, and Hall, D. J., 1977, Bedrock geologic map of the Ludlow quadrangle, Hampden and Hampshire Counties, south-central Massachusetts: U.S. Geol. Survey Geol. Quad. Map GO-1353.

Name changed from Erving Hornblende Schist to Erving Formation after Thompson and others (1968). Age changed from pre-Triassic to:

Early Devonian.

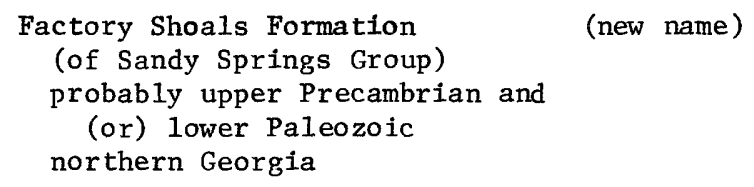

Higgins, M. H., and McConne11, K. I., The Sandy Springs Group and related rocks in the Georgia Piedmont: nomenclature and stratigraphy: this report.

Factory Shoals Formation adopted and assigned as one of four formations to Sandy Springs Group. Overlies Chattahoochee Palisades Quartzite and underlies Rottenwood Creek Quartzite (both of Sandy Springs Group; both new names). 


\author{
Fairport Member \\ (geographic extension) \\ (of Carlile Formation) \\ Upper Cretaceous \\ northeastern New Mexico
}

Pillmore, C. L., and Eicher, D. L., 1976. Lower part of the marine Cretaceous at Gold Creek Vermejo Park, New Mexico, in New Mexico Geol. Soc. Guidebook, 27th Field Conf., Vermejo Park, 1976: p. 171-176.

Geographically extended from Kansas and Colorado into: northeastern New Mexico as lowermost of three named members of Carlile Formation (name changed from Carlile Shale). Overlies Greenhorn Formation (name changed from Greenhorn Limestone or Shale); underlies Blue Hill Shale Member of Carlile (also geographically extended). Fairport Chalk or Chalky Shale Member of Carlile Shale remains in good usage in Kansas and Colorado.

\author{
Fernvale Member (name revised and geographic extension) \\ (of Shellmound Formation) \\ Upper Ordovician \\ southeastern Tennessee and northwestern Georgia
}

Milici, R. C., and Wedow, Helmuth, Jr.,.1977, Upper Ordovician and Silurian stratigraphy in Sequatchie Valley and parts of the adjacent Valley and Ridge Tennessee: U.S. Geo1. Survey Prof., Paper 996, 38 p.

Fernvale Limestone or Formation reduced in rank to Fernvale Member and assigned to upper part of Shellmound Formation (new name) in southeastern Tennessee and northwestern Georgia (geographic extension). Former formation rank remains unchanged elsewhere in Tennessee and in Alabama, Arkansas, Oklahoma, Missouri, and Illinois.

\title{
Finger Bay Volcanics (age changed) \\ Paleocene or lower Eocene \\ southwestern Alaska
}

Hein, J. R., and McLean, Hugh, 1977, Paleogene sedimentary and volcanogenic rocks from Adak Island, central Aleutian Islands, Alaska: Geol. Soc. America Abs. with Programs, v. 9, no. 4, p. 433.

Age changed from early Tertiary to: Paleocene or early Eocene.

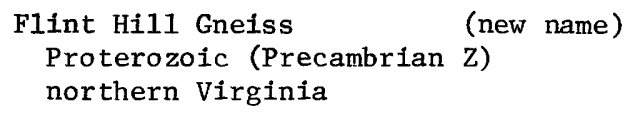

Lukert, M. T., Nuckols, E. B., and Clarke, J. W., 1977, Flint Hill Gneiss-a definition: Southeastern Geology, v. 19, no. 1, p. 19-28. 
Flint Hill Gneiss adopted. Intruded by Robertson River Formation of Allen (1963); contiguous with Marshall Granite of Jonas (1928); juxtaposed with Pedlar Formation of Bloomer and Werner (1955).

\section{Floyds Knob Bed}

(of Muldraugh Member)

(of Borden Formation)

Lower Mississippian

north-central Kentucky and southern Indiana

Kepferle, R. C., 1977, Stratigraphy, petrology, and depositional environment of the Kenwood Siltstone Member, Borden Formation (Mississippian), Kentucky and Indiana: U.S. Geol." Survey Prof. Paper 1007, 49 p.

In north-central Kentucky and southern Indiana, Floyds Knob Formation reduced in rank to Floyds Knob Bed and assigned to basal part of Muldraugh Member of Borden Formation. Floyds Knob Formation usage remains unchanged elsewhere in Kentucky and Indiana.

Fort Logan Formation

lower Míocene

Montana

McGrew, L. W., 1977, Geologic map of the Black Butte Mountain quadrangle, Meagher County, Montana: U.S. Geol. Survey Geol. Quad. Map GQ-1381.

Raised in rank from Fort Logan Beds to: Fort Logan Formation.

\section{Furner Valley Limestone (new name)}

(of Oquirrh Group)

Upper Pennsylvanian and Lower Permian

central Utah

Morris, H. T., Douglass, R. C., and Kopf, R. W., 1977, Stratigraphy and microfaunas of the Oquirrh Group in the southern East Tintic Mountains, Utah: U.S. Geo1. Survey Prof. Paper 1025, 22 p.

Furner Valley Limestone adopted and assigned to Oquirrh Group as uppermost of four formations. Conformably overlies Bingham Mine Formation of Oquirrh; disconformably underlies Diamond Creek Sandstone.

\section{Gazelle Formation (age changed) \\ Lower(?) Silurian to Lower Devonian northwestern California}

Hotz, P. E., 1977, Geology of the Yreka quadrangle, Siskiyou County, California: U.S. Geol. Survey Bull. 1436, 72 p. 
Age changed from Middle and Late Silurian to: Early(?) Silurian to Early Devonian.

\section{Gem Park Complex Middle Cambrian} Colorado

0lson, J. C., Marvin, R. F., Parker, R. L., and Mehnert, H. H., 1977, Age and tectonic setting of lower Paleozoic alkalic and mafic rocks, carbonatites, and thorium veins in south-central Colorado: U.S. Geol. Survey Jour. Research, v. 5, no. 6, p. 673-687.

Age changed from Cambrian to: Middle Cambrian.

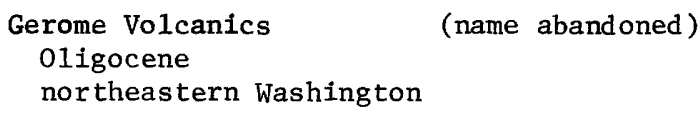

Pearson, R. C., and Obradovich, J. D., 1977, Eocene rocks in northeast Washington--radiometric ages and correlation: U.S. Geo1. Survey Bul1. 1433, $41 \mathrm{p}$.

Gerome Volcanics abandoned; its rocks now included in Sanpoil Volcanics.

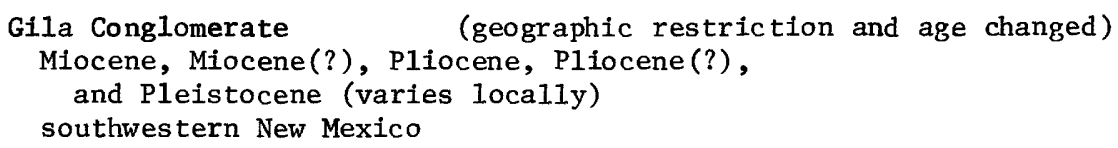

Hedlund, D. C., 1977, Geologic map of the Hillsboro and San Lorenzo quadrangles, Sierra and Grant Counties, New Mexico: U.S. Geol. Survey Misc. Field Studies Map MF-900-A, 2 sheets.

In southwestern New Mexico, geographically restricted as Gila Conglomerate by eastern limit above Mimbres River and in canyons in northwestern part of San Lorenzo quadrangle. Age changed from Pliocene and Pleistocene to: Miocene, Miocene(?), Pliocene, Pliocene(?), and Pleistocene (varies locally). Gila Conglomerate or Formation remains in good usage in southeastern Arizona.

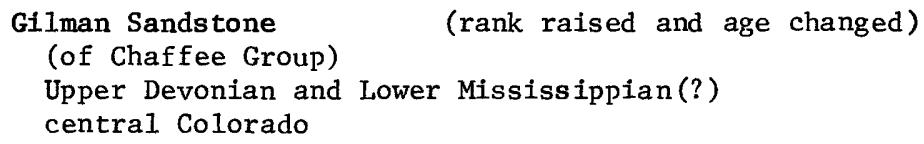

Tweto, Ogden, and Lovering, T. S., 1977, Geology of the Minturn 15-minute quadrangle, Eagle and Summit Counties, Colorado: U.S. Geol. Survey Prof. Paper 956, 96 p. 
Raised in rank from Gilman Sandstone Member of Leadville Limestone or Dolomite to: Gilman Sandstone and reassigned as upper formation of Chaffee Group (now raised in rank). Age changed from Early Mississippiar to: Late Devonian and Early Mississippian(?).

\section{Gladeville Sandstone \\ (age changed)}

Middle Pennsylvanian

southwestern Virginia

Miller, R. L., and Meissner, C. R., Jr., 1977, Geologic map of the Big A Mountain quadrangle, Buchanan and Russell Counties, Virginia: U.S. Geol. Survey Geol. Quad. Map GQ-1350.

Age changed from Pennsylvanian to: Middle Pennsylvanian. Gladeville Sandstone remains good usage in southeastern Kentucky.

\section{Glastonbury Gneiss (age changed) \\ Middle Ordovician to Middle Devonian \\ Massachusetts}

Leo, G. W., Robinson, Peter, and Hall, D. J., 1977, Bedrock geologic map of the Ludlow quadrangle, Hampden and Hampshire Counties, south-central Massachusetts: U.S. Geo1. Survey Geol. Quad. Map G?-1353.

Age changed from Mississippian or Devonian to: Middle Ordovician to Middle Devonian. Glastonbury remains in good usage in Connecticut.

Gods Pocket Dacite (age changed) upper Miocene northeastern Nevada

Coats, R. R., Green R. C., Cress, L. D., and Marks, L. Y., 1977, Mineral resources of the Jarbidge Wilderness and adjacent areas, Elko County, Nevada, with a section on Interpretation of aeromagnetic data by W. E. Davis: U.S. Geol. Survey Bull. 1439, 79 p.

Age changed from Pliocene(?) to: late Miocene.

\section{Graylock Formation (named adopted) \\ Lower Jurassic (Hettangian and Sinemurian?) northeastern Oregon}

Brown, C. E., and Thayer, T. P., 1977, Geologic map of pre-Tertiary rocks in the eastern Aldrich Mountains and adjacent areas to the south, Grant County, Oregon: U.S. Geol. Survey Misc. Geol. Inv. Map I-1021. 
Graylock Formation of Dickinson and Vigrass (1965) adopted. Conformably overlies Rail Cabin Argillite and unconformably underlies Mowich Group (both newly adopted).

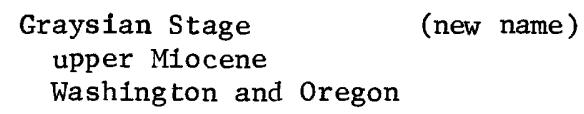

Addicott, W. 0., 1976, Neogene molluscan stages of Oregon and Washington, in Fritsche, A. E., and others, eds., The Neogene Symposium, Pacific Coast of North America, Soc. Econ. Paleontologists and Mineralogists, Pacific Sec., San Francisco, California, April 1976: p. 95-115.

Graysian Stage adopted. Overlies Wishkahan Stage and underlies Moclipsian Stage (both new names).

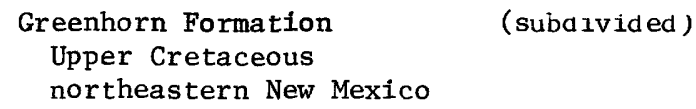

Pillmore, C. L., and Eicher, D. L., 1976. Lower part of the marine Cretaceous at Gold Creek Vermejo Park, New Mexico, in New Mexico Geol. Soc. Guidebook, 27th Field Conf., Vermejo Park, 1976: p. 171-176.

In northeastern New Mexico, Greenhorn Formation (name changed from Greenhorn Limestone or Shale) divided into by geographic extension (ascending): Lincoln, Hartland, and Bridge Creek Limestone Members. Greenhorn Limestone or Shale of Colorado or Benton Group and Greenhorn Limestone or Calcareous Member of Colorado or Benton or Mancos or Cody Shale remain in good usage in Colorado, Kansas, Montana, Nebraska, North and South Dakota, Wyoming, Oklahoma, and elsewhere in New Mexico.

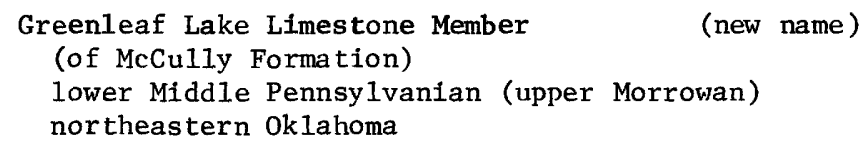

Greenleaf Lake Limestone Member adopted as upper of two named members of McCully Formation (new name). Conformably overlies shale "A" member (informal name) of McCully; underlies shale "B" member (Informal name) of McCully or Atoka Formation. 
Green River Formation

(tongue adopted and assigned)

Eocene only

northwestern Colorado

Hail, W. J., Jr., 1977, Stewart Gulch Tongue-a new tongue of the Eocene Green River Formation, Piceance Creek basin, Colorado: U.S. Geol. Survey Bu11. 1422-E, 8 p.

In northwestern Colorado only, Stewart Gulch Tongue (Eocene) adopted and assigned as uppermost of six named units of Green River Formation. Stewart Gulch overlies Parachute Creek Member of Green River and intertongues with Uinta Formation. Overall age of Green River remains late Paleocene and early and middle Eocene (varies) elsewhere in Colorado and in Utah and Wyoming.

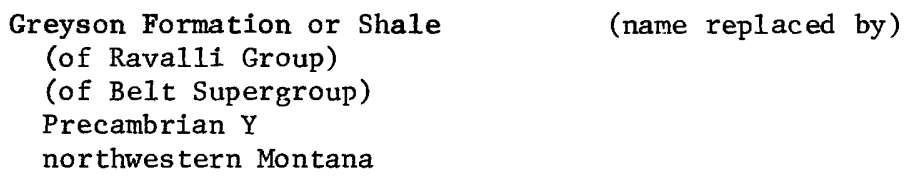

Mudge, M. R., 1977, General geology of Glacier National Park and adjacent areas, Montana: Canadian Soc. Petroleum Geology Bu11., v. 25, no. 4, p. 736-751.

Appekunny Formation abandoned; its rocks replaced by Greyson Formation (or Shale).

\author{
Griffith Canyon Member (name adopted) \\ (of Santa Cruz Island Volcanics) \\ upper 0ligocene to middle Miocene \\ (Saucesian and Relizian) \\ Santa Cruz Island off southern California coast
}

Crowe, B. M., McLean, Hugh, Howell, D. G., and Higgins, R. E., 1976, Petrography and major-element chemistry of the Santa Cruz Island Volcanics, in Howell, D. G., ed., Aspects of the geologic history of the California continental borderland: Am. Assoc. Petroleum Geologists Misc. Pub. 24, p. 196-215.

Griffith Canyon Member of Nolf and Nolf (1969) adopted as lowermost of four members of Santa Cruz Island Volcanics. Overlies in subsurface San Onofre Breccia; underlies Stanton Ranch Member of Santa Cruz Island Volcanics. 


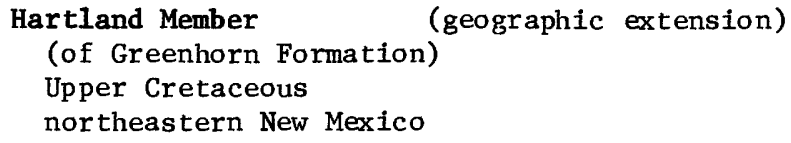

Pillmore, C. L., and Eicher, D. L., 1976. Lower part of the marine Cretaceous at Gold Creek Vermejo Park, New Mexico, in New Mexico Geol. Soc. Guidebook, 27th Field Conf., Vermejo Park, 1976: p. 171-176.

Geographically extended from Kansas and Colorado into: northeastern New Mexico as middle of three members of Greenhorn Formation (name changed from Greenhorn Limestone); overlies Lincoln Member and underlies Bridge Creek Limestone Member (both also geographically extended; both of Greenhorn). Hartland Shale Member of Greenhorn Limestone remains in good usage in Kansas and Colorado.

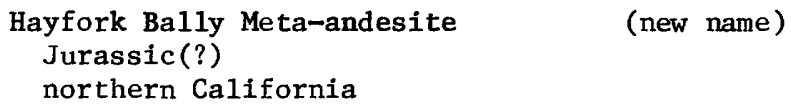

Irwin, W. P., 1977, Review of Paleozoic rocks of the Klamath Mountains, in Stewart, J. H., Stevens, C. H., and Fritsche, A. E., eds., Paleozoic paleogeography of the western United States, Pacific Coast Paleogeography Symposium 1: Soc. Econ. Paleontologists and Mineralogists, Pacific Sec., p. 441-454.

Hayfork Bally Meta-andesite adopted. Intruded by Ironside Mountain batholith and Wildwood pluton; unconformably underlies Weaverville Formation.

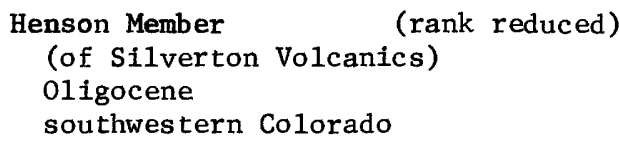

Lipman, P. W., 1976, Geologic map of the Lake City caldera area, western San Juan Mountains, southwestern Colorado: U.S. Geol. Survey Misc. Inv. Map I-962.

Reduced in rank from Henson Formation to: Henson Member; assigned to Silverton Volcanics (now reinstated and reduced in rank).

\author{
Hermit Shale (geographic extension) \\ Lower Permian \\ southeastern Nevada
}

Bohannon, R. G., 1977, Geologic map and sections of the Valley of Fire region, north Muddy Mountains, Clark County, Nevada: U.S. Geo1. Survey Misc. Field Studies Map MF-849.

Geographically extended into southeastern Nevada from Arizona and Utah. 


\section{Hermitage Limestone or Formation (assignment to group) (of Nashville Group) \\ Middle Ordovician \\ Tennessee}

Harris, L. D., and Milici, R. C., 1977, Characteristics of thin-skinned style of deformation in the southern Appalachians and potential hydrocarbon traps: U.S. Geol. Survey Prof. Paper 1018, 40 p.

In Tennessee only, assigned to Nashville Group (now reinstated) as lowermost of four formations. Overlies Carters Limestone; underlies Bigby Limestone (west facies) or $\Leftrightarrow$ Cannon Limestone (east facies) of Nashville. Hermitage Limestone or Formation remains in good usage in Kentucky.

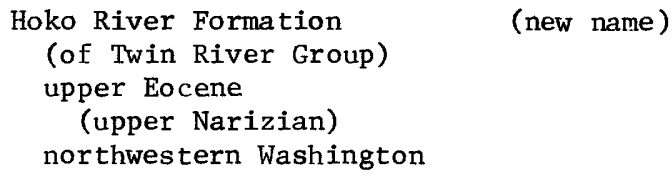

Snavely, P. D., Jr., Niem, A. R., and Pear1, J. E., Twin River Group (upper Eocene to lower Miocene)--defined to include the Hoko River, Makah, and Pysht Formations, Clallam County, Washington: this report.

Hoko River Formation adopted and assigned as lower of three new formations to Twin River Group (now raised in rank). Conformably overlies Lyre Formation; unconformably underlies Makah Formation (new name) of Twin River.

\section{Homerian Stage (age changed) \\ Miocene \\ south-central Alaska}

Triplehorn, D. M., Turner, D. L., and Naeser, C. W., 1977, K-Ar and fission-track dating of ash partings in coal beds from the Kenai Peninsula, Alaska: a revised age for the Homerian Stage-Clamgulchian Stage boundary: Geol. Soc. America Bull., v. 88, no. 8, p. 1156-1160.

Age changed from Miocene and P1iocene(?) to: Miocene.

\section{Humbug Formation (geographic extension) \\ Upper Mississippian \\ northwestern Colorado}

Hansen, W. R., 1977, Geologic map of the Canyon of Lodore South quadrangle, Moffat County, Colorado: U.S. Geo1. Survey Geol. Quad. Map GQ-1403.

Geographically extended from Utah into northwestern Colorado; remains in good usage in northeastern and north-central Utah. 
Humbug Formation

Upper Mississippian

southeastern Idaho

\section{(geographic extension)}

Platt, L. B., 1977, Geologic map of the Ireland Springs-Samaria area, southeastern Idaho and northern Utah: U.S. Geol. Survey Misc. Field Studies Map MF-890.

Geographically extended from Utah and Colorado into southeastern Idaho; remains in good usage in Utah and Colorado.

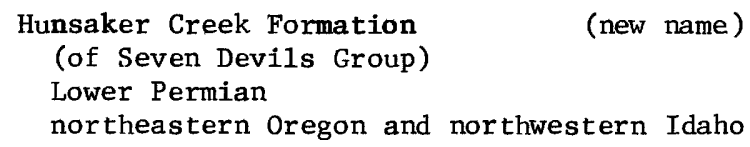

Vallier, T. L., 1977, The Permian and Triassic Seven Devils Group, western Idaho and northwestern Oregon: U.S. Geol. Survey Bul1. 1437, 58 p.

Hunsaker Creek Formation adopted and assigned as one of four formations to Seven Devils Group (now raised in rank). Unconformab1y overlies Windy Ridge Formation and underlies Wild Sheep Creek Formation (both new names of Seven Devils).

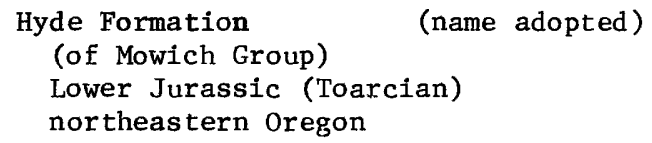

Brown, C. E., and Thayer, T. P., 1977, Geologic map of pre-Tertiary rocks in the eastern Aldrich Mountains and adjacent areas to the south, Grant County, Oregon: U.S. Geol. Survey Misc. Geol. Inv. Map I-1021.

Hyde Formation of Lupher (1941) adopted as uppermost of four formations of Mowich Group as used by Dickinson and Vigrass (1965). Conformably overlies Nicely Formation of Mowich (both newly adopted); conformably and unconformably underlies Snowshoe Formation.

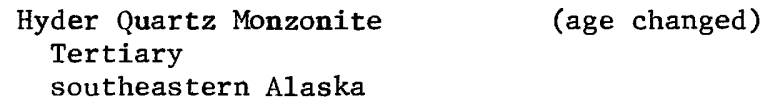

Berg, H. C., Elliott, R. L., Smith, J. G., Pittman, T. L., and Kimba11, A. L., 1977, Mineral resources of the Granite Fiords Wilderness study area, Alaska: U.S. Geo1. Survey Bull. 1403, 151 p. 


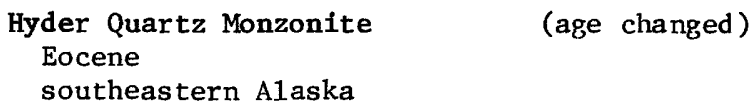

Smith, J. G., 1977, Geology of the Ketchikan D-1 and Bradford Canal A-1 quadrangles, southeastern Alaska: U.S. Geol. Survey Bul1. 1425, 49 p.

Age changed from Tertiary to: Eocene.

\author{
Inman Formation (name adopted) \\ Upper Ordovician \\ southeastern Tennessee and northwestern Georgia
}

Milici, R. C., and Wedow, Helmuth, Jr., 1977, Upper Ordovician and Silurien stratigraphy in Sequatchie Valley and parts of the adjacent Valley and Ridge Tennessee: U.S. Geol. Survey Prof. Paper 996, 38 p.

Inman Formation of Wilson (1949) adopted. Overlies Catheys Limestone; underlies Leipers Limestone.

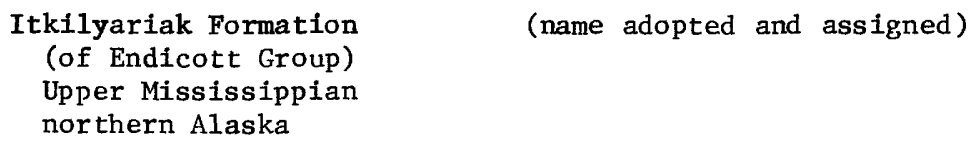

Armstrong A. K., and Bird, K. J., 1976, Facies and environments of deposition of Carboniferous rocks, Arctic Alaska, in Miller, T. P., ed., Recent and ancient sedimentary enviromments in Alaska: Anchorage, Alaska Geol. Soc. Symposium Proc., p. Al-Al6.

Itkilyariak Formation of Mull and Mangus (1972) adopted and assigned to Endicott Group as its uppermost formation. Conformably underlies Alapah Limestone of Lisburne Group.

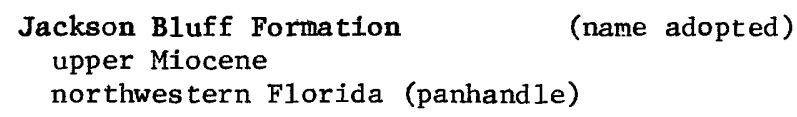

Cameron, C. C., and Mory, P. C., 1977, Minera1 resources of the Bradwell Bay Wilderness and the Sopchoppy River study area, Wakulla County, Florida: U.S. Geol. Survey Bul1. 1431, 37 p.

Jackson B1uff Formation of Puri and Vernon (1964) adopted. Over1ies Hawthorn Formation; underlies Miccosukee Formation. 
Jarbidge Rhyolite

(age changed)

middle Miocene

northeastern Nevada

Coats, R. R., Green, R. C., Cress, L. D., and Marks, L. Y., 1977, Minera1 resources of the Jarbidge Wilderness and adjacent areas, Elko County, Nevada, with a section on Interpretation of aeromagnetic data by W. E. Davis: U.S. Geol. Survey Bull. 1439, 79 p.

Age changed from late Miocene(?) to: middle Miocene.

\title{
Jenny Creek Tuff \\ (age changed)
}

upper Miocene

northeastern Nevada

Coats, R. R., Green R. C., Cress, L. D., and Marks, L. Y., 1977, Mineral resources of the Jarbidge Wilderness and adjacent areas, Elko County, Nevada, with a section on Interpretation of aeromagnetic data by

W. E. Davis: U.S. Geol. Survey Bull. 1439, 79 p.

Age changed from Pliocene to: late Miocene.

\author{
Josephine Peridotite (name adopted) \\ Jurassic or older \\ southwestern Oregon and northwestern California
}

Loney, R. A., and Himmelberg, G. R., 1977, Geology of the gabbroic complex along the northern border of the Josephine Peridotite, Vulcan Peak area, southwestern Oregon: U.S. Geol. Survey Jour. Research, v. 5, no. 6, p. 761-781.

Josephine peridotite sheet of Wells, Hotz, and Cater (1948, 1949) adopted as Josephine Peridotite. Includes rocks previously designated by informal name "Vulcan Peak peridotite," overlies Dothan Formation in thrust contact.

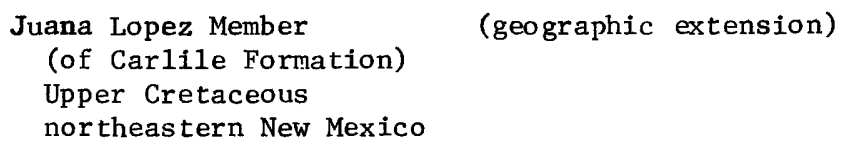

(geographic extension)

Pillmore, C. L., and Eicher, D. L., 1976. Lower part of the marine Cretaceous at Gold Creek Vermejo Park, New Mexico, in New Mexico Geol. Soc. Guidebook, 27th Field Conf., Vermejo Park, 1976: p. 171-176. 
Geographically extended from elsewhere in New Mexico and in Colorado into: northeastern New Mexico as uppermost of three named members of Carlile Formation (name changed from Carlile Shale). Overlies Blue Hill Shale Member of Carlile (also geographically extended); underlies uppermost unnamed black shale unit of Carlile. Juana Lopez Member of Mancos or Carlile Shale remains in good usage in Colorado and elsewhere in New Mexico

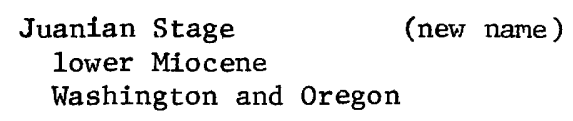

Addicott, W. 0., 1976, Neogene molluscan stages of Oregon and Washington, in Fritsche, A. E., and others, eds., The Neogene Symposium, Pacific Coast of North America, Soc. Econ. Paleontologists and Mineralogists, Pacific Sec., San Francisco, California, April 1976: p. 95-115.

Juanian Stage adopted. Overlies unnamed Oligocene stage; underlies Phillarian Stage (new name).

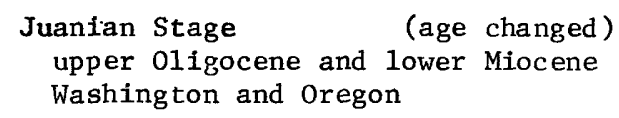

Addicott, W. 0., 1977, Neogene chronostratigraphy of nearshore marine basins of the eastern North Pacific, in Proceedings of the First International Congress on Pacific Neogene stratigraphy, Tokyo, 1976: p. 151-175.

Age changed from early Miocene to: late Oligocene and early Miocene.

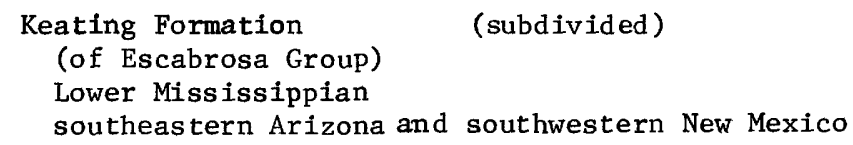

Armstrong, A. K., and Mamet, B. L., The Bugle and Witch Members of the Keating Formation, Escabrosa Group, and the Mississippian nomenclature in the Big Hatchet Mountains, Hidalgo County, New Mexico: this report.

Divided into (ascending): Bugle and Witch Members (both new names). Unconformably overlies Percha Shale; unconformably underlies Hachita Formation. 


\title{
Kialagvik Formation (age changed) \\ Lower and Middle Jurassic (Toarcian and Bajocian) southern Alaska
}

Imlay, R. W., and Detterman, R. L., 1977, Some Lower and Middle Jurassic beds in Puale Bay-Alinchak Bay area, Alaska Peninsula: Am. Assoc. Petroleum Geologists Bu11., v. 61, no. 4, p. 607-611.

Age changed from Middle Jurassic to: Early and Middle Jurassic (Toarcian and Bajocian).

\section{Klondike Mountain Formation (age changed) \\ Eocene \\ northeastern Washington}

Pearson, R. C., and Obradovich, J. D., 1977, Eocene rocks in northeast Washington--radiometric ages and correlation: U.S. Geo1. Survey Bull. 1433, $41 \mathrm{p}$.

Age changed from O1igocene and Miocene(?) to: Eocene.

\author{
Knox Group (subdivided) \\ Upper Cambrian and Lower Ordovician \\ southwestern Virginia
}

Miller, R. L., and Meissner, C. R., Jr., 1977, Geologic map of the Big A Mountain quadrangle, Buchanan and Russell Counties, Virginia: U.S. Geol. Survey Geol. Quad. Map GQ-1350.

In southwestern Virginia only, divided into (ascending): Copper Ridge Dolomite (including Chances Branch Dolomite Member of Maynardville Limestone at base, undivided) and Beekmantown Dolomite. Knox Group or Dolomite remains good usage in Tennessee, Alabama, Georgia, North Carolina, Kentucky, and other parts of Virginia.

\section{Kobeh Member (name adopted) \\ (of McColley Canyon Formation) \\ Lower Devonian \\ central Nevada}

Berdan, J. M., ]977, Early Devonian ostracode assemblages from Nevada, in Murphy, M. A. and others, eds., Nestern North America: Devonian: Riverside, Calif., Univ. California, Riverside Campus Museum Contrib. no. 4, p. 55-64.

Kobeh Member of Murphy and Gronberg (1970) adopted as lowermost of three members of McColley Canyon Formation. Overlies Lone Mountain Dolomite; underlies Bartine Member of McColley Canyon. 


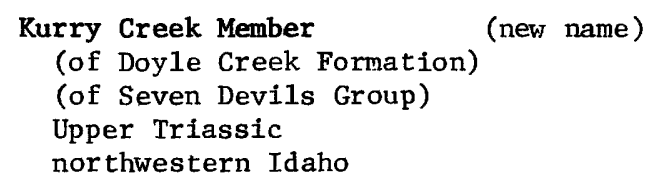

Vallier, T. L., 1977, The Permian and Triassic Seven Devils Group, western Idaho and northwestern Oregon: U.S. Geol. Survey Bul1. 1437, 58 p.

Kurry Creek Member adopted and assigned to Doyle Creek Formation (new name) of Seven Devils Group (now raised in rank). Locally underlies Martin Bridge Limestone.

\section{Lago Garzas Formation Upper Cretaceous and Eocene \\ Puerto Rico}

Krushensky, R. D., and Curet, A. F., 1977, Unconformity between the Late Cretaceous and early Tertiary in western Puerto Rico-a concept rejected, in Geological Survey research 1977: U.S. Geo1. Survey Prof. Paper 1050, p. 91 .

Age changed from Late Cretaceous to: Late Cretaceous and Eocene.

Lawler Peak Granite (age refinement)

Precambrian $\mathrm{Y}$

Arizona

Ludwig, K. R., and Silver, L. T., 1977, Lead-isotope inhomogeneity in Precambrian igneous K-feldspars: Geochim. Cosmochim. Acta, v. 41, no. 10, p. 1456-1471.

Age changed from Precambrian to: Precambrian Y.

\section{Leadville Limestone or Dolomite (name revised)} Lower and Upper Mississippian central Colorado

Tweto, Ogden, and Lovering, T. S., 1977, Geology of the Minturn 15-minute quadrangle, Eagle and Summit Counties, Colorado: U.S. Geol. Survey Prof. Paper 956, 96 p.

In central Colorado only, stratigraphically restricted to beds above Gilman Sandstone. Gilman Sandstone Member removed from Leadville, raised to formation rank, and reassigned to Chaffee Group (now raised in rank). Leadville usage remains unchanged in Arizona and New Mexico and elsewhere in Colorado. 


\author{
Ledger Dolomite (age changed) \\ Middle Cambrian \\ southeastern Pennsylvania
}

Gohn, G. S., Revised ages of Cambrian and Ordovician formations of the Conestoga Valley near York and Lancaster, southeastern Pennsylvania: this report.

Age changed from Early Cambrian to: Middle Cambrian. Remains good usage elsewhere in Pennsylvania and in Virginia.

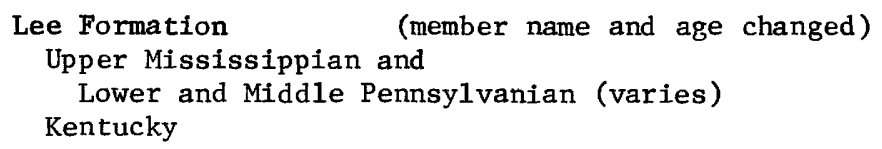

Rice, C. L., Ages of the Lee, Breathitt, Caseyville, Tradewater, and Sturgis Formations in Kentucky: this report.

Names of its Rockcastle Sandstone or Conglomerate Member (above) and its Livingston Conglomerate Member (below) changed to: Rockcastle Sandstone Tongue and Livingston Conglomerate Tongue (both intertonguing with Breathitt Formation) in Pottsville escarpment area of eastern Kentucky only; former usage as Members of Lee remains unchanged elsewhere in Kentucky. Age of its Rockcastle changed from Early Pennsyvanian (Morrowan) to: Early and Middle Pennsylvanian (early and late Morrowan). Lee usage remains unchanged in Virginia and Tennessee.

\author{
Leesburg Limestone Conglomerate Member (new name) \\ (of Bull Run Formation) \\ (of Newark Group) \\ Upper Triassic \\ north-central Virginia and south-central Maryland
}

Lee, K. Y., 1977; Triassic stratigraphy in the northern part of the Culpeper basin, Virginia and Maryland: U.S. Geol. Survey Bul1. 1422-C, $17 \mathrm{p}$.

Leesburg Limestone Conglomerate Member adopted as lower of two members of Bull Run Formation of Newark Group. Overlies Balls Bluff Siltstone (new name) of Newark; underlies unnamed basaltic flow-bearing clastics member of Bull Run.

\author{
Lennep Sands tone Member \\ (of Sedan Formation) \\ (of Livingston Group) \\ Upper Cretaceous \\ south-centra1 Montana
}

(rank reduced) 
Skipp, Betty, and McGrew, L. W., 1977, The Maudlow and Sedan Formations of the Upper Cretaceous Livingston Group on the west edge of the Crazy Mountains basin, Montana: U.S. Geol. Survey Bull. 1422-B, 68 p.

In Sedan-Ringling area of south-central Montana, reduced in rank from Lennep Sandstone to: Lennep Sandstone Member and reassigned as uppermost Member of Sedan Formation (new name) of Livingston Group. Overlies Bearpaw Shale Member (also reduced in rank) of Sedan; underlies Billman Creek Formation of Livingston. Usage of Lennep Sandstone of Montana Group remains unchanged elsewhere in Montana.

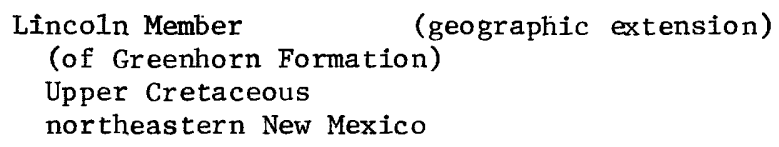

Pillmore, C. L., and Eicher, D. L., 1976. Lower part of the marine Cretaceous at Gold Creek Vermejo Park, New Mexico, in New Mexico Geol. Soc. Guidebook, 27th Field Conf., Vermejo Park, 1976: p. 171-176.

Geographically extended from Kansas and Colorado into: northeastern New Mexico as lowermost of three members of Greenhorn Formation (name changed from Greenhorn Limestone); underlies Hartland Member of Greenhorn (also geographically extended). Lincoln Limestone Member of Greenhorn Limestone remians in good usage in Kansas and Colorado.

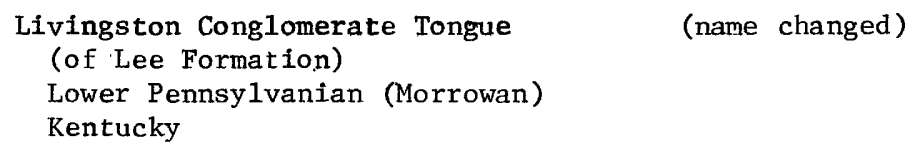

Name changed from Livingston Conglomerate Member to: Livingston Conglomerate Tongue (intertonguing with Breathitt Formation) in Pottsville escarpment area of eastern Kentucky only; former usage as Member remains unchanged elsewhere in Kentucky.

\section{Livingston Group (subdivided)}

Upper Cretaceous

south-central Montana

Skipp, Betty, and McGrew, L. W., 1977, The Maudlow and Sedan Formations of the Upper Cretaceous Livingston Group on the west edge of the Crazy Mountains basin, Montana: U.S. Geol. Survey Bull. 1422-B, 68 p. 
Divided into (ascending): in Sedan-Ringling area, Sedan Formation (new name with its (ascending) unnamed lower sandstone, welded tuff, middle sandstone, and mudstone members and Bearpaw Shale and Lennep Sands tone Members (both reduced in rank)) and Billman Creek Formation; in Maudlow area, Maudlow Formation only. Livingston usage remains unchanged elsewhere in Montana.

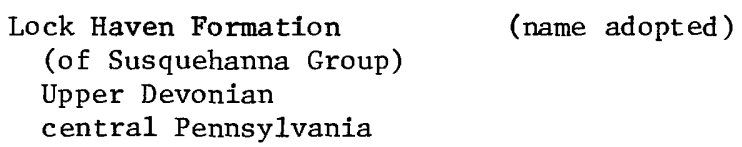

Taylor, A. R., 1977, Geology and mineral resources of the Lock Haven 7-1/2-minute quadrangle, Clinton and Lycoming Counties, Pennsylvania: Pennsylvania Topog. and Geol. Survey Atlas 124a.

Lock Haven Formation of Faill and others (1977) adopted and assigned as one of four formations to Susquehanna Group; replaces part or most of rocks formerly included in Chemung Formation (now abandoned in Pennsylvania). Overlies Brallier Formation and underlies Catskill Formation, both of Susquehanna Group.

\section{Lone Mountain Dolomite (age changed) \\ Upper Silurian and Lower Devonian \\ Nevada}

Smith, J. F., Jr., and Ketner, K. B., 1977, Tectonic events since early Paleozoic in the Carlin-Pinon Range area, Nevada: in Geology of the Carlin-Pinon Range area, Nevada: U.S. Geol. Survey Prof. Paper 867-C, p. $\mathrm{Cl}-\mathrm{C} 18$.

Age changed from Late Silurian to: Late Silurian and Early Devonian.

Long Island Creek Gneiss (new name) probably upper Precambrian and

(or) lower Paleozoic northern Georgia

Higgins, M. H., and McConne11, K. I., The Sandy Springs Group and related rocks in the Georgia Piedmont: nomenclature and stratigraphy: this report.

Long Island Creek Gneiss adopted; in fault contact with adjacent rocks (so stratigraphic position is unknown). 


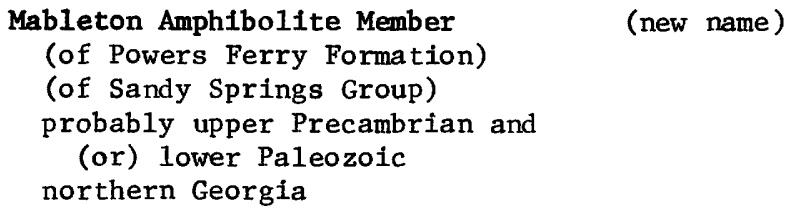

Higgins, M. H., and McConnell, K. I., The Sandy Springs Group and related rocks in the Georgia Piedmont: nomenclature and stratigraphy: this report.

Mableton Amphibolite Member adopted and assigned to Powers Ferry Formation (new name) of Sandy Springs Group.

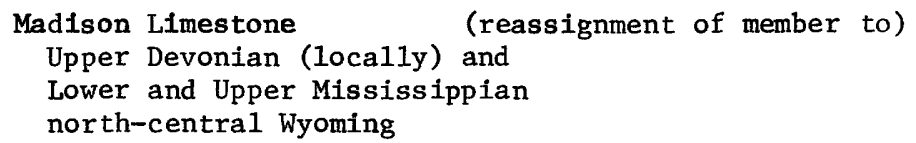

Sando, W. J., 1975, Stratigraphic sections of the Madison Limestone and Amsden Formation, west flank of the Bighorn basin, Wyoming, in Wyoming Geol. Assoc. Guidebook, 27 th Ann. Field Conf., Bighorn Basin, 1975: p. 129-137.

In north-central Wyoming only, Woodhurst Member reassigned as member of Madison Limestone; Woodhurst remains member of Lodgepole Limestone of Madison Group in Montana and Idaho and elsewhere in Wyoming. Usage of Madison Limestone or Formation or Group remains unchanged in Montana, Colorado, Utah, Idaho, and South Dakota and elsewhere in Wyoming.

\section{Mahantango Formation}

Middle Devonian

central Pennsylvania

\section{(subdivided)}

Taylor, A. R., 1977, Geology and mineral resources of the Lock Haven 7-1/2-minute quadrangle, Clinton and Lycoming Counties, Pennsylvania: Pennsylvania Topog. and Geol. Survey Atlas 124a.

In report area, divided into (ascending): unnamed shale member and Tully Limestone Member (reduced in rank). Mahantango usage remains unchanged elsewhere in Pennsylvania, Maryland, and West Virginia.

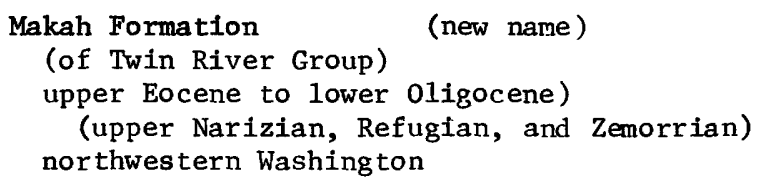

Snavely, P. D., Jr., Niem, A. R., and Pearl, J. E., Twin River Group (upper Eocene to lower Miocene)-defined to include the Hoko River, Makah, and Pysht Formations, Clallam County, Washington: this report. 
Makah Formation adopted and assigned as middle of three new formations to Twin River Group (now raised in rank). Unconformably overlies Hoko River Formation (new name) of Twin River; gradationally and, locally, unconformably underlies Pysht Formation (new name) of Twin River.

\author{
Manassas Sandstone (name adopted) \\ (of Newark Group) \\ Upper Triassic \\ north-central Virginia and south-central Maryland
}

Lee, K. Y., 1977, Triassic stratigraphy in the northern part of the Culpeper basin, Virginia and Maryland: U.S. Geol. Survey Bull. 1422-C, $17 \mathrm{p}$.

Manassas Sandstone of Roberts (1923) adopted and assigned to Newark Group as lowermost of three formations. Divided into (ascending): Reston Member (new name) and unnamed sandstone member. Underlies Balls Bluff Siltstone (new name) of Nergark.

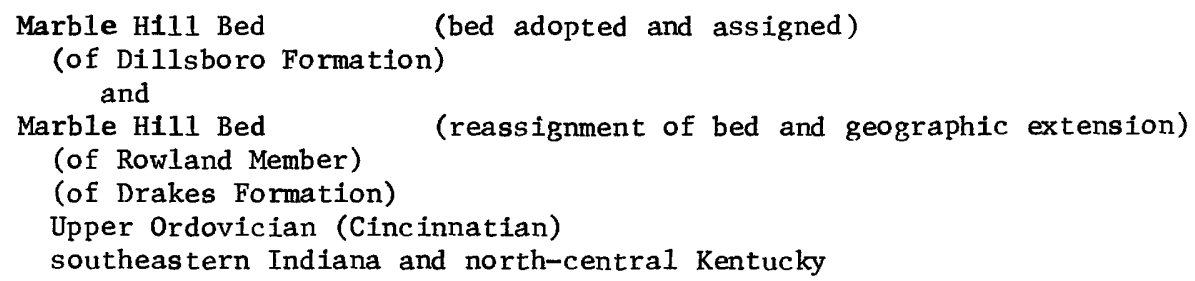

Swadley, W. C., and Gibbons, A. B., 1976, Geologic map of the Cambellsburg quadrangle, north-central Kentucky: U.S. Geol. Survey Geol. Quad. Map GQ-1364.

Marble Hill Marble of Owen (1859) adopted as Marble Hill Bed of Dillsboro Formation in southeastern Indiana as used by Shaver and others (1970). Geographically extended into north-central Kentucky and reassigned to Rowland Member of Drakes Formation.

\author{
Martin Bridge Limestone \\ (name changed and geographic extension) \\ Upper Triassic \\ northeastern Oregon, western Idaho, and \\ southeastern Washington
}

Vallier, T. L., 1977, The Permian and Triassic Seven Devils Group, western Idaho and nor thwestern Oregon: U.S. Geol. Survey Bul1. 1437, 58 p.

Name changed everywhere from Martin Bridge Formation or Limestone to: Martin Bridge Limestone. Geographically extended from northeastern Oregon and western Idaho into: southeastern Washington. 


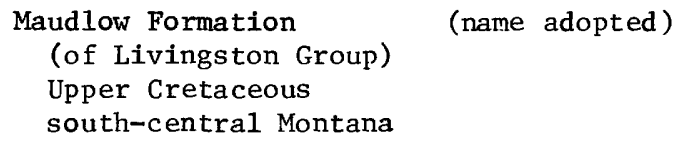

Skipp, Betty, and McGrew, L. W., 1977, The Maudlow and Sedan Formations of the Upper Cretaceous Livingston Group on the west edge of the Crazy Mountains basin, Montana: U.S. Geo1. Survey Bull. 1/22-B, 68 p.

Maudlow Conglomerate Lentil of McMannis (1955) adopted, raised in rank, and redefined as Maudlow Formation and assigned to Livingston Group in Maudlow area, Montana. Overlies Eagle Sandstone or Telegraph Creek Formation; underlies Dunbar Creek Formation or Quaternary gravel.

\section{Maywood Formation (geographic extension) Middle and Upper Devonian (varies) \\ Montana and northern Wyoming}

Sandberg, C. A., and Poole, F. G., 1977, Conodont biostratigraphy and depositional complexes of Upper Devonian cratonic platform and continental shelf rocks in the Western United States, in Murphy, M. A., and others, eds Western North America: Devonian: Riverside, Calif., Univ. California, Riverside Campus Museum Contrib. no. 4, p. 144-182.

Geographically extended from Montana into: northern Wyoming.

\section{McClure Mountain Complex (age refinement) \\ Middle Cambrian}

Colorado

0lson, J. C., Marvin, R. F., Parker, R. L., and Mehnert, H. H., 1977, Age. and tectonic setting of lower Paleozoic alkalic and mafic rocks, carbonatit and thorium veins in south-central Colorado: U.S. Geol. Survey Jour. Research, v. 5, no. 6, p. 673-687.

Age changed from Cambrian to: Middle Cambrian.

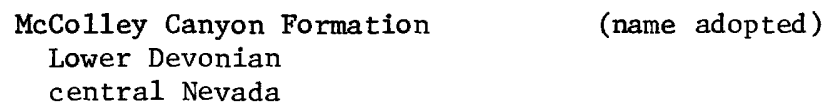

Berdan, J. M., ]977, Early Devonian ostracode assemblages from Nevada, in Murphy, M. A. and others, eds., Western North America: Devonian: Riverside, Calif., Univ. California, Riverside Campus Museum Contrib. no. 4, p. 55-64.

McCo1ley Canyon Member of Carlisle and others (1957) herein adopted as raised in rank to McColley Canyon Formation by Johnson (1962) and as divided into three members (ascending: Kobeh, Bartine, and Coils Creek) by Murphy and Gronberg (1970). 


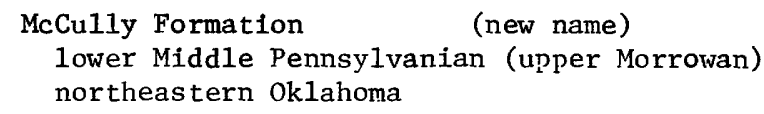

Sutherland, P. K., and Henry, T. W., 1977, Carbonate platform facies and new stratigraphic nomenclature of the Morrowan Series (Lower and Middle Pennsylvanian), northeastern Oklahoma: Geol. Soc. America Bull., v. 88, no. 3, p. 425-4/4n.

McCully Formation adopted as upper of two formations in l.forrowan Provincial Series. Divided into (ascending): Chisum Ouarry Member (new name), shale "A" member, Greenleaf Lake Limestone Member (new name), and shale "B" member. Unconformably overlies Sausbee Formation (new name); unconformably underlies Atoka Formation.

\section{McGowan Creek Formation \\ (geographic extension)}

Lower and Upper Mississippian

east-central Idaho

Nilsen, T. H., 1977, Paleogeography of Mississippian turbidites in southcentral Idaho, in Stewart, J. H., Stevens, C. H., and Fritsche, A. E., eds., Paleozoic paleogeography of the western United States, Pacific Coast Paleogeography Symposium 1: Soc. Econ. Paleontologists and Mineralogists, Pacific Sec., p. 275-299.

Geographically extended into White Knob Mountains of central Idaho, replacing Copper Basin Formation (now geographically restricted).

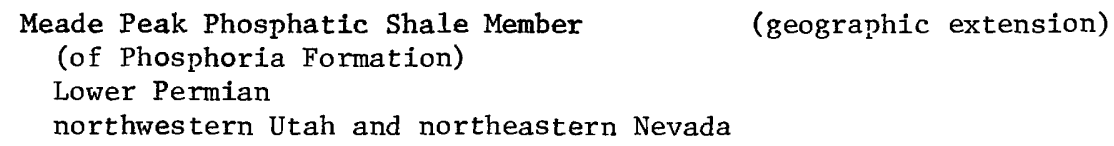

Maughan, E. K., 1977, Petroleum source beds and trace elements in the Phosphoria Formation of Utah and Nevada, in Geological Survey research 1977: U.S. Geol. Survey Prof. Paper 1050, p. 21.

Geographically extended into northisestern Utah and northeastern Nevada. Meade Peak Phosphatic Shale Member or Tongue remains good usage in Idaho, Montana, Wyoming and northeastern Utah.

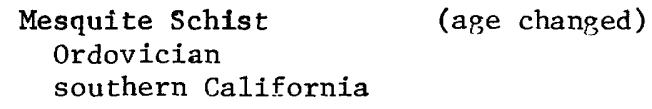

Poole, F. G., Marvin, R. F., and Hedge, C. E., 197.7, Age of the Mesquite Schist in southern California, in Geological Survey research 1977: U.S. Geo1. Survey Prof. Paper $\overline{1050}$, p. 71-72.

Age changed from Precambrian(?) to: Ordovician. 


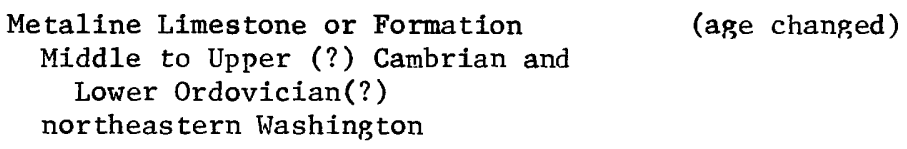

Repetski, J. E., Age of the Metaline Limestone or Formation in northeastern Washington: this report.

Age changed from Middle Cambrian to: Middle to Late(?) Cambrian and Early Ordovician(?).

Miccosukee Formation (name adopted)

upper Miocene

northwestern F1orida (panhandle)

Cameron, C. C., and Mory, P. C., 1977, Mineral resources of the Bradwell Bay Wilderness and the Sopchoppy River study area, Wakulla County, Florida: U.S. Geol. Survey Bul1. 1431, 37 p.

Miccosukee Formation of Puri and Vernon (1964) adopted. Dverlies Jackson Bluff, Hawthorn, and St. Marks Formations; underlies Pleistocene sands.

Middle Canyon Formation (age changed)

Lower and Upper Mississippian

south-centra1 Idaho

Sandberg, C. A., and Poole, F. F., 1977, Conodont biostratigraphy and depositional complexes of Upper Devonian cratonic-platform and continental shelf rocks in the Western United States, in Murphy, M. A., and others, eds Western North America: Devonian: Riverside, Calif., Univ. California, Riverside Campus Museum Contrib. no. 4, p. 144-182.

Age changed from Late Mississippian to: Early and Late Mississippian.

\author{
Moclipsian Stage (new name) \\ P1iocene \\ Washington and oregon
}

Addicott, W. 0., 1976, Neogene molluscan stages of Oregon and Washington, in Fritsche, A. E., and others, eds., The Neogene Symposium, Pacific Coast of North America, Soc. Econ. Paleontologists and Mineralogists, Pacific Sec., San Francisco, California, Apri1 1976: p. 95-115.

Moclipsian Stage adopted. Overlies Graysian Stage (nerg name). 
Moenave Formation

Upper Triassic(?)

(geographic extension)

southeastern Nevada

Bohannon, R. G., 1977, Geologic map and sections of the Valley of Fire region, north Muddy Mountains, Clark County, Nevada: U.S. Geol. Survey Misc. Field Studies Map MF-849.

Geographically extended into southeastern Nevada from Arizona and Utah.

\author{
Moffett Creek Formation (nery name) \\ Silurian or older \\ northwestern California
}

Hotz, P. E., 1977, Geology of the Yreka quadrangle, Siskiyou County, California: U.S. Geol. Survey Bull. 14.36, 72 p.

Moffett Creek Formation adopted. In thrust contact with overlying Sissel Gulch Graywacke (new name) and Duzel Phyllite (now reinstated) and in thrust contact with underlying Duzel Phyllite and Schulmeyer Gulch sequence.

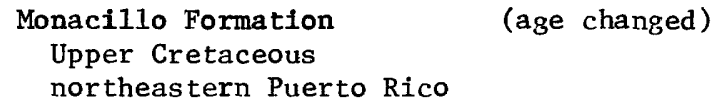

Pease, M. H., Jr., and Monroe, W. H., 1977, Geologic map of the San Juan quadrangle, Puerto Rico: U.S. Geo1. Survey Misc. Geo1. Inv. Map I-1010.

Age changed from Late Cretaceous and early Tertiary(?) to: Late Cretaceous.

Mount Pomeroy Quartz Monzontte (age changed)

Paleocene(?) and Eocene(?)

Colorado

Sharp, W. N., 1976, Geologic man and detalls of the bery11ium and molybdenum occurrences, Mount Antero, Colorado: U.S. Geol. Survey Misc. Field Studies Map MF-819, 2 sheets.

Age changed from Paleocene(?) to Oligocene(?) to: Paleocene(?) and Eocene(?).

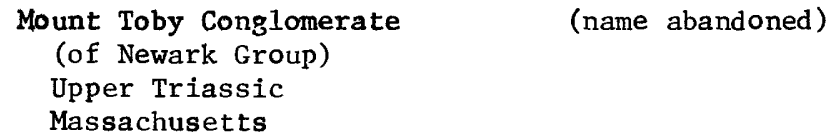

Peper, J. D., 1977, Bedrock geologic map of the Hampden quadrangle, Massachusetts and Connecticut: U.S. Geol. Survey Geol. Ouad. Map G?-1368. 
Mount Toby Conglomerate abandoned; its rocks now included in Portland Formation (of Newark Group).

\author{
Mowich Group (name adopted) \\ Lower Jurassic (P1iensbachian and Toarcian) \\ northeas tern Oregon
}

Brown, C. E., and Thayer, T. P., 1977, Geologic map of pre-Tertiary rocks in the eastern Aldrich Mountains and adjacent areas to the south, Grant County, Oregon: U.S. Geol. Survey Misc. Geol. Inv. Map I-1021.

Mowitch (spelling incorrect) Formation of Davis (1937) adopted as Mowich Group as redefined by Lupher (1941) and Dickinson and Vigrass (1965). Divided into (ascending): Robertson, Suplee, Nicely, and Hyde Formations (a11 four newly adopted). Unconformably overlies older liesozoic rocks; conformably and unconformably underlies Snowshoe Formation.

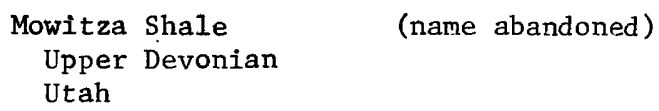

Sandberg, C. A., and Poole, F. G., 1977, Conodont biostratigraphy and depositional complexes of Upper Devonian cratonic-platform and continental shelf rocks in the Western United States, in Murphy, M. A., and others, eds., Western North America: Devonian: Riverside, Calif., Univ. California, Riverside Campus Museum Contrib. no. 4, p. 144-182.

Mowitza Shale abandoned; its rocks now included in part of upper member of Pinyon Peak Limestone.

\title{
Muldraugh Member
}

(of Borden Formation)

(assignment of bed)

Lower Mississippian

north-central Kentucky and southern Indiana

Kepferle, R. C., 1977, Stratigraphy, petrology, and depositional environment of the Kenwood Siltstone Member, Borden Formation (Mississippian), Kentucky and Indiana: U.S. Geol. Survey Prof. Paper 1007, 49 p.

In north-central Kentucky and southern Indiana, Floyds Knob Formation reduced in rank to Floyds Knob Bed and assigned to basal part of Muldraugh Member of Borden Formation. Muldraugh usage elsewhere in Kentucky and Indiana remains unchanged. 


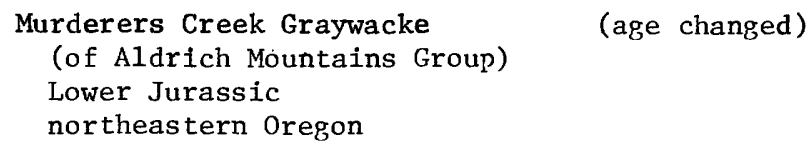

Brown, C. E., and Thayer, T. P., 1977, Geologic map of pre-Tertiary rocks in the eastern Aldrich Mountains and adjacent areas to the south, Grant County, Oregon: U.S. Geol. Survey Ilisc. Geol. Inv. Map I-1021.

Age changed from Late Triassic to: Early Jurassic.

Narrangansett Pier Granite (age changed)

upper Paleozoic

Rhode Island and Connecticut

Goldsmith, Richard, Zietz, Isadore, and Dixon, H. R., 1977, Correlation of aeroradioactivity and geology in southeastern Connecticut and adjacent Rhode Island and New York: Geol. Soc. America Bull., v. 83, no. 7, p. 925-934.

Age changed from Late or post-Pennsylvanian to: late Paleozoic.

Nashville Group (reinstated and subdivided)

Middle Ordovician

Tennessee

Harris, L. D., and Milici, R. C., 1977, Characteristics of thin-skinned style of deformation in the southern Appalachians and potential hydrocarbon traps: U.S. Geol. Survey Prof. Paper 1018, 40 p.

Nashville Group reinstated based on usage of State of Tennessee (after Wilson, 1949). Divided into (ascending): Hermitage Limestone or

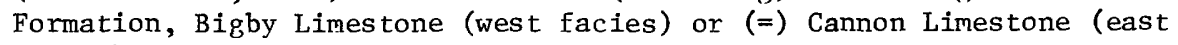
facies), and Catheys Limestone or Formation.

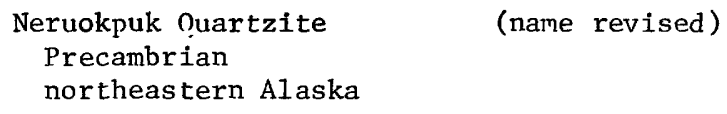

Reiser, H. N., Norrïs, D. K., Dutro, J. T., Jr., and Brosge', W. P., Restriction and renaming of the Neruokpuk Formation, northeastern Alaska: this report.

Usage of Neruokpuk Formation returned to original (stratigraphically restricted) usage of Leffingwell (1919) as Neruokpuk Quartzite. Age changed'from Precambrian, Cambrian, and post-Cambrian pre-Mississippian to: Precambrian. 


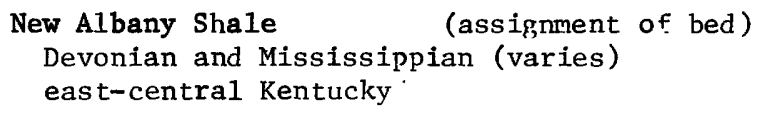

Provo, L. J., Kepferle, R. C., and Potter, P. E., 1977, Three Lick Bed: useful stratigraphic marker in Upper Devonian shale in eastern Kentucky and adjacent areas of Ohio, West Virginia, and Tennessee: U.S. Dept. Commerce, Nat1. Tech. Inf. Service, ERDA-MERC/CR-77-2, 56 p.

Three Lick Bed adopted and assigned to: 1) Ohio Shale in northeastern Kentucky, Ohio, and West Virginia; 2) New Albany Shale in east-central Kentucky (correlates with lower part of Camp Run Member, of local usage, of New Albany in Indiana); and 3) Chattanooga Shale in south-central Kentucky (correlates with middle unit of Gassaway Member of Chattanooga in Tennessee). New Albany usage remains unchanged in Indiana and Illinois.

Newark Group (age changed)

Upper Triassic and Lower Jurassic

Massachusetts and Connecticut

Leo, G. W., Robinson, Peter, and Hall, D. J., 1977, Bedrock geologic map of the Ludiow quadrangle, Hampden and Hampshire Counties, south-central Massachusetts: U.S. Geol. Survey Geol. Quad. Map Gn-1353.

In Massachusetts and Connecticut where its Portland Formation of Newark.Group is Early Jurassic in age, age of Newark changed from Late Triassic to: Late Triassic and Early Jurassic. Newark remains in good usage in New Jersey, New York, Pennsylvania, Maryland, Virginia, Rhode Island, and North Carolina.

\section{Newark Group (its formation abandoned and replaced) \\ Upper Triassic and Lower Jurassic \\ Massachusetts}

Peper, J. D., 1977, Bedrock geologic map of the Hampden quadrangle, Massachusetts and Connecticut: U.S. Geol. Survey Geol. Quad. Map GQ-1368.

In Massachusetts only, its Mount Toby Conglomerate abandoned; Mount Toby rocks now included in its Portland Formation (Lower Jurassic). Newark usage remains unchanged elsewhere.

\section{Newark Group (subdivided)}

Upper Triassic and Lower Jurassic(?)

north-central Virginia and south-central Maryland

Lee, K. $Y_{n}, 1977$, Triassic stratigraphy in the northern part of the Culpeper basin, Virginia and laryland: U.S. Geol. Survey Bull. 1422-C, $17 \mathrm{p}$. 
In Culpeper basin of north-central Virgiria and south-central Maryland, divided into (ascending): Manassas Sandstone and its Reston Member (new name) and overlying unnamed sandstone member, Balls Bluff Siltstone (new name), and Bull Run Formation and its Leesburg, Limestone Conglomerate Member and overiying unnamed basaltic flow-bearing clastics member. Age in Culpeper basin is considered to be Late Triassic and Early Jurassic(?); age elsewhere remains Late Triassic and Early Jurassic. Newark usage elsewhere remains unchanged.

\section{Newportian Stage (new name) \\ middle Miocene \\ Washington and Oregon}

Addicott, W. 0., 19'76, Neogene molluscan stages of Oregon and Nashington, in Fritsche, A. E., and others, eds., The Neogene Symposium, Pacific Coast of North America, Soc. Econ. Paleontologists and Mineralogists, Pacific Sec., San Francisco, California, April 1976: p. 95-115.

Newportian Stage adopted. Overlies Pillarian Stage and underlies Wishkahan Stage (both reiv names).

\section{Newportian Stage (age changed) \\ lower and midile Miocene \\ Washington and Oregon}

Addicott, W. 0., 1977, Neogene chronostratigraphy of nearshore marine basins of the eastern North Pacific, in Proceedings of the First International Congress on Pacific Neogene stratigraphy, Tokyo, 1976: p. 151-175.

Age changed from middle Miocene to: early and middle Miocene.

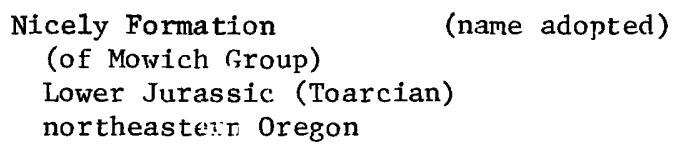

Brown, C. E., and Thayer, T. P., 1977, Geologic map of pre-Tertiary rocks in the eastern Aldrich Mountains and adjacent areas to the south, Grant County, Oregon: U.S. Geol. Survey Misc. Geol. Inv. Map I-1021.

Nicely Shale of Lupher (1941) adopted as Nicely Formation, one of four formations of Mowich Group as used by Dickinson and Vigrass (1965). Conformably overlies Suplee Formation and conformably underlies Hyde Formation, both of Mcwich (all three also newly adopted). 
NLobrara Member

(reassignment)

(of Cody Shale)

Upper Cretaceous

western part of Powder River basin, Wyoming

Merewether, E. A., Cobban, W. A., Matson, R. M., and Magathan, W. J., 1977, Stratigraphic diagrams with electric logs of Upper Cretaceous rocks, Powder River basin, Natrona, Campbel1, and Weston Counties, Wyoming. Section B-B': U.S. Geol. Survey Oil and Gas Inv. Chart OC-74.

Sage Breaks and overlying Niobrara members reassigned to base of Cody Shale in western part of Powder River basin, Wyoming. Niobrara Chalk, Shale, Limestone, or Member of Mancos/Colorado/Cody Shale remains in good usage in Colorado, Nebraska, North and South Dakota, Kansas, New Mexico, Montana, and elsewhere in Wyoming.

\section{Norton Formation (age changed)}

Lower(?) and Middle Pennsylvanian

southwestern Virginia

Miller, R. L., and Meissner, C. R., Jr., 1977, Geologic map of the Big A Mountain quadrangle, Buchanan and Russel1 Counties, Virginia: U.S. Geol. Survey Geo1. Quad. Map GQ-1350.

Council Sandstone Member adopted and assigned as lower of two members of Norton Formation; age of Council is Early(?) Pennsylvanian. Age of Norton changed from Pennsylvanian to: Early(?) and Middle Pennsylvanian.

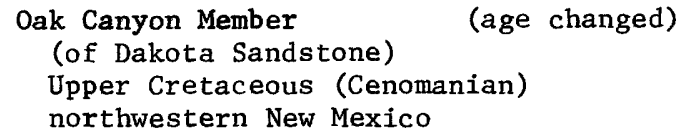

Hook, S. C., and Cobban, W. A., 1977, Pycnodonte newberryi (Stanton)-common guide fossil in Upper Cretaceous of New Mexico: New Mexico Bur. Mines and Mineral Resources Annual Report, v. 1976-1977, p. 48-54.

Age changed from Early and Late Cretaceous to: Late Cretaceous (Cenomanian).

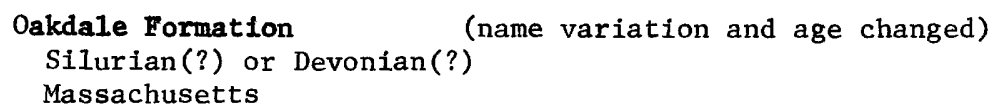

Barosh, P. J., 1976, Stratigraphy of the Webster-Worcester region, Massachusetts, in Geology of southeastern New England--Guidebook, New England Intercollegiate Geol. Conf., 68th Ann. Mtg., Boston, Mass.: Princeton, New Jersey, Science Press, p. 352-365. 
In Webster-Worcester region only, name changed from Oakdale Quartzite to: Oakdale Formation; Dakdale Quartzite remains in good usage elsewhere in Massachusetts. Age changed from Silurian and Devonian to: Silurian(?) or Devonian(?).

Ohio Shale

Upper Devonian

(assignment of bed)

northeastern Kentucky and adjoining areas in

Ohio and West Virginia

Provo, L. J., Kepferle, R. C., and Potter, P. E., 1977, Three Lick Bed: useful stratigraphic marker in Upper Devonian shale in eastern Kentucky and adjacent areas of Ohio, West Virginia, and Tennessee: U.S. Dept.

Commerce, Nat1. Tech. Inf. Service, ERDA-MERC/CR-77-2, 56 p.

Three Lick Bed adopted and assigned to: 1) Ohio Shale in northeastern Kentucky, Ohio, and West Virginia; 2) New Albany Shale in east-central Kentucky (correlates with lover part of Camp Run Member, of local usage, of New Albany in Indiana); and 3) Chattanooga Shale in south-central Kentucky (correlates with middle unit of Gassaway Member of Chattanooga in Tennessee).

\section{1d Port Formation (name adopted) \\ Lower Devonian \\ central Pennsy1vania}

Taylor, A. R., 1977, Geology and mineral resources of the Lock Haven 7-1/2-minute quadrangle, Clinton and Lycoming Counties, Pennsylvania: Pennsylvania Topog. and Geol. Survey Atlas 124a.

01d Port Formation of Conlin and Hoskins (1962) adopted. Divided into (ascending): Shriver Chert and Ridgely Sandstone Members (both reduced in rank). Overlies Keyser Formation; underlies Onondaga Formation.

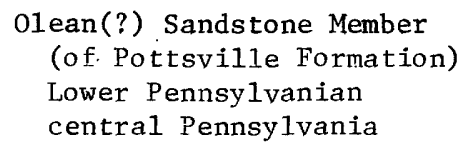

(name and age changed)

Taylor, A. R., 1977, Geology and mineral resources of the Lock Haven 7-1/2-minute quadrangle, Clinton and Lycoming Counties, Pennsylvania: Pennsylvania Topog, and Geo1. Survey At1as 124a.

In Pennsylvania, name changed from 0lean Conglomerate Member of Pottsville to: Olean(?) Sandstone Member of Pottsville; name remains unchanged in New York. Age changed from Pennsylvanian to: Early Pennsylvanian. 


\title{
Oquirrh Group (subdivided) \\ Upper Mississippian to Lower Permian (varies locally) \\ southern East Tintic Mountains, Utah
}

Morris, H. T., Douglass, R. C., and Kopf, R. W., 1977, Stratigraphy and microfaunas of the Oquirrh Group in the southern East Tintic Mountains, Utah: U.S. Geol. Survey Prof. Paper 1025, 22 p.

In southern East Tintic Mountains, central Utah, Oquirrh Group, divided into (ascending): West Canyon Limestone, Butterfield Peaks Formation, Bingham Mine Formation, and Furner Valley Limestone (new name). Overlies Paleozoic sedimentary rocks; underlies Diamond Creek Sandstone. Oquirrh remains of formation or group rank elsewhere in Utah and in southeastern Idaho. Age is Early Pennsylvanian to Early Permian only in this area; age remains Late Mississippian to Early Permian elsewhere.

Overton Conglomerate Member

(of Baseline Sandstone)

Cretaceous

southeastern Nevada

Bohannon, R. G., 1976, The tectonic and sedimentologic environment of lithium occurrences in the Muddy Mountains, Clark County, Nevada, in Vine, J. D., ed., Lithium resources and requirements by the year 2000: U.S. Geol. Survey Prof. Paper 1005, p 109-116.

Reduced in rank from Overton Fanglomerate to: Overton Conglomerate Member and assigned as one of two members to Baseline Sandstone. Age changed from Tertiary to: Cretaceous.

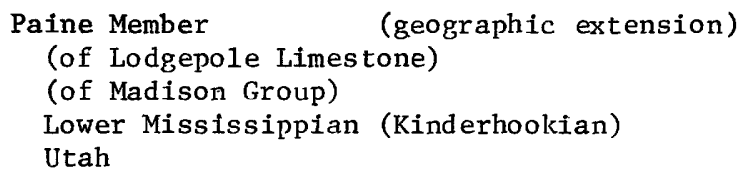

Sando, W. J., 1977, Significance of coiled Protocoralla in some Mississippiar horn corals: Palaeontology, v. 20, Pt. 1, p. 47-58.

Geographically extended from Montana, Wyoming, and Idaho into: Utah.

\author{
Pancho Rico Formation (age changed) \\ upper Miocene \\ western California
}

Addicott, W. 0., Revision of the age of the Pancho Rico Formation, central Coast Ranges, California: this report.

Age changed from early Pliocene to: late Miocene. 


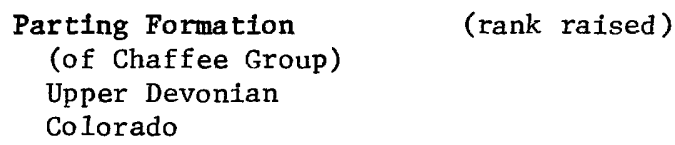

Tweto, Ogden, and Lovering, T. S., 1977, Geology of the Minturn 15-minute quadrangle, Eagle and Summit Counties, Colorado: U.S. Geol. Survey Prof. Paper 956, $96 \mathrm{p}$.

Raised in rank from Parting Quartzite Member or Parting Member to: Parting Formation and reassigned as lower formation of Chaffee Group (now raised in rank).

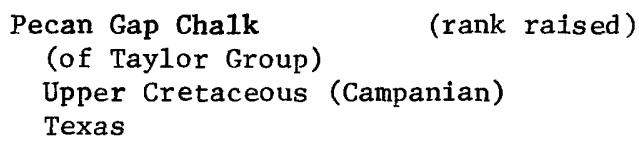

Haze1, J. E., Bybe11, L. M., Christopher, R. A., Frederiksen, N. O., May, F. E., Mclean, D. M., Poore, R. Z., Smith, C. C., Sohl, N. F., Valentine, P. C., and Witmer, R. J., 1977, Biostratigraphy of the deep corehole (Clubhouse Crossroads corehole 1.) near Charleston, South Carolina, in Rankin, D. W. ed., Studies related to the Charleston, South Carolina, earthquake of 1886-a preliminary report: U.S. Geo1. Survey Prof. Paper 1028-F, p. 71-39.

Raised in rank from Pecan Crap Chalk Member of Taylor Marl to: Pecan Gap Chalk of Taylor Group (also raised in rank). Overlies Wolfe City Sand (raised in rank) of Taylor Group; underlies Bergstrom Formation.

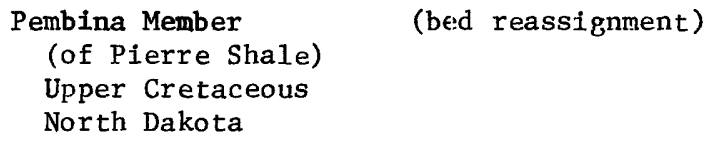

Rice, D. D., 1977, Stratigraphic sections from well logs and outcrops of. Cretaceous and Paleocene rocks, northern Great Plains, North Dakota and South Dakota: U.S. Geol. Survey Oil and Gas Inv. Chart OC-72, 3 sheets.

Ardmore Bentonite Bed geographically extended into North Dakota and reassigned in that location only to Pembina Member of Pierre Shale.

\author{
Pend Oreille Andesite (name abandoned) \\ Eocene \\ northeastern Washington
}

Pearson, R. C., and Obradovich, J. D., 1977, Eocene rocks in northeast Washington-radiometric ages and correlation: U.S. Geo1. Survey Bull. 1433, $41 \mathrm{p}$. 
Pend Oreille Andesite abandoned; its rocks now included in Sanpoil Volcanics.

\author{
Peñon Blanco Volcanics (age changed) \\ Triassic or Jurassic \\ central California
}

Morgan, B. A., III, 1976, Geologic map of the Chinese Camp and Moccasin quadrangles, Sierra Nevada, California: U.S. Geol. Misc. Field Studies Map MF-840.

Age changed from Late Jurassic to: Triassic or Jurassic.

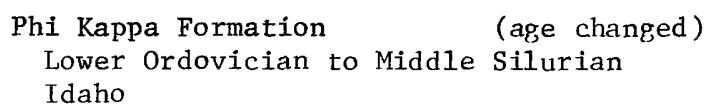

Carter, Claire, and Churkin, Michael, Jr., 1977, Ordovician and Silurian graptolite succession in the Trail Creek area, central Idaho-a graptolite zone reference section: U.S. Geol. Survey Prof. Paper $1020,37 \mathrm{p}$.

Age changed from Ordovician to: Early Ordovician to Middle Silurian.

\author{
Phosphoria Formation (geographic extension) \\ Permian \\ northwestern Utah and northeastern Nevada
}

Maughan, E. K., 1977, Petroleum source beds and trace elements in the Phosphoria Formation of Utah and Nevada, in Geological Survey research 1977: U.S. Geo1. Survey Prof. Paper 1050, p. 21.

Geographically extended into northwestern Utah and northeastern Nevada. Phosphoria Formation remains good usage in Idaho, Montana, Wyoming, and northeastern and central Utah.

\title{
Pillarian Stage (new name) \\ lower Miocene \\ Washington and oregon
}

Addicott, W. O., 1976, Neogene molluscan stages of Oregon and Washington, in Fritsche, A. E., and others, eds., The Neogene Symposium, Pacific Coast of North America, Soc. Econ. Paleontologists and Mineralogists, Pacific Sec., San Francisco, California, April 1976: p. 95-115.

Pillarian Stage adopted. Overlies Juanian Stage and underlies Newportiar Stage (both new names). 


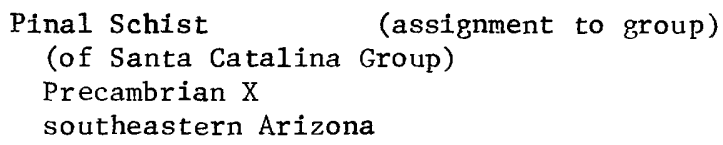

Drewes, Harald, 1977, Geologic map and sections of the Rincon Valley quadrangle, Pima County, Arizona: U.S. Geol. Survey Misc. Inv. Map I-997.

Assigned as lowermost of three formations of Santa Catalina Group; underlies Continental Granodiorite of Santa Catalina.

\author{
Pitahaya Formation (new name) \\ Lower Cretaceous \\ eastern Puer to Rico
}

M'Gonigle, J. W., 1977, The Río Abajo, Pitahaya, and Daguao Formations in eastern Puerto Rico: U.S. Geol. Survey Bull. 1435-B, 10 p.

Pitahaya Formation adopted. Overlies Río Abajo Formation (new name); underlies Quaternary deposits or rocks of Mambiche sequence (informal name); probable eastern facies of Torrecilla Breccia.

Plainfield Formation Precambrian(?)

eastern Massachusetts

Barosh, P. J., 1976, Stratigraphy of the Nebster-Worcester region, Massachusetts, in Geology of southeastern New England--Guidebook, New England Intercollegiate Geol. Conf., 68 th Ann. Mtg., Boston, Mass.: Princeton, New Jersey, Science Press, p. 352-365.

Geographically extended into eastern Massachusetts from Connecticut and Rhode Island. Age changed from Cambrian(?) to: Precambrian(?).

\footnotetext{
Pocono Formation (age changed)

Upper Devonian and Lower Mississippian

central Pennsylvania
}

Taylor, A. R., 1977, Geology and mineral resources of the Lock Haven 7-1/2-minute quadrangle, Clinton and Lycoming Counties, Pennsylvania: Pennsylvania Topog. and Geol. Survey Atlas 124a.

Age changed from Early Mississippian to: Late Devonian and Early Mississippian; age of Pocono Formation or Sandstone or Group is changed accordingly elsewhere in Pennsylvania and in Maryland, Ohio, Virginia, and West Virginia. In report area, divided into (ascending): unnamed lower sandstone member interbedded with conglomerate at Cedar Run and Burgoon Sandstone Member. 
Pole Creek Dacite upper Miocene (age changed)

northeastern Nevada

Coats, R. R., Green, R. C., Cress, L. D., and Marks, L. Y., 1977, Minera1 resources of the Jarbidge Wilderness and adjacent areas, Elko County, Nevada, with a section on Interpretation of aeromagnetic data by W. E. Davis: U.S. Geo1. Survey Bull. 1439, 79 p.

Age changed from Pliocene(?) to: late Miocene.

\author{
Portland Formation (name and age changed) \\ (of Newark Group) \\ Lower Jurassic \\ Massachusetts
}

Leo, G. W., Robinson, Peter, and Hall, D. J., 1977, Bedrock geologic map of the Ludlow quadrangle, Hampden and Hampshire Counties, south-centra1 Massachusetts: U.S. Geol. Survey Geol. Quad. Map G?-1353.

Name changed from Portland Arkose to: Portland Formation. Age changed from Late Triassic to: Early Jurassic. Portland remains in good usage in Connecticut.

Pottsville Formation (member name changed)

Lower and Middle Pennsylvanian

central Pennsylvania

Taylor, A. R., 1977, Geology and mineral resources of the Lock Haven 7-1/2-minute quadrangle, Clinton and Lycoming Counties, Pennsylvania: Pennsylvania Topog. and Geol. Survey Atlas 124a.

In Pennsylvania only, 0lean(?) Sandstone Member (name changed from olean Conglomerate Member in New York) included in Pottsville Formation. Usage of Pottsville Formation or Group remains unchanged in Ohio, New York, Maryland, Virginia, and West Virginia.

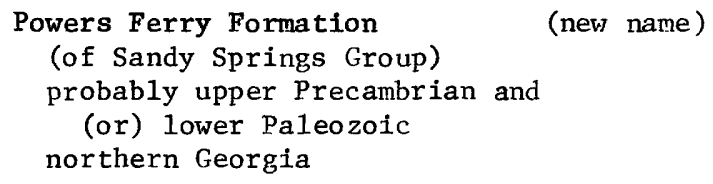

Higgins, M. H., and McConnell, K. I., The Sandy Springs Group and related rocks in the Georgia Piedmont: nomenclature and stratigraphy: this report.

Powers Ferry Formation and its Mableton Amphibolite Member adopted. Assigned to Sandy Springs Group as lowermost of four formations: underlies Chattahoochee Palisades Quartzite (new name) of Sandy Springs. 


\author{
Prisoners Harbor Member \\ (of Santa Cruz Island Volcanics) \\ upper Oligocene to middle Miocene \\ (Saucesian and Relizian) \\ Santa Cruz Island off southern California coast
}

Crowe, B. M., McLean, Hugh, Howe11, D. G., and Higgins, R. E., 1976, Petrography and major-element chemistry of the Santa Cruz Island Volcanics, in Howel1, D. G., ed., Aspects of the geologic history of the California continental borderland: Am. Assoc. Petroleum Geologists Misc. Pub. 24, p. 196-215.

Prisoners Harbor Member of Nolf and Nolf (1969) adopted as uppermost of four members of Santa Cruz Island Volcanics. Overlies Devils Peak Member of Santa Cruz Island Volcanics; underlies Monterey Formation.

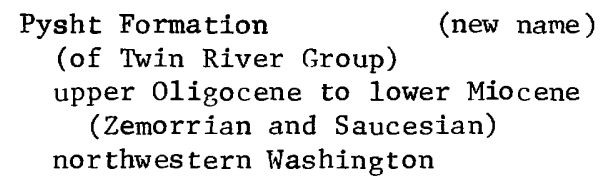

Snavely, P. D., Jr., Niem, A. R., and Pearl, J. E., Twin River Group (upper Eocene to lower Miocene)--defined to include the Hoko River, Makah, and Pysht Formations, Clallam County, Nashington: this report.

Pysht Formation adopted and assigned as upper of three new formations to Twin River Group (now raised in rank). Gradationally and, locally, unconformably overlies Makah Formation (new name) of Twin River; gradationally and conformably underlies Clallam Formation.

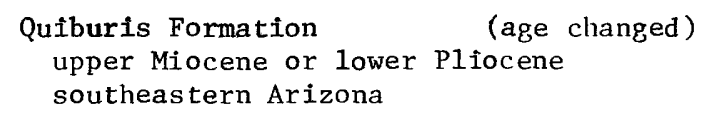

Krieger, M. H., 1977, Large landslide, composed of megabreccia, interbedded in Miocene basin deposits, southeastern Arizona: U.S. Geol. Survey Prof. Paper 1008, 25 p.

Age changed from middle Pliocene to: late Miocene or early Pliocene.

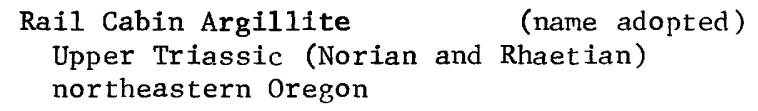

Brown, C. E., and Thayer, T. P., 1977, Geologic map of pre-Tertiary rocks. in the eastern Aldrich Mountains and adjacent areas to the south, Grant County, Oregon: U.S. Geo1. Survey Misc. Geol. Inv. Map I-1021. 
Rail Cabin Argillite of Dickinson and Vigrass (1965) adopted. Unconformably overlies Brisbois Member (also newly adopted) of Vester Formation; conformably underlies Graylock Formation (also newly adopted).

\author{
Rattlesnake Formation (age changed) \\ middle Pliocene \\ northeastern Oregon
}

Brown, C. E., and Thayer, T. P., 1977, Geologic map of pre-Tertiary rocks in the eastern Aldrich Mountains and adjacent areas to the south, Grant County, Oregon: U.S. Geol. Survey Misc. Geo1. Inv. Map I-1021.

Age changed from middle Pliocene to Pleistocene to: middle Pliocene.

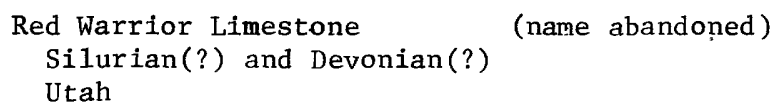

Sandberg, C. A., and Poole, F. G., 1977, Conodont biostratigraphy and depositional complexes of Upper Devonian cratonic-platform and continental shelf rocks in the Western United States, in Murphy, M. A., and others, ed Western North America: Devonian: Riverside, Calif., Univ. California, Riverside Campus Museum Contrib. no. 4, p. 144-182.

Red Warrior Limestone abandoned; it rocks now included in (ascending): Laketown Dolomite, Sevy Dolomite, Simonson Dolomite, and Guilmette Formation.

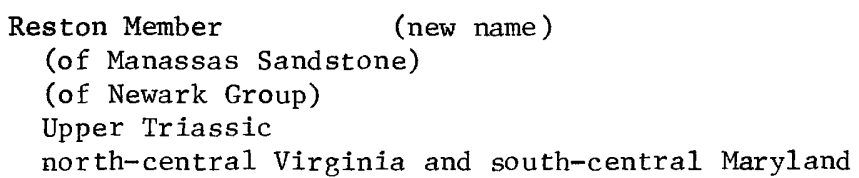

Lee, K. Y., 1977, Triassic stratigraphy in the northern part of the Culpeper basin, Virginia and Maryland: U.S. Geol. Survey Bull. 1422-C, $17 \mathrm{p}$.

Reston Member adopted and assigned as lower of two members of Manassas Sandstone of Newark Group. Underlies unnamed sandstone member of Manassas.

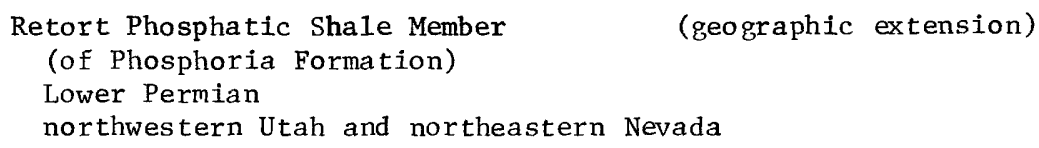

Maughan, E. K., 1977, Petroleum source beds and trace elements in the Phosphoria Formation of Utah and Nevada, in Geological Survey research 1977: U.S. Geol. Survey Prof. Paper 1050, p. 21. 
Geographically extended into northwestern Utah and northeastern Nevada. Retort Phosphatic Shale Member or Tongue remains good usage in Idaho, Montana, Wyoming, and northeastern Utah.

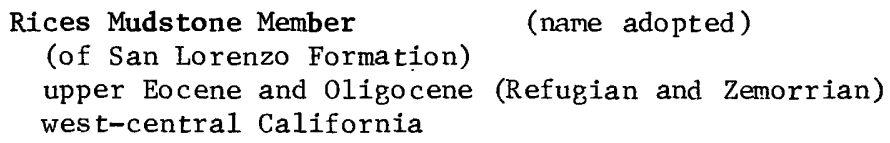

Poore, R. Z., and Brabb, E. E., 1977, Eocene and Oligocene planktonic Foraminifera from the upper Butano Sandstone and type San Lorenzo Formation, Santa Cruz Mountains, California: Jour. Foraminiferal Research, v. 7, no. 4, p. 249-272.

Rices Mudstone Member of Brabb (1960, 1964) adopted as upper of two members of San Lorenzo Formation. Paraconformably overlies Twobar Shale Member of San Lorenzo; conformably underlies Vaqueros Sandstone.

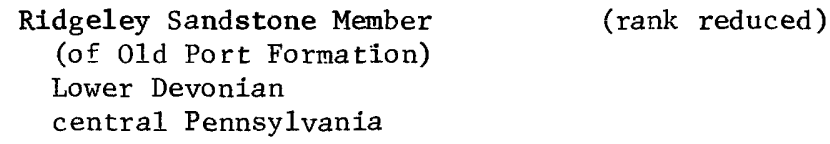

Taylor, A. R., 1977, Geology and mineral resources of the Lock Haven 7-1/2-minute quadrangle, C1inton and Lycoming Counties, Pennsylvania: Pennsylvania Topog. and Geol. Survey Atlas 124a.

In report area, Ridgeley Sandstone reduced in rank to: Ridgeley Sandstone Member and reassigned to 01d Port Formation (newly adopted) as upper of two members; overlies Shriver Chert Member (also reduced in rank in report area). Former usage of Ridgely remains unchanged elsewhere in Pennsylvania, Maryland, Virginia, and West Virginia.

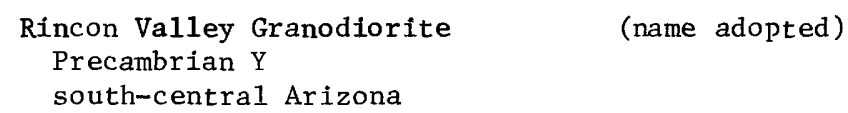




\section{Río Abajo Formation (new name) Lower(?) Cretaceous eastern Puerto Rico}

M'Gonigle, J. W., 1977, The Río Abajo, Pitahaya, and Daguao Formations in eastern Puerto Rico: U.S. Geo1. Survey Bul1. 1435-B, 10 p.

Río Abajo Formation adopted. Faulted against other stratigraphic units with its top and bottom not exposed; underlies Pitahaya Formation (new name).

\section{Robertson Formation (name adopted) \\ (of Mowich Group)' \\ Lower Jurassic (P1iensbachian and Toarcian?) \\ northeastern Oregon}

Brown, C. E., and Thayer, T. P., 1977, Geologic map of pre-Tertiary rocks in the eastern Aldrich Mountains and adjacent areas to the south, Grant County, Oregon: U.S. Geo1. Survey Misc. Geo1. Inv. Map I-1021.

Robertson Formation of Lupher (1941) adopted as lowermost of four formations of Mowich Group as used by Dickinson and Vigrass (1965). Unconformably overlies older Mesozoic rocks; conformably underlies Suplee Formation of Mowich (both a1so newly adopted).

\section{Rockcast1e Sandstone Tongue (name and age changed)}

(of Lee Formation)

Lower and Middle Pennsylvanian (Morrowan)

Kentucky

Rice, C. L., Ages of the Lee, Breathitt, Caseyville, Tradewater, and Sturgis Formations in Kentucky: this report.

Name changed from Rockcastle Sandstone or Conglomerate Member to: Rockcastle Sandstone Tongue (intertonguing with Breathitt Formation) in Pottsville escarpment area of eastern Kentucky only; former usage as Member remains unchanged elsewhere in Kentucky. Rockcastle Sandstone (formation rank) remains good usage in Tennessee and Georgia. Age changed from Early Pennsylvanian (Morrowan) to: Early and Middle Pennsylvanian (early and late Morrowan). 
Rockdale Formation

(of Wilcox Group)

(name adopted)

upper Paleocene

northeastern and central Texas

Hazel, J. E., Bybe11, L. M., Christopher, R. A., Frederiksen, N. O., May, F. E., Mclean, D. M., Poore, R. Z., Smith, C. C., Sohl, N. F., Valentine, P. C., and Witmer, R. J., 1977, Biostratigraphy of the deep corehole (C1ubhouse Crossroads corehole 1) near Charleston, South Carolina, in Rankin, D. W. ed., Studies related to the Charleston, South Carolina, earthquake of 1886--a preliminary report: U.S. Geol. Survey Prof. Paper 1028-F, p. 71-89.

Rockdale Formation of Plummer (1933) adopted and assigned as middle of three formations to Wilcox Group in northeastern and central Texas. Overlies Seguin Formation of Wilcox; underlies Sabinetown Formation of Wilcox.

Rockwood Formation

Lower and Middle Silurian

southeastern Tennessee

Milici, R. C., and Wedow, Helmuth, Jr., 1977, Upper Ordovician and Silurian stratigraphy in Sequatchie Valley and parts of the adjacent Valley and Ridge, Tennessee: U.S. Geo1. Survey Prof. Paper 996, 38 p.

In southeastern Tennessee only, Skillern Chert'Member (new name) adopted and assigned to lower part of the Rockwood Formation. Former usage of Rockwood remains unchanged elsewhere in Tennessee sind in North Carolina, Virginia, and Kentucky.

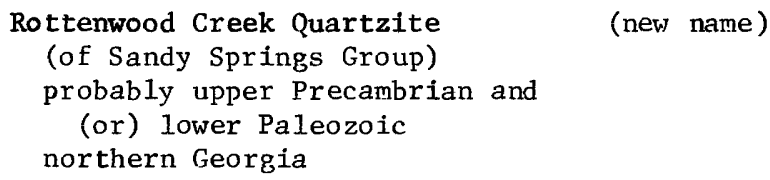

Higgins, M. H., and McConnel1, K. I., The Sandy Springs Group and related rocks in the Georgia Piedmont: nomenclature and stratigraphy: this report.

Rottenwood Creek Quartzite adopted and assigned as uppermost of four formations to Sandy Springs Group. Overlies Factory Shoals Formation (new name) of Sandy Springs. 


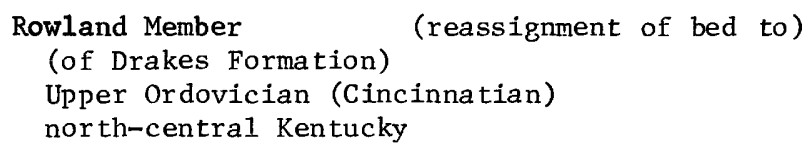

Swadley, W. C., and Gibbons, A. B., 1976, Geologic map of the Cambellsburg quadrangle, north-central Kentucky: U.S. Geol. Survey Geo1. Quad. Map G0-1364.

Marble Hil1 Marble of Owen (1859) adopted as Marble Hill Bed of Di11sboro Formation in southeastern Indiana as used by Shaver and others (1970). Geographically extended into north-central Kentucky and reassigned to Rowland Member of Drakes Formation. Rowland usage remains unchanged elsewhere in Kentucky.

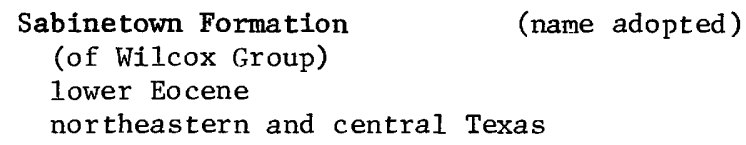

Haze1, J. E., Bybe11, L. M., Christopher, R. A., Frederiksen, N. 0., May, F. E., McLean, D. M., Poore, R. Z., Smith, C. C., Soh1, N. F., Valentine, P. C., and Witmer, R. J., 1977, Biostratigraphy of the deep corehole (C1ubhouse Crossroads corehole 1) near Charleston, South Carolina, in Rankin, D. ed., Studies related to the Charleston, South Carolina, earthquake of 1886-a preliminary report: U.S. Geol. Survey Prof. Paper 1028-F, p. 71-89.

Sabinetown Formation of Plummer (1933) adopted and assigned as uppermost of three formations to Wilcox Group in northeastern and central Texas. Overlies Rockdale Formation of Wilcox; underlies Carrizo Sand of Claiborne Group.

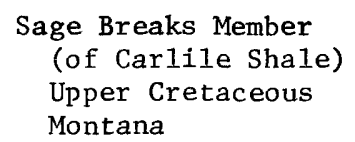

Merewether, E. A., Cobban, W. A., and Ryder, R. T., 1975, Lower Upper Cretaceous strata, Bighorn Basin, Wyoming and Montana, in Wyoming Geol. Assoc. Guidebook, 27 th Ann. Field Conf., Bighorn Basin, 1975: p. 73-84.

Geographically extended from Wyoming into: Montana. 
Sage Breaks Member

(of Cody Shale)

Upper Cretaceous

western part of Powder River basin, Wyoming

Merewether, E. A., Cobban, W. A., Matson, R. M., and Magathan, W. J., 1977, Stratigraphic diagrams with electric logs of Upper Cretaceous rocks, Powder River basin, Natrona, Campbe11, and Weston Counties, Wyoming. Section B-B': U.S. Geol. Survey Oil and Gas Inv. Chart OC-74.

Sage Breaks and overlying Niobrara Members reassigned to base of Cody Shale in western part of Powder River basin, Wyoming. Sage Breaks Member of Carlile Shale still in" good usage in eastern part of Powder River basin, Montana and Wyoming.

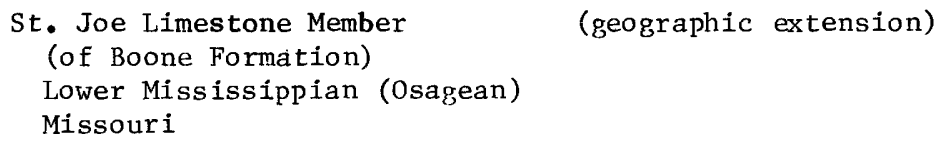

Sando, W. J., 1977, Significance of coiled Protocora1la in some Mississippian horn corals: Palaeontology, v. 20, Pt. 1, p. 47-58.

Geographica11y extended from Arkansas, Oklahoma, and Kansas into: Missouri.

\author{
St. Marks Formation (name adopted) \\ upper Miocene \\ northwestern Florida (panhandle)
}

Cameron, C. C., and Mory, P. C., 1977, Mineral resources of the Bradwell Bay Wilderness and the Sopchoppy River study area, Wakulla County, Florida: U.S. Geo1. Survey Bul1. 1431, $37 \mathrm{p}$.

St. Marks facies of Puri (1953) adopted as St. Marks Formation as used by Puri and Vernon (1964). Overlies Suwannee Limestone; underlies Hawthorn Formation.

Salmon Hornblende Schist (age changed)

Devonian

California

Irwin, W. P., 1977, Review of Paleozoic rocks of the Klamath Mountains, in Stewart, J. H., Stevens, C. H., and Fritsche, A. E., eds., Paleozoic paleogeography of the western United States, Pacific Coast Paleogeography Symposium 1: Soc. Econ. Paleontologists and Mineralogists, Pacific Sec., p. 441-454.

Age changed from Devonian or older Paleozoic to: Devonian. 


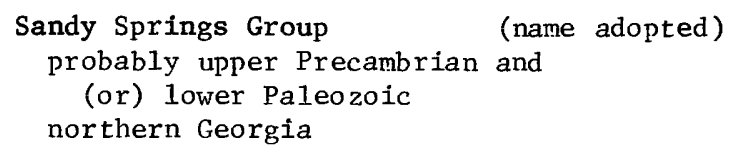

Higgins, M. H., and McConne11, K. I., The Sandy Springs Group and related rocks in the Georgia Piedmont: nomenclature and stratigraphy: this report.

"Sandy Springs Sequence" of Higgins (1966, 1968) adopted as Sandy Springs Group. Divided into (ascending): Powers Ferry Formation (with its Mableton Amphibolite Member), Chattahoochee Palisades Quartzite, Factory Shoals Formation, and Rottenwood Creek Quartzite (all new names). Fault-bounded by Long Island Creek Gneiss (new name) and Yellow Dirt Gneiss.

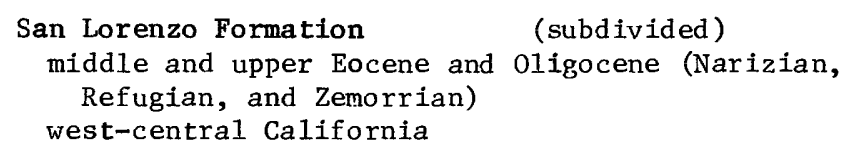

Poore, R. Z., and Brabb, E. E., 1977, Eocene and 01igocene planktonic Foraminifera from the upper Butano Sandstone and type San Lorenzo Formation, Santa Cruz Mountains, California: Jour. Foraminiferal Research, v. 7, no. 4, p. 249-272.

Divided into (ascending): Twobar Shale (middle and upper Eocene, Narizian) and Rices Mudstone (upper Eocene, Refugian, and Oligocene, Zemorrian) Members. Conformably overlies Butano Sandstone; conformab1y underlies Vaqueros Sandstone.

\title{
San Manuel Formation (age changed) upper Oligocene and lower Miocene southeastern Arizona
}

Banks, N. G., and Krieger, M. H., 1977, Geologic map of the Hayden quadrangle, Pinal and Gila Counties, Arizona: U.S. Geol. Survey Geol. Quad. Map G?-1391.

Age changed from early Miocene to: Late Oligocene and early Miocene.

\author{
Sanpoil Volcanics (geographic extension) \\ middle Eocene \\ nor theastern Washington
}

Pearson, R. C., and Obradovich, J. D., 1977, Eocene rocks in northeast Washington--radiometric ages and correlation: U.S. Geol. Survey Bull. 1433, $41 \mathrm{p}$.

Geographically extended into areas of northeasteru washington where Gerome Volcanics and Pend Oreille Andesite (both now abandoned and replaced by Sanpoil) were previously used. 
Santa Catalina Group

Precambrian $\mathrm{X}$ and $\mathrm{Y}$

(name adopted)

south-central Arizona

Drewes, Harald, 1977, Geologic map and sections of the Rincon Valley quadrangle, Pima County, Arizona: U.S. Geol. Survey Misc. Inv. Map I-997.

Santa Catalina Gneiss of B1ake (1908) adopted as Santa Catalina Group. Divided into (ascending): Pinal Schist (X), Continental Granodiorite (Y), and Wrong Mountain Quartz Monzonite (Y) (new name).

\author{
Santa Cruz Island Volcanics (name adopted) \\ upper 0ligocene to middle Miocene \\ (Saucesian and Relizian) \\ Santa Cruz Island off southern California coast
}

Crowe, B. M., McLean, Hugh, Howe11, D. F., and Higgins, R. E., 1976, Petrography and major-element chemistry of the Santa Cruz Island Volcanics, in Howe11, D. G., ed,, Aspects of the geologic history of the California continental borderland: Am. Assoc. Petroleum Geologists Misc. Pub. 24, p. 196-215.

Santa Cruz Island Volcanics of Nolf and Nolf (1969) adopted. Divided into (ascending): Griffith Canyon Member, Stanton Ranch Member, Devils Peak Member, and Prisoners Harbor Member (late 0ligocene to middle Miocene age applies to all members). Overlies in subsurface San Onofre Breccia; underlies Monterey Formation.

Santa Fe Group (member added to its formation)

Miocene to P1eistocene (varies locally)

New Mexico

Man1ey, Kim, 1977, Geologic map of the northeastern part of the Española basin, New Mexico, showing the Cejita Member (new name) of the Tesuque Formation: U.S. Geol. Survey Misc. Field Studies Map MF-877.

In New Mexico, Cejita Member adopted as upper part of its Tesuque Formation. Cejita overlies unnamed eolian sand of Tesuque and underlies unnamed P1iocene(?) gravel.

\title{
Sappington Member (age changed) \\ (of Three Forks Formation) \\ Upper Devonian and Mississippian(?) \\ Montana
}

Sandberg, C. A., and Poole, F. G., 1977, Conodont biostratigraphy and depositional complexes of Upper Devonian cratonic-platform and continental shelf rocks in the Western United States, in Murphy, M. A., and others, eds. Western North America: Devonian: Riverside, Calif., Univ. California, Riverside Campus Museum Contrib. no. 4, p. 144-182. 
Age changed from Late Devonian and Early Mississippian to: Late Devonian and Mississippian(?).

\author{
Sarten Sandstone (age changed) \\ Lower Cretaceous (A1bian) and \\ Upper Cretaceous(?) (lower Cenomanian?) \\ New Mexico
}

Landis, E. R., and Cobban, W. A., 1977, Age of top of Sarten Sandstone and base of Colorado Formation, Luna County, New Mexico, in Geological Survey research 1977: U.S. Geo1. Survey Prof. Paper 1050, p. 201.

Age changed from Early Cretaceous (Comanchean) to: Early Cretaceous (Albian) and Late Cretaceous(?) (Cenomanian?).

\title{
Sausbee Formation (new name) \\ Lower Pennsylvanian (lower Morrowan) \\ nor theastern 0k1ahoma
}

Sutherland, P. K., and Henry, T. W., 1977, Carbonate platform facies and new stratigraphic nomenclature of the Morrowan Series (Lower and Middle Pennsylvanian), northeastern Oklahoma: Geol. Soc. America Bull., v. 88, no. 3, p. 425-440.

Sausbee Formation adopted as lower of two formations in Morrowan Provincial Series. Divided into (ascending): Braggs Member and Brewer Bend Limestone Member (both new names). Unconformably overlies Pitkin Limestone; unconformably underlies McCul1y Formation (new name).

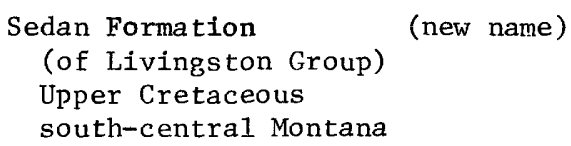

Skipp, Betty, and McGrew, L. W., 1977, The Maudlow and Sedan Formations of the Upper Cretaceous Livingston Group on the west edge of the Crazy Mountains basin, Montana: U.S. Geol. Survey Bull. 1422-B, 68 p.

Sedan Formation adopted and assigned to Livingston Group as its lower of two formations in the Sedan-Ringling area, Montana. Divided into (ascending): unnamed lower sandstone member, unnamed welded tuff member, unnamed middle sandstone member, unnamed mudstone member, Bearpaw Shale Member (reduced in rank), and Lennep Sandstone Member (reduced in rank). Overlies Eagle Sandstone; underlies Billman Creek Formation of Livingston Group. 


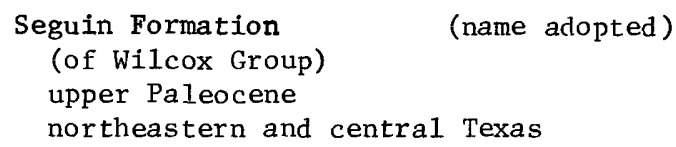

Haze1, J. E., Bybe11, L. M., Christopher, R. A., Frederiksen, N. 0., May, F. E., Mclean, D. M., Poore, R. Z., Smith, C. C., Soh1, N. F., Valentine, P. C., and Witmer, R. J., 1977, Biostratigraphy of the deep corehole (C1ubhouse Crossroads corehole 1) near Charleston, South Carolina, in Rankin, D. ed., Studies related to the Charleston, South Carolina, earthquake of 1886a preliminary report: U.S. Geo1. Survey Prof. Paper 1028-F, p. 71-89.

Seguin Formation of P1ummer (1933) adopted and assigned as lowermost of three formations to Wilcox Group in northeastern and central Texas. Overlies Wills Point Formation of Midway Group; underlies Rockdale Formation of Wilcox.

\section{Seldovian Stage (age changed) \\ lower and middle Miocene south-central Alaska}

Wolfe, J. A., 1977, Paleogene floras from the Gulf of Alaska region: U.S. Geo1. Survey Prof. Paper 997, 108 p.

Age changed from late 0ligocene(?) to middle Miocene to: early and middle Miocene.

\section{Sequatchie Formation (geographic restriction) \\ Upper Ordovician \\ southeastern Tennessee}

Milici, R. C., and Wedow, Helmuth, Jr., 1977, Upper Ordovician and Silurian stratigraphy in Sequatchie Valley and parts of the adjacent Valley and Ridg Tennessee: U.S. Geo1. Survey Prof. Paper 996, 38 p.

In southeastern Tennessee, Sequatchie Formation geographically restricted to northern Sequatchie Valley area (Shellmound Formation (new name) geographically restricted to southern Sequatchie Valley area). Former usage of Sequatchie remains unchanged elsewhere in Tennessee and in Virginia, Alabama, and Georgia.

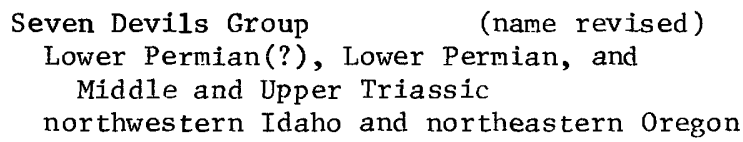

Vallier, T. L., 1977, The Permian and Triassic Seven Devils Group, western Idaho and northwestern Oregon: U.S. Geo1. Survey Bul1. 1437, 58 p. 
Raised in rank from Seven Devils Volcanics to: Seven Devils Group. Divided into (ascending): Windy Ridge (Lower Permian?), Hunsaker Creek (Lower Permian), Wild Sheep Creek (Middle and Upper Triassic), and Doyle Creek (Upper Triassic) Formations (all four new names). Geographically extended from northwestern Idaho into: northeastern Oregon. Age changed from Permian and Late Triassic to: Early Permian(?), Early Permian, and Middle and Late Triassic.

\section{Seventy Six Basalt (age changed) \\ uppermost 01igocene or lowermost Miocene northeastern Nevada}

Coats, R. R., Green, R. C., Cress, L. D., and Marks, L. Y., 1977, Minera1 resources of the Jarbidge Vilderness and adjacent areas, Elko County, Nevada, with a section on Interpretation of aeromagnetic data by W. E. Davis: U.S. Geo1. Survey Bu11. 1439, 79 p.

Age changed from 1ate Miocene(?) to: latest 01igocene or earliest Miocene.

\section{Shady Dolomite (age changed) \\ Lower and Middle Cambrian \\ Tennessee and Virginia}

Harris, L. D., and Milici, R. C., 1977, Characteristics of thin-skinned style of deformation in the southern Appalachians and potential hydrocarbon traps: U.S. Geo1. Survey Prof. Paper 1013, $40 \mathrm{p}$.

Age changed from Early Cambrian to: Early and Middle Cambrian. Shady Dolomite or Formation remains in good usage in North Carolina, Feorgia, and Alabama.

\section{Shellmound Formation (new name) \\ Upper Ordovician \\ southeastern Tennessee and northwestern Georgia}

Milici, R. C., and Wedow, Helmuth, Jr., 1977, Upper Ordovician and Silurian stratigraphy in. Sequatchie Valley and parts of the adjacent Valley and Ridge, Tennessee: U.S. Geol. Survey Prof. Paper 996, 33 p.

Shellmound Formation adopted and geographically restricted to southern Sequatchie Valley area (Sequatchie Formation geographically restricted to northern Sequatchie Valley area). Overlies Leipers Limestone; underlies Rockwood Formation. Fernvale Limestone or Formation reduced in rank to Fernvale Member and assigned to upper part of Shellmound Formation in southeastern Tennessee and northwestern Georgia; former usage of Fernvale remains unchanged elsewhere in Tennessee and in Alabama, Arkansas, Ok1ahoma, Missouri, and Illinois. 


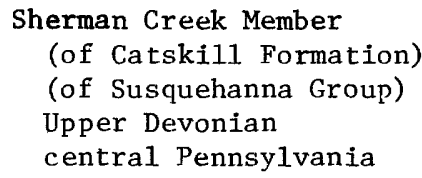

(name adopted)

Taylor, A. R., 1977, Geology and mineral resources of the Lock Haven 7-1/2-minute quadrangle, Clinton and Lycoming, Counties, Pennsylvania: Pennsylvania Topog. and reol. Survey Atlas 124a.

Sherman Creek Member of Dyson (1967) adopted as middle of three members of Catskill Formation. Overlies Irish Valley Member; underlies Duncannon Member.

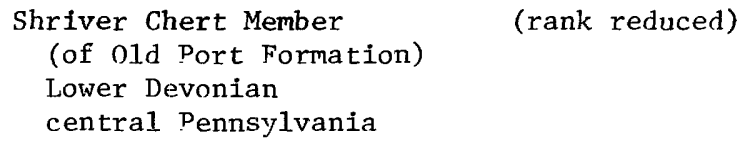

Taylor, A. R., 1977, Feology and mineral resources of the Lock Haven 7-1/2-minute quadrangle, Clinton and Lycoming Counties, Pennsylvania: Pennsylvania Topog, and reo1. Survey Atlas 124a.

In report area, Shriver Chert reduced in rank to: Shriver Chert Member and reassigned to 0ld Port Formation (newly adopted) as lower of two members; underlies Ridgeley Sandstone llember (also reduced in rank in report area). Former usage of Shriver remains unchanged elsewhere in Pennsylvania, Maryland, and West Virginia.

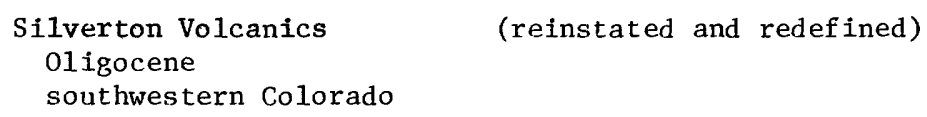

Lipman, P. W., 1976, Geologic map of the Lake City caldera area, western San Juan Mountains, southwestern Colorado: U.S. Geol. Survey Misc. Inv. Map I-962.

Reinstated and reduced in rank (stratioraphically restricted) from Silverton Volcanic Group to: Silverton Volcanics. Divided into: unnamed pyroxene andesite member, Burns Member, and Henson Member (Burns and Henson now reduced in rank).

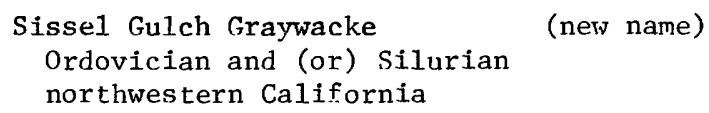

Hotz, P. E., 1977, Geology of the Yreka quadrangle, Siskiyou County, California: U.S. Geo1. Survey Bu11. 1436, 72 p. 
Sissel Gulch Graywacke adopted. Directly overlies Mallethead thrust; conformably(?) underlies Duzel Phyllite. Age is Drdovician(?).

Sisse1 Gulch Graywacke

Ordovician and (or) Silurian

northwestern California

Potter, A. W., Hotz, P. E., and Rohr, D. M., 1977, Stratigraphy and inferred tectonic framework of lower Paleozoic rocks in the eastern Klamath Mountains, northern California, in Stewart, J. H., Stevens, C. H., and Fritsche, A. E., eds., Paleozoic paleography of the western United States, Pacific Coast Paleogeography Symposium 1: Soc. Econ. Paleontologists and Mineralogists, Pacific Sec. p. 421-440.

Age changed from Ordovician(?) to: Ordovician and (or) Silurian.

\title{
Skillern Chert Member \\ (of Rockwood Formation) \\ Lower Silurian \\ southeastern Tennessee
}

Milici, R. C., and Wedow, Helmuth, Jr., 1977, Upper Ordovician and Silurian stratigraphy in Sequatchie Valley and parts of the adjacent Valley and Ridge Tennessee: U.S. Feol. Survey Prof. Paner 996, 38 p.

Skillern Chert Member adopted and assigned to lower part of Rockwood Formation in southeastern Tennessee.

\section{Slaven Chert (age changed) \\ Lower, Middle and Upper(?) Devonian \\ Nevada}

Berdan, J. M., ]977, Early Devonian ostracode assemblages from Nevada, in Murphy, M. A. and others, eds., Western North America: Devonian: Riverside, Calif., Univ. California, Riverside Campus Museum Contrib. no. 4, p. 55-64.

Age changed from Middle and Late(?) Devonian to: Early, Middle, and Late(?) Devonian.

\author{
S1ide Creek Grave1 (age changed) \\ upper Miocene \\ northeastern Nevada
}

Coats, R. R., Green, R. C., Cress, L. D., and Marks, L. Y., 1977, Minera1 resources of the Jarbidge Wilderness and adjacent areas, Elko County, Nevada, with a section on Interpretation of aeromagnetic data by W. E. Davis: U.S. Geo1. Survey Bull. 1439, 79 p. 
Age changed from Pliocene(?) to: late Miocene.

\author{
Smithville Formation \\ (assignment of member to) \\ Lower Ordovician
}

northeastern Arkansas

Wise, 0. A., Jr., Yochelson, E. L., and Clardy, B. F., 1975, Lower Ordovician stratigraphic relations at Smithville, Arkansas, and adjacent areas, in Contributions to geology of the Arkansas 0zarks, 1975: Arkansas Geol. Comm. Pub., p. 38-60.

In northeastern Arkansas only, Black Rock Formation reduced in rank to Black Rock Limestone Member and assigned to Smithville Formation. Smithville usage remains unchanged in Kansas and Missouri and elsewhere in Arkansas.

\title{
Sprinkle Formation (name adopted) upper Cretaceous (Campanian) central Texas
}

Hazel, J. E., Bybel1, L. M., Christopher, R. A., Frederiksen, N. O., May, F. E., McLean, D. M., Poore, R. Z., Smith, C. C., Sohl, N. F., Valentine, P. C., and Witmer, R. J., 1977, Biostratigraphy of the deep corehole (Clubhouse Crossroads corehole 1) near Charleston, South Carolina, in Rankin, D. ed., Studies related to the Charleston, South Carolina, earthquake of 1886-a preliminary report: U.S. Geol, Survey Prof. Paper 1028-F, p. 71-39.

Sprinkle Formation of Young (1965) adopted. Overlies Burditt Marl; underlies Wolfe City Sand of Taylor Group (both raised in rank).

\author{
Stanton Ranch Member (name adopted) \\ (of Santa Cruz Island Volcanics) \\ upper Oligocene to middle Miocene \\ (Saucesian and Relizian) \\ Santa Cruz Island off. southern California coast
}

Crowe, B. M., McLean, Hugh, Howel1, D. F., and Higgins, R. E., 1976, Petrography and major-element chemistry of the Santa Cruz Island Volcanics, in Howel1, D. G., ed., Asnects of the geologic history of the California continental borderland: Am. Assoc. Petroleum Geologists Misc. Pub. 24, p. 196-215.

Stanton Ranch Member of Nolf and Nolf (1969) adopted as one of four members of Santa Cruz Island Volcanics. Overlies Griffith Canyon Member and underlies Devils Peak Member, both of Santa Cruz Island Volcanics. 


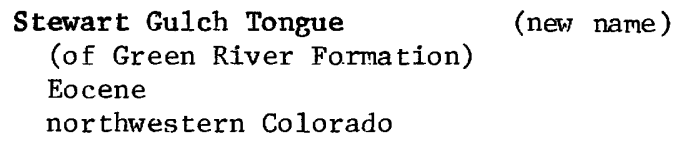

Hail, W. J., Jr., 1977, Stewart Gulch Tongue--a new tongue of the Eocene Green River Formation, Piceance Creek basin, Colorado: U.S. Geol. Survey Bull. 1422-E, 8 p.

In northwestern Colorado only, Stewart Gulch Tongue adopted and assigned as uppermost of six named units of Green River Formation. Overlies Parachute Creek Member of Green River; intertongues with Unita Formation.

\author{
Sturgis Formation (age changed) \\ Middle and Upper Pennsylvanian and \\ Lower Permian \\ western Kentucky
}

Rice, C. L., Ages of the Lee, Breathitt, Caseyville, Tradewater, and Sturgis Formations in Kentucky: this report.

Age changed from Middle and Late Pennsylvanian (Des Moinesian and Missourian) to: Middle and Late Pennsylvanian (Des Moinesian and Missourian) and Early Permian. Age of its Carthage Limestone Member (its uppermost named member) remains Late Pennsylvanian.

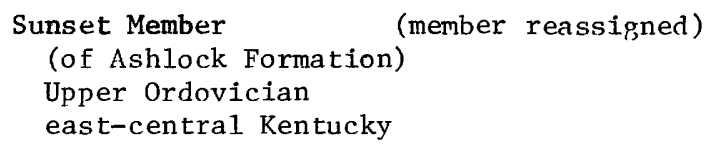

Weir, G. W., and McDowell, R. C., 1976, Geologic map of the Preston quadrangle, Bath and Montgomery Counties, Kentucky: U.S. Geol. Survey Geo1. Quad Map GQ-1334.

In report area only, reassigned to top of underlying Ashlock Formation; remains member of Bull Fork Formation elsewhere in Kentucky.

\author{
Suplee Formation (name adopted) \\ (of Mowich Group) \\ Lower Jurassic (P1iensbachian? and Toarcian) \\ northeastern Oregon
}

Brown, C. E., and Thayer, T. P., 1977, Feologic map of pre-Tertiary rocks in the eastern Aldrich Mountains and adjacent areas to the south, Grant County, Oregon: U.S. Feol. Survey Misc. Geol. Inv. Map I-1021. 
Suplee Formation of Lupher (1941) adopted as one of four formations of Mowich Group as used by Dickinson and Vigrass (1965). Conformably overlies Robertson Formation of Mowich (both newly adopted) or unconformably overlies older Mesozic rocks; conformably underlies Nicely Formation of Mowich (both newly adopted).

\section{Susquehanna Group (new formation assigned to) Upper Devonian and Lower Mississippian central Pennsylvania}

Taylor, A. R., 1977, Geology and mineral resources of the Lock Haven 7-1/2-minute quadrangle, Clinton and Lycoming Counties, Pennsylvania: Pennsylvania Topog. and Geol. Survey Atlas 124a.

Divided into (ascending): Harre11, Brallier, Lock Haven (newly adopted to replace now abandoned Chemung Formation), and Catskill Formations.

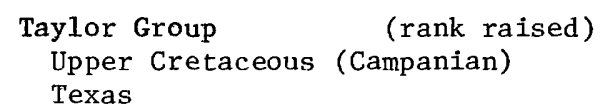

Hazel, J. E., Bybe11, L. M., Christopher, R. A., Frederiksen, N. O., May, F. E., Mclean, D. M., Poore, R. Z., Smith, C. C., Sohl, N. F., Valentine, P. C., and Witmer, R. J., 1977, Biostratigraphy of the deep corehole (C1ubhouse Crossroads corehole 1) near Charleston,, South Carolina, in Rankin, D. W. ed., Studies related to the Charleston, South Carolina, earthquake of 1886-a preliminary report: U.S. Feo1. Survey Prof. Paper 1028-F, p. 71-89.

Raised in rank to Taylor Group in some areas of Texas; Taylor Mar1 remains in good usage in Louisiana and elsewhere in Texas. Divided into (ascending): Wolfe City Sand and Pecan Fap Chalk (now both raised in rank). Overlies Sprinkle Formation; underlies Bergstrom Formation.

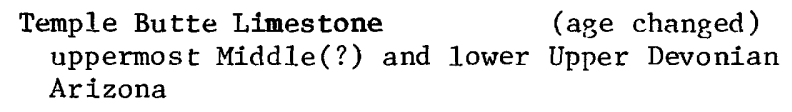

Elston, D. P., and Bressler, S. L., 1977, Paleomagnetic poles and polarity zonation from Cambrian and Devonian strata of Arizona: Earth and Planetary Sci. Ltrs., v. 36, no. 3, p. 423-433.

Age changed from late Middle or early Late Devonian to: latest Middle(?) and early Late Devonian. 


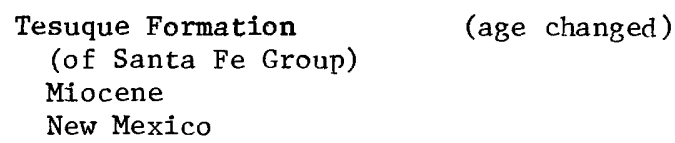

Manley, Kim, and Naeser, C. W., 1977, Fission-track ages for tephra layers in upper Cenozoic rocks, Española basin, New Mexico: Isochron/West, no. 18 p. 13-14.

Age changed from middle(?) Miocene to early Pliocene to: Miocene.

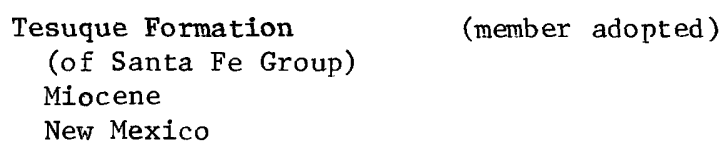

Manley, Kim, 1977, Geologic map of the northeastern part of the Española basin, New Mexico, showing the Cejita Member (new name) of the Tesuque Formation: U.S. Geol. Survey Misc. Field Studies Map MF-877.

Cejita Member adopted as upper part of Tesuque Formation of Santa Fe Group; overlies unnamed eolian sand of Tesuque and underlies unnamed Pliocene(?) gravel.

Texas Creek Granodiorite (age changed)

Upper Triassic or Lower Jurassic

southeastern Alaska

Berg, H. C., Elliott, R. L., Smith, J. G., Pittman, T. L., and Kimball, A. L., 1977, Mineral resources of the Granite Fiords Wilderness study area, Alaska: U.S. Geo1. Survey Bull. 1403, 151 p.

Age changed from Jurassic or Cretaceous to: Late Triassic or Early Jurassic.

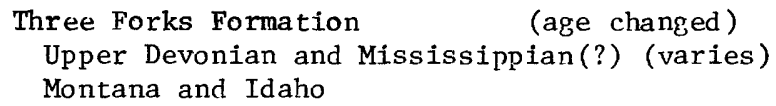

Sandberg, C. A., and Poole, F. G., 1977, Conodont biostratigraphy and depositional complexes of Upper Devonian cratonic-platform and continental shelf rocks in the Western United States, in Murphy, M. A., and others, ets Western North America: Devonian: Riverside, Calif., Univ. California, Riverside Campus Museum Contrib. no. 4, p. 14/4-182.

In Montana where Sappington Member is present, age changed from Late Devonian and Early Mississippian to: Late Devonian and Mississippian(?). Age remains Late Devonian and Early Mississippian in Idaho, Wyoming, North and South Dakota, and Utah. 


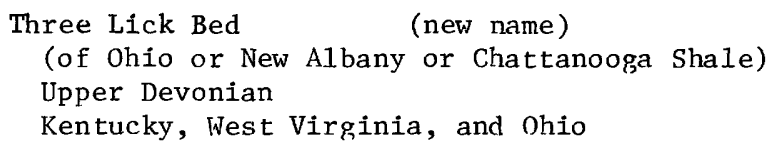

Provo, L. J., Kepferle, R. C., and Potter, P. E., 1977, Three Lick Bed: useful stratigraphic marker in Upper Devonian shale in eastern Kentucky and adjacent areas of Ohio, West Virginia, and Tennessee: U.S. Dept. Commerce, Nat1. Tech. Inf. Service, ERDA-MFRC/CR-77-2, 56 p.

Three Lick Bed adopted and assigned to: 1) Ohio Shale in northeastern Kentucky, Ohio, and West Virginia; 2) New Albany Shale in east-central Kentucky (correlates with lower part of Camp Run Member, of local usage, of New Albany in Indiana); and 3) Chattanooga Shale in south-central Kentucky (correlates with middle unit of Gassaway Member of Chattanooga in Tennessee).

\section{Tiger Formation (age changed) \\ Eocene (post-Sanpoil) and younger \\ northeastern Washington}

Pearson, R. C., and Obradovich, J. D., 1977, Eocene rocks in northeast Washington--radiometric ages and correlation: U.S. Geol. Survey Bull. 1433, $41 \mathrm{p}$.

Age changed from Tertiary to: Eocene (post-Sanpoil) and younger.

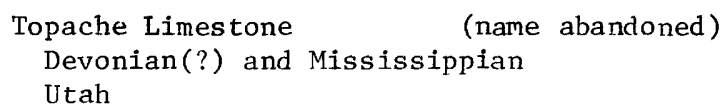

Sandberg, C. A., and Poole, F. G., 1977, Conodont biostratigraphy and depositional complexes of Upper Devonian cratonic-platform and continental shelf rocks in the Western United States, in Murphy, M. A., and others, eds., Western North America: Devonian: Riverside, Calif., Univ. California, Riverside Campus Museum Contrib. no. 4, p. 144-182.

Topache Limestone abandoned; its rocks now included in (ascending): Fitchville Formation, Gardison Limestone, Deseret Limestone, and Humbug Formation. 


\section{Tor Limestone (age changed) \\ Lower Devonian}

central Nevada

Matti, J. C., and McKee, E. H., 1977, Silurian and Lower Devonian paleogeography of the outer continental shelf of the Cordilleran miogeosyncline, central Nevada, in Stewart, J. H., Stevens, C. H., and Fritsche, A. E., eds., Paleozoic paleogeography of the western United States, Pacific Coast Paleogeography Symposium 1: Soc. Econ. Paleontologists and Mineralogists, Pacific Sec., p. 181-215.

Age changed from Devonian to: Early Devonian.

\section{Trail Creek Formation (age changed)}

Lower and Middle Silurian

Idaho

Carter, Claire, and Churkin, Michael, Jr., 1977, Ordovician and Silurian graptolite succession in the Trail Creek area, central Idaho-a graptolite zone reference section: U.S. Geol. Survey Prof. Paper $1020,37 \mathrm{p}$.

Age changed from Middle Silurian to: Early and Middle Silurian.

\section{Trent Mar1 (age changed) \\ upper 0ligocene and lower Miocene \\ North Carolina}

Hazel, J. E., Bybell, L. M., Christopher, R. A., Frederiksen, N. O., May, F. E., McLean, D. M., Poore, R. Z., Smith, C. C., Soh1, N. F., Valentine, P. C., and Witmer, R. J., 1977, Biostratigraphy of the deep corehole (Clubhouse Crossroads corehole 1) near Charleston, South Carolina, in Rankin, D. ed., Studies related to the Charleston, South Carolina, earthquake of 1386a preliminary report: U.S. Geol. Survey Prof. Paper 1028-F, p. 71-39.

Age changed from early Miocene to: late 0ligocene and early Miocene.

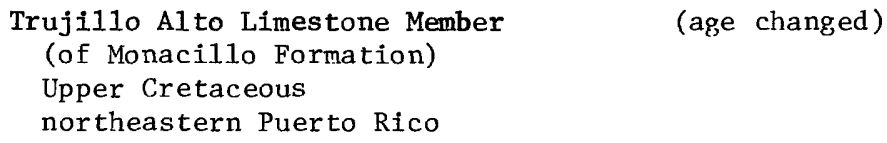

Pease, M. H., Jr., and Monroe, W. H., 1977, Geologic map of the San Juan quadrangle, Puerto Rico: U.S. Geo1. Survey Misc. Geo1. Inv. Map I-1010. Age changed from Late Cretaceous and early Tertiary(?) to: Late Cretaceous 
Tully Limestone Member

(rank reduced)

(of Mahantango Formation)

Middle Devonian

central Pennsylvania

Taylor, A. R., 1977, Geology and mineral resources of the Lock Haven 7-1/2-minute quadrangle, Clinton and Lycoming Counties, Pennsylvania: Pennsylvania Topog. and Geol. Survey Atlas 124a.

In report area, Tully Limestone reduced in rank to: Tully Limestone Member and assigned to Mahantango Formation as upper of two members; overlies unnamed shale member. Former usage of Tully remains unchanged elsewhere in Pennsylvania and New York.

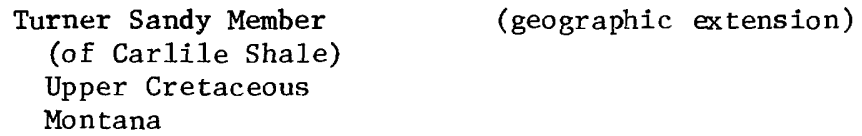

Merewether, E. A., Cobban, W. A., and Ryder, R. T., 1975, Lower Upper Cretaceous strata, Bighorn Basin, Wyoming and Montana, in Wyoming Geol. Assoc. Guidebook, 27 th Ann. Field Conf., Bighorn Basin, 1975: p. 73-84.

Geographically extended from Wyoming and South Dakota into: Montana.

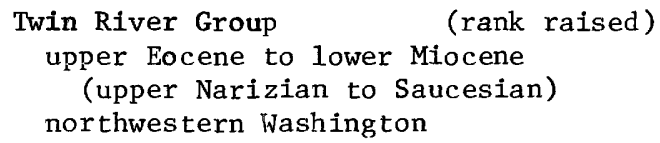

Snavely, P. D., Jr., Niem, A. R., and Pear1, J. E., Twin River Group (upper Eocene to 1ower Miocene)-defined to include the Hoko River, Makah, and Pysht Formations, Clallam County, Washington: this report.

Twin River Formation raised in rank to: Twin River Group. Divided into (ascending): Hoko River, Makah, and Pysht Formations (all new names). Conformably overlies Lyre Formation; gradationally and conformably underlies Clallam Formation.

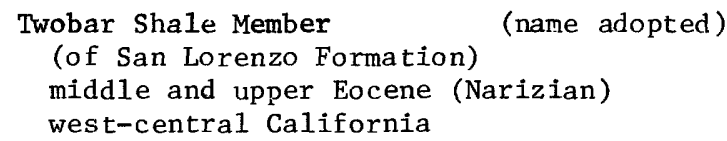

Poore, R. Z., and Brabb, E. E., 1977, Eocene and Oligocene planktonic Foraminifera from the upper Butano Sandstone and type San Lorenzo Formatior, Santa Cruz Mountains, California: Jour. Foraminiferal Research, v. 7, no. 4, p. 249-272. 
Twobar Shale Member of Brabb $(1960,1964)$ adopted as lower of two members of San Lorenzo Formation. Conformably overlies Butano Sandstone; paraconformably underlies Rices Mudstone Member of San Lorenzo.

\section{Two Medicine Formation}

Upper Cretaceous

northwestern Montana

Rice, D. D., 1976, Stratigraphic sections from well logs and outcrops of Cretaceous and Paleocene rocks, northern Great Plains, Montana: U.S. Geol. Survey Oil and Gas Inv. Chart OC-71, 3 sheets.

Ardmore Bentonite Bed reassigned to Two Medicine Formation west of Sweetgrass Arch in northwestern Montana; Ardmore reassigned to Cokedale Formation in Livingston area and Crazy Mountains Basin of southwestern Montana. Ardmore not assigned to Two Medicine elsewhere in Montana.

Uwharrie Formation (age changed)

upper Precambrian and (or) Cambrian

North Carolina

Seiders, V. M., and Wright, J. E., 1977, Geology of the Carolina volcanic slate belt in the Asheboro, North Carolina, area, in Burt, E. R., ed., Field guides for Geol. Soc. America, Southeastern Sec. Mtg., Winston-Salem, N.C.: North Carolina Dept. Nat. and Econ. Resources, p. 1-34.

Age changed from Cambrian to: late Precambrian and (or) Cambrian.

Verendrye Member

(of Pierre Shale)

(geographic extension)

Upper Cretaceous

eastern North Dakota

Rice, D. D., 1976, Correlation chart of Cretaceous and Paleocene rocks of the northern Great Plains: U.S. Geol. Survey Oil and Gas Inv. Chart OC-70.

Geographically extended from South Dakota into: eastern North Dakota.

Vester Formation (subdivided)

Upper Triassic

Oregon

Brown, C. E., and Thayer, T. P., 1977, Geologic map of pre-Tertiary rocks in the eastern Aldrich Mountains and adjacent areas to the south, Grant County, Oregon: U.S. Geol. Survey Misc. Geo1. Inv. Map I-1021. 
Divided into (ascending): Begg Member and Brisbois Member (both newly adopted). Unconformably overlies Paleozoic rocks; unconformably underlies Rail Cabin Argillite (also newly adopted).

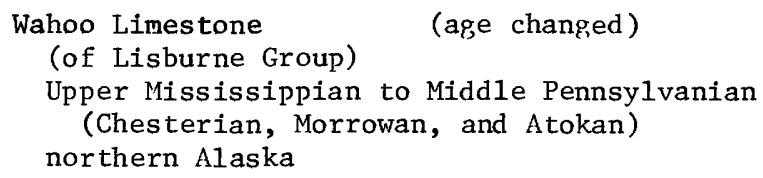

Armstrong, A. K., and Mamet, B. L., 1977, Carboniferous microfacies, microfossils, and corals, Lisburne Group, Arctic Alaska: U.S. Geol. Survey Prof. Paper 849, 144 p.

Age changed from Late Mississippian to Permian to: Late Mississippian to Middle Pennsylvanian (Chesterian, Morrowan, and Atokan).

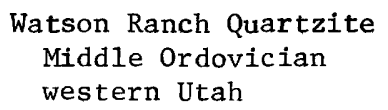

Berdan, J. M., 1976, Middle Ordovician leperditicopid ostracodes from the Ibex area, Millard County, western Utah: Brigham Young Univ. Geology Studies, v. 23, pt. 3, p. 37-65.

Age refined from Ordovician to: Middle ordovician.

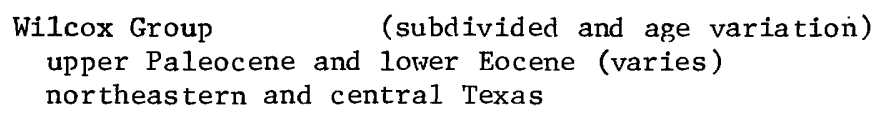

Haze1, J. E., Bybe11, L. M., Christopher, R. A., Frederiksen, N. O., May, F. E., McLean, D. M., Poore, R. Z., Smith, C. C., Soh1, N. F., Valentine, P. C., and Witmer, R。 J., 1977, Biostratigraphy of the deep corehole (Clubhouse Crossroads corehole 1) near Charleston, South Carolina, in Rankin, D. W. ed., Studies related to the Charleston, South Carolina, earthquake of 1886-a preliminary report: U.S. Geol. Survey Prof. Paper 1028-F, p. 71-89.

In northeastern and central Texas, Wilcox Group divided into (ascending): Sequin Formation (upper Paleocene), Rockdale Formation (upper Paleocene), and Sabinetown Formation (lower Eocene). Overlies Wills Point Formation of Midway Group; underlies Carrizo Sand of Claiborne Group. Remains formation or group rank in Kentucky, Tennessee, and elsewhere in Texas; remains group rank in Alabama, Mississippi, Louisiana, Georgia, Arkansas, and Illinois; remains formation rank in Missouri. Over-all age remains Paleocene and early and middle Eocene (varies locally). 


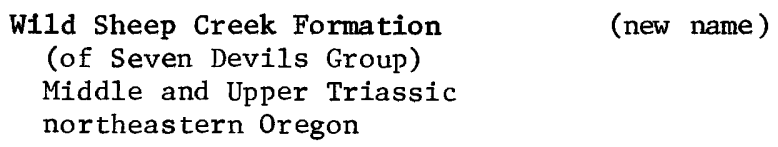

Vallier, T. L., 1977, The Permian and Triassic Seven Devils Group, western Idaho and northwestern Oregon: U.S. Geol. Survey Bul1. 1437, 58 p.

Wild Sheep Creek Formation adopted and assigned as one of four formations to Seven Devils Group (now raised in rank). Unconformably overlies Hunsaker Creek Formation and conformably underlies Doyle Creek Formation (both new names of Seven Devils).

\section{Williwaw Cove Formation (age changed) \\ lower Pleistocene (K/Ar 1.7 m.y.) \\ southwestern Alaska}

Schol1, D. W., Marlow, M. S., McLeod, N. S., and Buffington, E. C., 1976, Episodic Aleutian Ridge igneous activity: implications of Miocene and younger submarine volcanism west of Buldir Island: Geol. Soc. America Bul1., v. 87, no. 4, p. 547-554.

Age changed from Tertiary or Quaternary to: early Pleistocene (K/Ar $\left.1.7 \mathrm{~m} \cdot \mathrm{y}_{\bullet}\right)$.

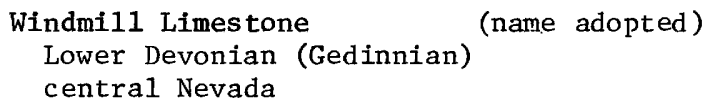

Berdan, J. M., ]977, Early Devonian ostracode assemblages from Nevada, in Murphy, M. A. and others, eds., Western North America: Devonian: Riverside, Calif., Univ. California, Riverside Campus Museum Contrib. no. 4, p. 55-64.

Windmi11 Limestone of Johnson (1965) adopted. Overlies Roberts Mountains Formation; underlies Rabbit Hill Limestone.

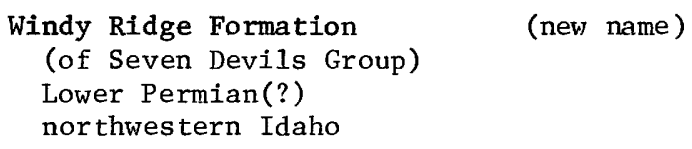

Vallier, T. L., 1977, The Permian and Triassic Seven Devils Group; western Idaho and northwestern Oregon: U.S. Geol. Survey Bull. 1437, 58 p.

Windy Ridge Formation adopted and assigned as lowermost of four formations to Seven Devils Group (now raised in rank). Base not exposed; unconformably(?) underlies Hunsaker Creek Formation (new name) of Seven Devils. 
Wise Formation

(age changed)

Middle Pennsylvanian

southwestern Virginia

Miller, R. L., and Meissner, C. R., Jr., 1977, Geologic map of the Big A Mountain quadrangle, Buchanan and Russell Counties, Virginia: U.S. Geol. Survey Geo1. Quad. Map GQ-1350.

Age changed from Pennsylvanian to: Middle Pennsylvanian.

Wishkahan Stage (new name)

upper Miocene

Washington and Oregon

Addicott, W. 0., 1976, Neogene molluscan stages of Oregon and Washington, in Fritsche, A. E., and others, eds., The Neogene Symposium, Pacific Coast of North America, Soc. Econ. Paleontologists and Mineralogists, Pacific Sec., San Francisco, California, April 1976: p. 95-115.

Wishkahan Stage adopted. Overlies Newportian Stage and underlies Graysian Stage (both new names).

\author{
Witch Member (new name) \\ (of Keating Formation) \\ (of Escabrosa Group) \\ Lower Mississippian (Tournasian) \\ southwestern New Mexico and southeastern Arizona
}

Armstrong, A. K., and Mamet, B. L., The Bugle and Witch Hembers of the Keating Formation, Escabrosa Group, and the Mississippian nomenclature in the Big Hatchet Mountains, Hidalgo County, New Mexico: this report.

Witch Member adopted as upper of two members of Keating Formation conformably overlies Bugle Member (new name of Keating); unconformably underlies Hachita Formation.

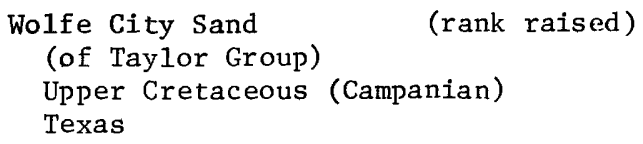

Haze1, J. E., Bybe11, L. M., Christopher, R. A., Frederiksen, N. 0., May, F. E., Mclean, D. M., Poore, R. Z., Smith, C. C., Soh1, N. F., Valentine, P. C., and Witmer, R. J., 1977, Biostratigraphy of the deep corehole (Clubhouse Crossroads corehole 1) near Charleston, South Carolina, in Rankin, D. ed., Studies related to the Charleston, South Carolina, earthquake of 1886-a preliminary report: U.S. Geo1. Survey Prof. Paper 1028-F, p. 71-89. 
Raised in rank from Wolfe City Sand Member of Taylor Marl to: Wolfe City Sand of Taylor Group (also raised in rank). Overlies Sprinkle Formation; underlies Pecan Gap Chalk (raised in rank) of Taylor Group.

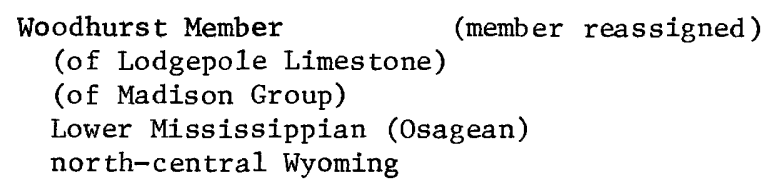

Sando, W. J., 1975, Stratigraphic sections of the Madison Limestone and Amsden Formation, west flank of the Bighorn basin, Wyoming, in Wyoming Geo1. Assoc. Guidebook, 27th Ann. Field Conf., Bighorn Basin, 1975: p. 129-137.

In north-central Wyoming only, Woodhurst reassigned as member of Madison Limestone; Woodhurst remains member of Lodgepole Limestone of Madison Group in Montana and Idaho and elsewhere in Wyoming.

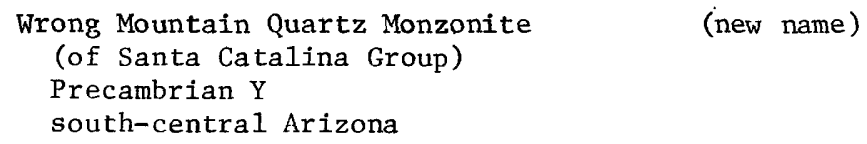

Drewes, Harald, 1977, Geologic map and sections of the Rincon Valley quadrangle, Pima County, Arizona: U.S. Geol. Survey Misc. Inv. Map I-997.

Wrong Mountain Quartz Monzonite adopted as uppermost of three formations of Santa Catalina Group; overlies Continental Granodiorite of Santa Catalina.

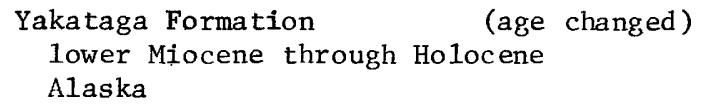

P1afker, George, and Addicott, W. 0., 1976, Glaciomarine deposits of Miocence through Holocene age in the Yakatage Formation along the Gulf of Alaska margin, Alaska, in Miller, T. P., ed., Recent and ancient sedimentary environments in Alaska: Anchorage, Alaska Geol. Soc. Symposium Proc., p. Q1-Q23.

Age changed from middle Miocene to early Pleistocene to: early Miocene through Holocene. 


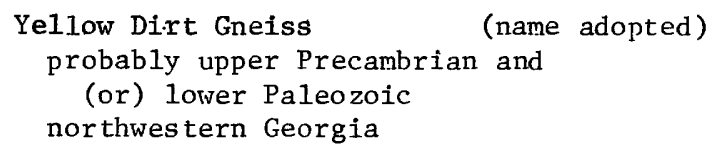

Higgins, M. H., and McConnel1, K. I., The Sandy Springs Group and related rocks in the Georgia Piedmont: nomenclature and stratigraphy: this report.

Yellow Dirt Gneiss of Crawford and Medlin (1974) adopted. Bounds Sandy Springs Group and is everywhere fault-bounded. 


\title{
REVISION OF THE AGE OF THE PANCHO RICO FORMATION, CENTRAL COAST RANGES, CALIFORNIA
}

\author{
By Warren 0 . Addicott 1
}

The Pancho Rico. Formation is a relatively thin--as much as $380 \mathrm{~m}$ thick (Durham, 1973)--marine sandstone and sandy mudstone unit of late Tertiary age in the Salinas basin of the central California Coast Ranges. This neritic unit represents the final regressive stage of the Miocene depositional cycle of the California Coast Ranges west of the San Andreas fault and the termination of marine conditions in the Salinas basin. This report summarizes paleontological data from the formation and revises the age from early Pliocene to late Miocene to agree with recent recalibration of the Pacific coast marine chronologies.

Outcrops of the Pancho Rico extend from the San Andreas fault westward to the foothills of the Santa Lucia Range, a distance of about $45 \mathrm{~km}$. The formation extends $80 \mathrm{~km}$ from San Benito southward to near San Miguel. Exposures along the east side of the basin define a broad, continuous outcrop pattern of gentle westward-dipping strata, but along the west side exposures are confined to narrow belts and are discontinuous.

\section{STRAT IGRAPHY}

The Pancho Rico Formation was named by Reed (1925, p. 606 [as Poncho Rico]) for marine strata exposed along the east side of the Salinas Valley. Later, Durham and Addicott (1964) formally defined the unit to include those marine strata that generally overlie the Monterey Formation and underlie the nonmarine Paso Robles Formation.

The Pancho Rico consists mostly of sandstone, but mudstone (sandy, diatomaceous, and siliceous) and minor conglomerate are also present. The formation unconformably overlies granitic basement of Late Cretaceous age in most of the northern part of the basin--the Gabilan High of Durham (1973). Farther south, it overlies the Monterey Formation and, by inference, the Santa Margarita Formation in the southernmost part of its distributional area. The contact with the

1/U.S. Geological Survey, Menlo Park, Calif. 
underlying mudstone and shale of the Monterey Formation is usually conformable. The Pancho Rico is conformably overlain by conglomerate and sandstone of the Pliocene and Pleistocene Paso Robles Formation in the northern part of its outcrop area. Farther south, the Paso Robles unconformably overlies the Pancho Rico (Durham, 1973); along the north margin of the La Panza Range, conglomerate of the Paso Robles Formation directly overlies the Santa Margarita Formation, which is the sandy, basin-margin facies equivalent of the siliceous shale (Hames Member) and diatomite (Buttle Member) of the Monterey Formation (Durham, 1973).

FOSSILS AND AGE

The invertebrate macrofauna of the Pancho Rico includes about 140 known taxa (Durham and Addicott, 1965) of which pectinids, muricid gastropods, sand dollar echinoids, and a giant barnacle are the most conspicuous elements. These correspond closely to the fauna of the Jacalitos Formation of former usage (lower part of the Etchegoin Formation) of the Coalinga area of the San Joaquin basin to the east. Accordingly, the Pancho Rico has been referred to the "Jacalitos" Stage and, until recent1y, has been considered early Pliocene (Nomland, 1917; Woodring and Bramlette, 1950; Durham and Addicott, 1965). Recalibration of the California provincial benthic chronologies (Berggren, 1969, 1972; Addicott, 1972, fig. 3), however, has shown that this part of the late Tertiary is of latest Miocene age in terms of the European standard. Foraminiferal as semblages from the Pancho Rico contain a few shallowwater benthic species that are not age diagnostic. The only published report of diatom and silicoflagellate assemblage from the Pancho Rico--a locality about $16 \mathrm{~km}$ northeast of King City--listed species that are similar to those in assemblages from the lower part of the Sisquoc Formation of the Santa Maria basin (Wornardt, 1967). 
THE BUGLE AND WITCH MEMBERS OF THE KEATING FORMATION, ESCABROSA GROUP, AND THE MISSISSIPPIAN NOMENCLATURE IN THE BIG HATCHET MOUNTAINS, HIDALGO COUNTY, NEW MEXICO

By Augustus K. Armstrong ${ }^{1}$ and Bernard L. Mamet ${ }^{2}$

The Escabrosa Limestone, of Mississippian age, was named by G. H. Girty (in Ransome, 1904) for the lower Carboniferous section on Escabrosa Ridge, west of Bisbee, Cochise County, southeastern Arizona (fig. 1). The Escabrosa Limestone in the Chiricahua and Pedregosa Mountains of southeastern Arizona and southwestern New Mexico was elevated by Armstrong $(1962,1970)$ to the Escabrosa Group and divided into two newly named formations: the Keating Formation containing two informal members, $A$ and $B$; and the overlying Hachita Formation (fig. 2).

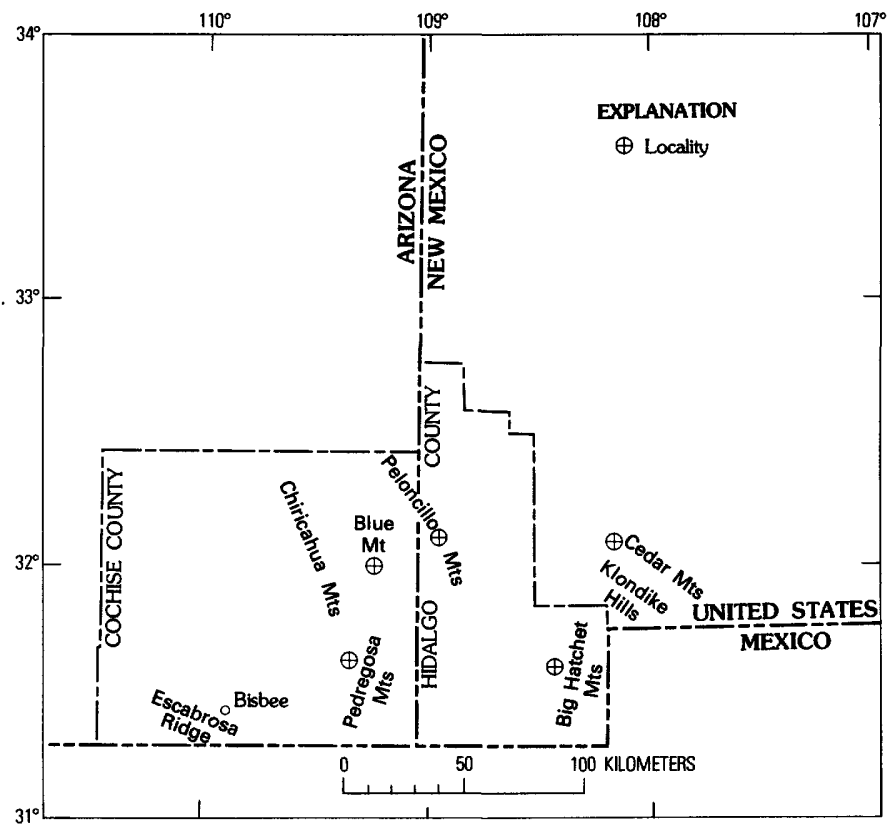

Figure 1.-Localities in southeastem Arizona and southwestem New Mexico.

$\underline{1} /$ U.S. Geological Survey, Menlo Park, Calif.

$\underline{2}$ /University of Montreal, Montreal, Quebec, Canada. 


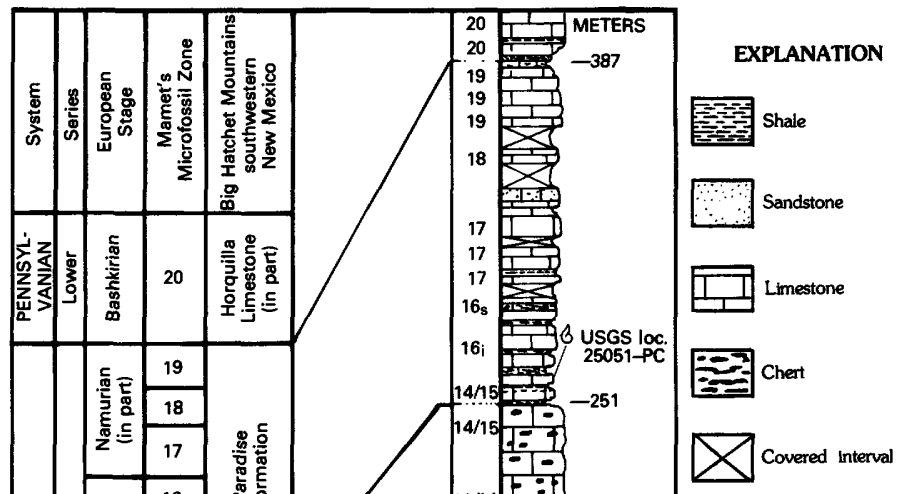

B Fossil

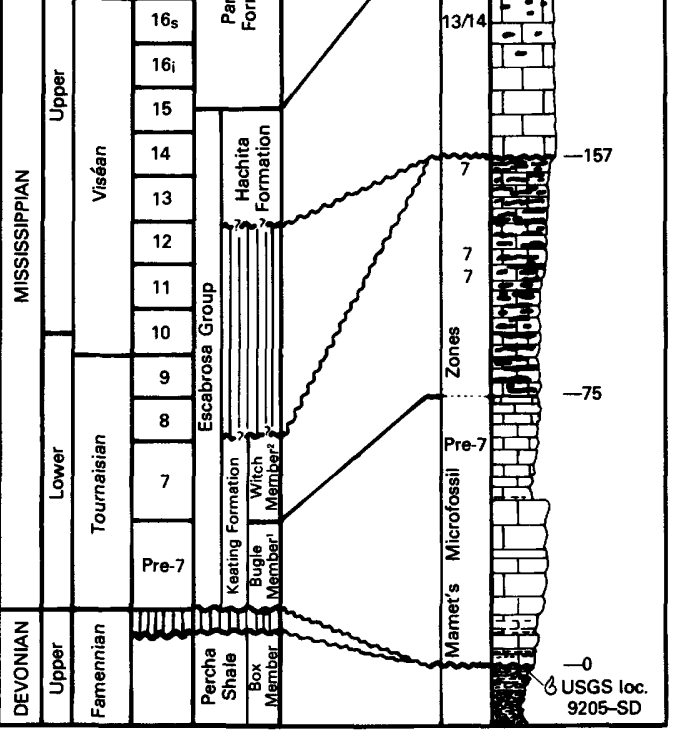

'Armstrong's (1962) member A

2Armstrong's (1962) member B

Figure 2.-Biostratigraphic and lithologic correlation diagram of Mississippian strata of the Big Hatchet Mountains, Hidalgo County, southwestern New Mexico. Note that the type Tournaisian in western Europe includes Zone 6. Mamet's microfossil zonation is from Sando and others (1969) and Armstrong and Mamet (1978).

Armstrong (1962, 1970) designated sec. 20, T. 16 S., R. 30 E. (Vanar quadrangle), on the southeast side of Blue Mountain, Chiricahua Mountains, southeastern Arizona, as the type section for the Keating and Hachita Formations. The location at Blue Mountain also includes Stoyanow's (1962) type section for the Paradise Formation (Upper Mississippian). 
The two informally named members $A$ and $B$ of the Keating Formation are here named the Bugle and Witch Members, respectively. The names are taken from Bugle Ridge and the Witch Well, published on the $1: 62,500$ scale Big Hatchet quadrangle map. The type sections for both members are in the El/2 sec. 30, T. 29 S., R. $15 \mathrm{~W}$., northeast side of the Big Hatchet Mountains, Hidalgo County, southwestern New Mexico (fig. 1). These two members are recognized in the Klondike Hills, Cedar Mountains, and Peloncillo Mountains of New Mexico and at Blue Mountain, Chiricahua Mountains, and Pedregosa Mountains of southeastern Arizona.

The Bugle Member (fig. 2) rests unconformably on the yellowish-gray shale and nodular limestone of the Box Member of the Percha Shale. A collection of brachlopods from the Box Member, less than a meter below the contact with the the Bugle Member, contains the following brachiopods identified by J. Thomas Dutro, Jr. (USGS 1oc. 9205-SD):

Schuchertella percha (Stainbrook)
Leioproductus
Sentosia praecursor (Stainbrook)
Cyrtospirifer kindlei (Stainbrook)
Cleiothyridina? sp.
Composita? sp.

Dutro (written commun., 1973) stated that this is clearly the fauna from the Box Member of the Percha Shale that was described by Stainbrook (1947) and is a fauna of probable middle Famennian (Late Devonian) Age.

The gray crinoidal-bryozoan-packstone of the Bugle Member rests with a sharp contact on the yellow-gray calcareous shale of the Box Member of the Percha Shale. The Bugle Member is $75 \mathrm{~m}$ thick and is massive-bedded bryozoan-echinoderm to ooid packstone and wackestone and argillaceous crinoidal-bryozoan packstone. The member has almost no chert. Armstrong (1962) reported a megafauna from 30 to $60 \mathrm{~m}$ above the base of the Bugle Member: brachiopods, Unispirifer balki Armstrong, Spirifer louisianens is Rowley, Brachythyris peculiaris (Shumard); rugose corals, Lithostrotionel la microstylum (White), L. 1ochmanae Armstrong, Homalophylites calceolus (White and Whitfield), and Rylstonia teres (Girty). Mamet found a microfossil assemblage of pre-Zone 7 age from 68 to $70 \mathrm{~m}$ above the base. Mamet's microfossil zonation, as defined in Sando, Mamet, and Dutro (1969, p. E12-E17) and Armstrong and Mamet (1978), is used in this report. The Bugle Member is late early to early middle Tournaisian (Early Mississippian) in age.

The base of the overlying Witch Member is placed at the lowermost occurrence of abundant nodular black chert. The Witch Member is $82 \mathrm{~m}$ thick. Nodular to lenticular, gray to yellowish-orange-gray chert makes up 15 to 35 percent of the member. Sedimentary features include fine ripple cross-laminations cut by numerous small worm burrows. The 
limestone is gray to dark gray and is composed to spiculitic-pelletoidbryozoan-ech inoderm-lime muds tone to wackestone and packstone. Imbrexia forbesi (Norwood and Patton) is the most abundant brachlopod in the upper half of the Witch Member (Armstrong, 1962), and Mamet found a microfossil assemblage of Zone 7 of the middle Tournaisian (Early Mississippian) for the upper $4 \mathrm{~m}$ of the Witch Member.

The contact between the dark-gray, chert-rich Witch Member and the overlying massive light-gray, chert-free, crinoidal-bryozoan wackestone to packstone of the Hachita Formation is abrupt. The Hachita Formation is $94 \mathrm{~m}$ thick.

Fossils are absent in the lower part of the Hachita Formation. The microfossils Brunsia spp. (Zones 14 and, 15) and the brachiopods Syringothyris subcuspidatus (Hal1) and Werria keokuk (Ha11) (Armstrong, 1962) occur 10 and 15 to $20 \mathrm{~m}$, respectively, below the top of the Hachita Formation. The top of the Hachita Formation is early late Viséan (Late Mississippian) in age.

The Paradise Formation has a gradational contact through 2 to $3 \mathrm{~m}$ with the underlying Hachita Formation. The Paradise Formation is $133 \mathrm{~m}$ thick and consists of gray to dusty yellow-gray to dusty greenish-gray limestone alternating with thin-bedded, calcareous shale and siltstone. The carbonate rocks, in beds 0.5 to $2 \mathrm{~m}$ thick, are typically lime mudstone brachlopod-bryozoan-molluscan wackestone and packstone and oold-foraminiferal packstone to grainstone.

In 1972 Armstrong collected a cephalopod fauna 4 m above the base of the Paradise Formation. These fossils were identified by Mackenzie Gordon, Jr. (written commun., 1973; USGS 10c., 25051-PC) as: Michelinoceras? sp., Brachycycloceras sp., Reticycloceras sp., Mitorthoceras perfilosum Gordon?, Girtyoceras sp., Goniatites americanus Gordon. Gordon commented "The Goniatites americanus Gordon Zone is the lowest of three zones characterized by the species of Goniatites and marks the top of the Meramecian Series in the midcontinental and western United States. It should occur in Mamet's microfossil Zone 15." Subsequently, Mamet found the Brunsia spp. microfossils of Zone 14-15 with the Goniatites. The base of the Paradise Formation in the Big Hatchet Mountains is no younger than Zone 15 . 
Mamet's microfossil Zones 15 through 19, Viséan and Namurian, were recognized in the Paradise section. The uppermost strata of the Paradise Formation are a pale yellow-gray foraminiferal-ooid grainstone, overlain by $1 \mathrm{~m}$ of gray nodular limestone in a gray shale. M. K. Elias (in Zeller, 1965, table 1) gave a megafossil list for the Paradise Formation of the Big Hatchet Mountains. The basal bed of the Pennsylvanian section is 1.5 to $2 \mathrm{~m}$ of light-brown quartz sandstone containing imprints of plant remains. This sandstone formation is in turn overlain by massive foraminiferal-ooid-brachiopod wackestone that contains brown-gray lenticular nodular chert. The microfossils in the limestone are Zone 20, Pennsylvanian, Bashkirian, in age. The hiatus between the Mississippian and Pennsylvanian Systems in the Big Hatchet Mountains, if present, represents a very brief time, and the section may be continuous.

\section{REVISED AGES OF CAMBRIAN AND ORDOVICIAN FORMATIONS OF THE CONESTOGA VALLFY NEAR YORK AND LANCASTER, SOUTHEASTERN PENNSYLVANIA}

By Gregory S. Gohn ${ }^{1}$

The Conestoga Valley, located along the northern edge of the Pennsylvania Piedmont ( $f(g .3)$, contains a sequence of carbonate and siliciclastic rocks that are broadly correlative with the Cambrian and Ordovician rocks to the north and west in the Blue Ridge and Great Valley area. Metamorphic grade and structural complexity increase abruptly to the southeast in the Piedmont, and the Conestoga Valley is one of the easternmost locations in the central and southern Appalachians in which relatively undeformed, fossiliferous, Paleozoic sedimentary rocks can be studied.

The stratigraphy of the Cambrian and Ordovician carbonate rocks of the Conestoga Valley was originally formalized in a series of articles by George W. Stose and Anna Jonas Stose (Stose and Jonas, 1922; Jonas and Stose, 1926; Jonas and Stose, 1930; Stose and Jonas, 1939; Stose and Stose, 1944). In later years, Melsler and Becher $(1968,1971)$ remapped part of the Conestoga Valley and defined three structural-stratigraphic belts of carbonate rocks; the Lititz and Mount Joy belts north of the Hellam Hills and Chickies Ridge and the Welsh Mountain uplifts (fig. 3), and the Lancaster belt south of the uplifts. Meisler and Becher (1968) also revised the stratigraphy of the Upper Cambrian and Ordovician rocks (Elbrook Limestone, Conococheague Group, Beekmantown Limestone, and

1/U.S. Geological Survey, Reston, Va. 


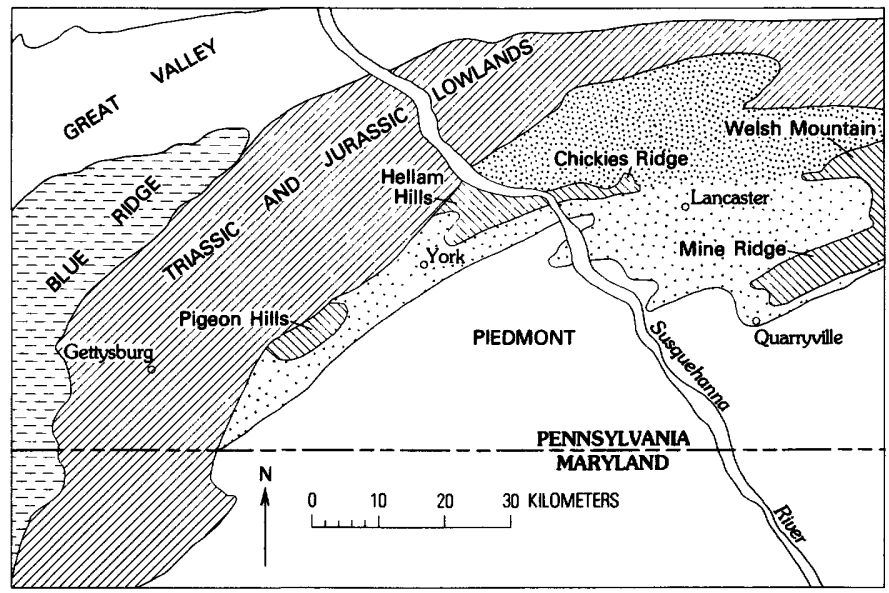

Figure 3.-Location of physiographic provinces in southeastem Pennsylvania near York and Lancaster Structural and stratigraphic belts of Cambrian and Ordovician carbonate rocks in the Conestoga Valley defined by Meisler and Becher (1971) are shown in heavy (Lititz and Mount Joy belts) and light (Lancaster belt) stipple. The Lancaster belt is here redefined to include the carbonate rocks around York. Basement uplifts around the Conestoga Valley include the Pigeon Hills, the Hellam Hills and Chickies Ridge, Welsh Mountain, and Mine Ridge.

"Cocalico basal limestone" of Jonas and Stose, 1930) of the Lititz and Mount Joy belts but accepted the stratigraphy of Jonas and Stose (1930) for the Lancaster belt. Subsequent studies of the lithostratigraphy and biostratigraphy of the rocks of the Lancaster-York belt (fig. 3) by Campbel1 (1969, 1971), Yochelson (1970), and Gohn (1976) have shown the basic lithostratigraphic framework of Jonas and Stose to be correct, but they have also pointed out the need for revision of the age assignments of several formations (table 1 ).

Jonas and Stose had defined three Informal members in the Kinzers Formation and assigned them to the Lower Cambrian Series (Stose and Stose, 1944). Campbell (1971) reported Middle Cambrian fossils ("Ogygopsis shale" fauna) from the upper member of the Kinzers Formation in Lancaster County. These fossils, in conjunction with the we11-known Early Cambrian faunas of the Kinzers' lower and middle members and the underlying Vintage Dolomite (Resser and Howell, 1938; Stose and Stose, 1944; Yochelson, 1970) indicate that the Kinzers (table 1) belongs to both the Lower Cambrian (lower, middle, and basal part of upper members) and the Middle Cambrian (upper part of upper member). 
Table 1.-Stratigraphic sections of the carbonate rocks of the Lancaster-York belt of the Conestoga Valley, southeastern Pennsylvania.

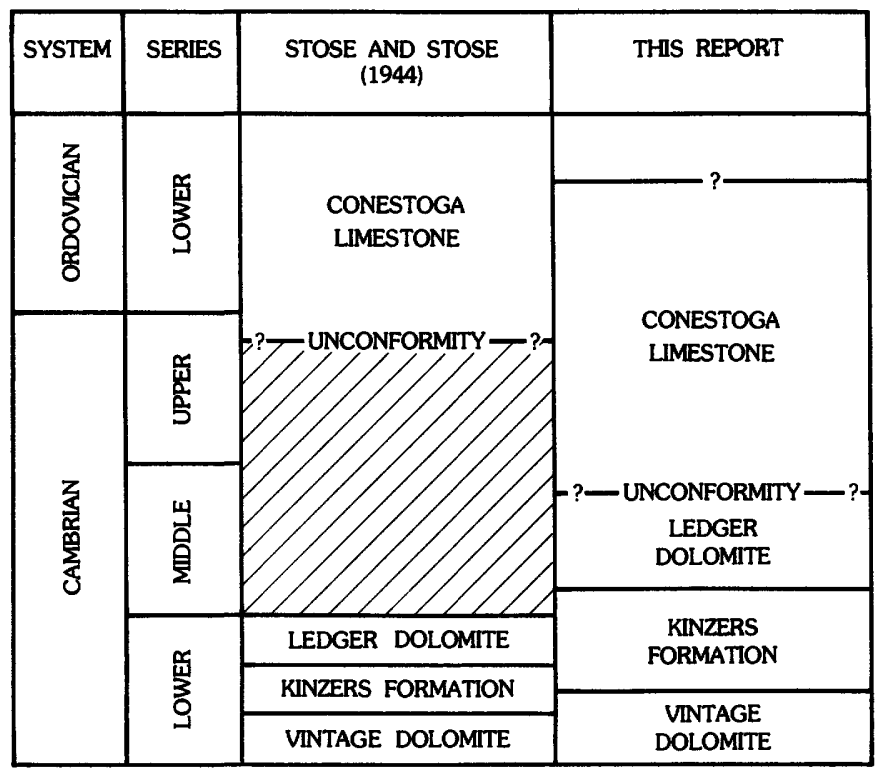

Although no fossils have ever been found in the Ledger Dolomite, Jonas and Stose assigned it to the Lower Cambrian (table 1) on the basis of regional stratigraphic relationships (Stose and Stose, 1944, p. 3334). However, the presence of Middle Cambrian fossils in the underlying Kinzers Formation and the position of the Ledger unconformably beneath Middle(?) Cambrian fossils in the Conestoga Limestone (see below) require that the Ledger be considered Middle Cambrian in age.

Until recently, no stratigraphically diagnostic fossils had been found in the Conestoga Limestone. Early reports of fossils in the Conestoga by Jonas and Stose were incorrect as the specimens were later shown to be from the Kinzers Formation (Stose and Stose, 1944, p. 37). Brachlopods from near the base of the Conestoga west of Lancaster reported to be of Early Ordovician age (D.U. Wise in Campbell, 1969, p. 35) could actually be identified only as "...most $\overline{11 k e l y}$ either Cambrian or Lower Ordovician forms" (R.B. Neuman, unpub. data, 1964). 
The generally accepted Early Ordovician age of the Conestoga Limestone is based in large part upon the presence of Early Ordoviclan mollusks (Stose and Stose, 1944; Richards, 1958) in limestone tentatively correlated with the Conestoga from outcrops located well east of Lancaster at Henderson Station. The correlation of those beds with the Conestoga Limestone around York and Lancaster remains speculative, and the assignment of an Early Ordovician age to the Conestoga on the basis of these fossils is at best tentative.

Trilobites and inarticulate brachiopods from a single outcrop at the base of the Conestoga near York are fragmented and tectonically distorted. Tentative identification of several genera by Michael $\mathrm{E}$. Taylor (written commun., 1977) suggests a Middle Cambrian age for that fauna. The very poor preservation of the fossil material prohibits conclusive statements about the age.

Biostratigraphic data for the Conestoga therefore remain sparse and inconclusive. The best age assignment for the Conestoga Limestone at present (table 1) is Middle(?) Cambrian to Early Ordovician(?). 


\section{THE SANDY SPRINGS GROUP AND RELATED ROCKS IN THE GEORGIA PIEDMONT; NOMENCLATURE AND STRATIGRAPHY}

By Michael W. Higgins ${ }^{1}$ and Keith I. McConnel1 ${ }^{2}$

Northwest of the Brevard Zone, in the Georgia Piedmont, is a series of long, linear, northeast-trending ridges generally held up by quartzite; the valleys and slopes between the ridges are underlain by schist, gneiss, and amphibolite. The topography of this area is greatly different from that to the southeast and to the northwest (Clark and Zisa, 1976; fig. 4, this paper). The rocks of this terrane form a distinct structural and stratigraphic sequence. In 1966, Higgins (also 1968) used the informal name "Sandy Springs Sequence" for these rocks. Unfortunately, he capitalized "Sequence," erroneously implying a formal name. Since then, other workers in the area have used the name "Sandy Springs Sequence" in a more-or-less formal way. "Sequence" is not a recognized stratigraphic name (American Commission on Stratigraphic Nomenclature, 1970) and should be abandoned.

The purpose of this paper is to formalize the name Sandy Springs Group, to define the group and its constituent formations and members of formations, and to propose correlations with units along strike.

\section{SANDY SPRINGS GROUP}

The Sandy Springs Group is here formally named for, and its type area given as, the town of Sandy Springs, Ga. (see U.S. Geological Survey, Sandy Springs, Georgia, $71 / 2 \mathrm{~min}$. topographic quadrangle), where the name "Sandy Springs Sequence" was used (Higgins, 1966, 1968), and where most of the formations that make up the group are fairly well exposed. The group consists of (ascending): Powers Ferry Formation (with its Mableton Amphibolite Member), Chattahoochee Palisades Quartzite, Factory Shoals Formation, and Rottenwood Creek Quartzite. The age of the group is unknown but is probably late Precambrian and (or) early Paleozoic. The thickness of the group (apparent thickness because of folding), its constituent formations, and the apparent stratigraphic relations are shown in figure 5. Rocks of the Sandy

$1 /$ U.S. Geological Survey, Atlanta, Ga. 2/Georgia Geological Survey, Atlanta, Ga. 


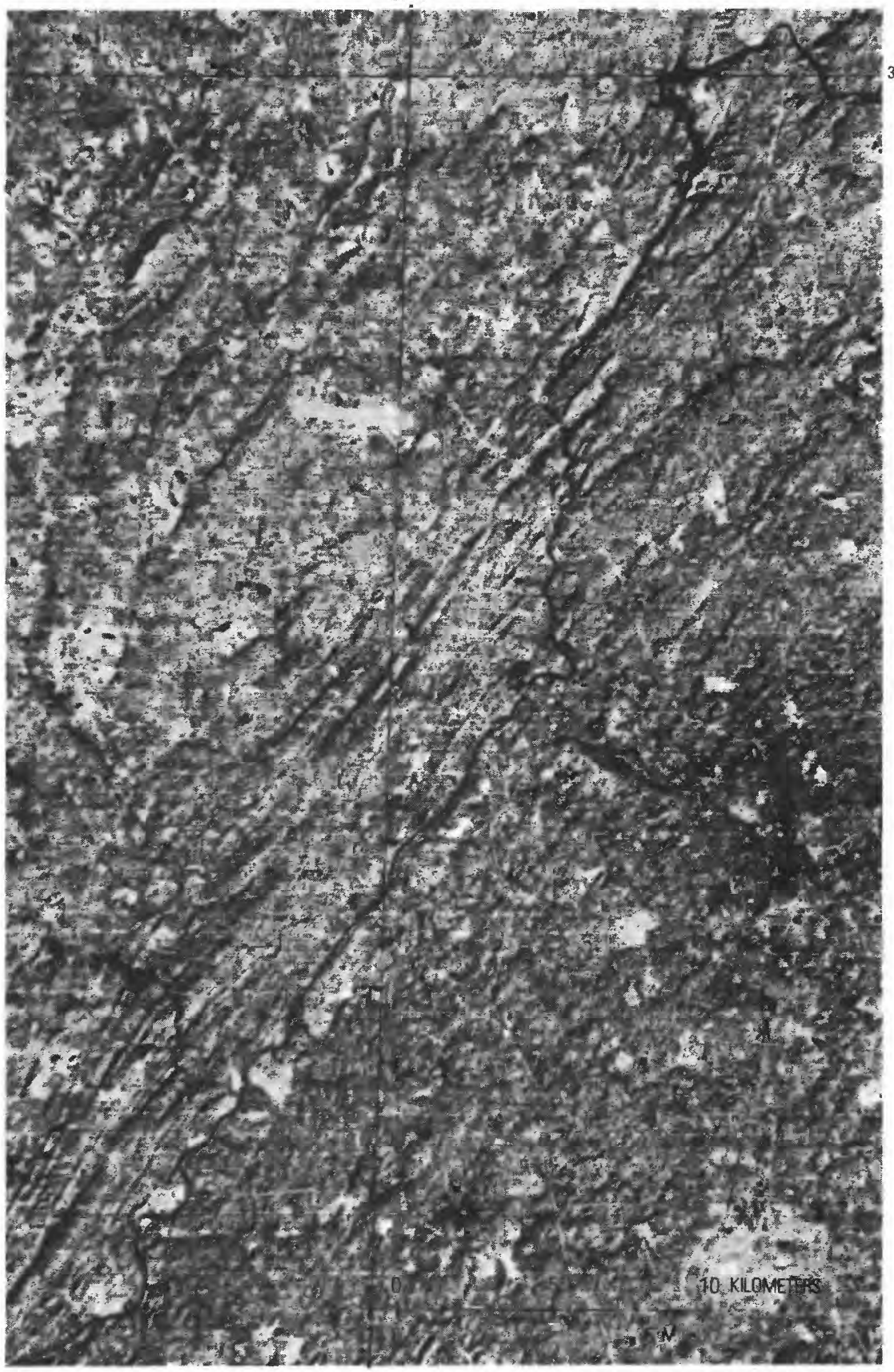

Figure 4.-Enlarged Landsat image (band 7) showing the quartzite ridges of the Sandy Springs Group. 


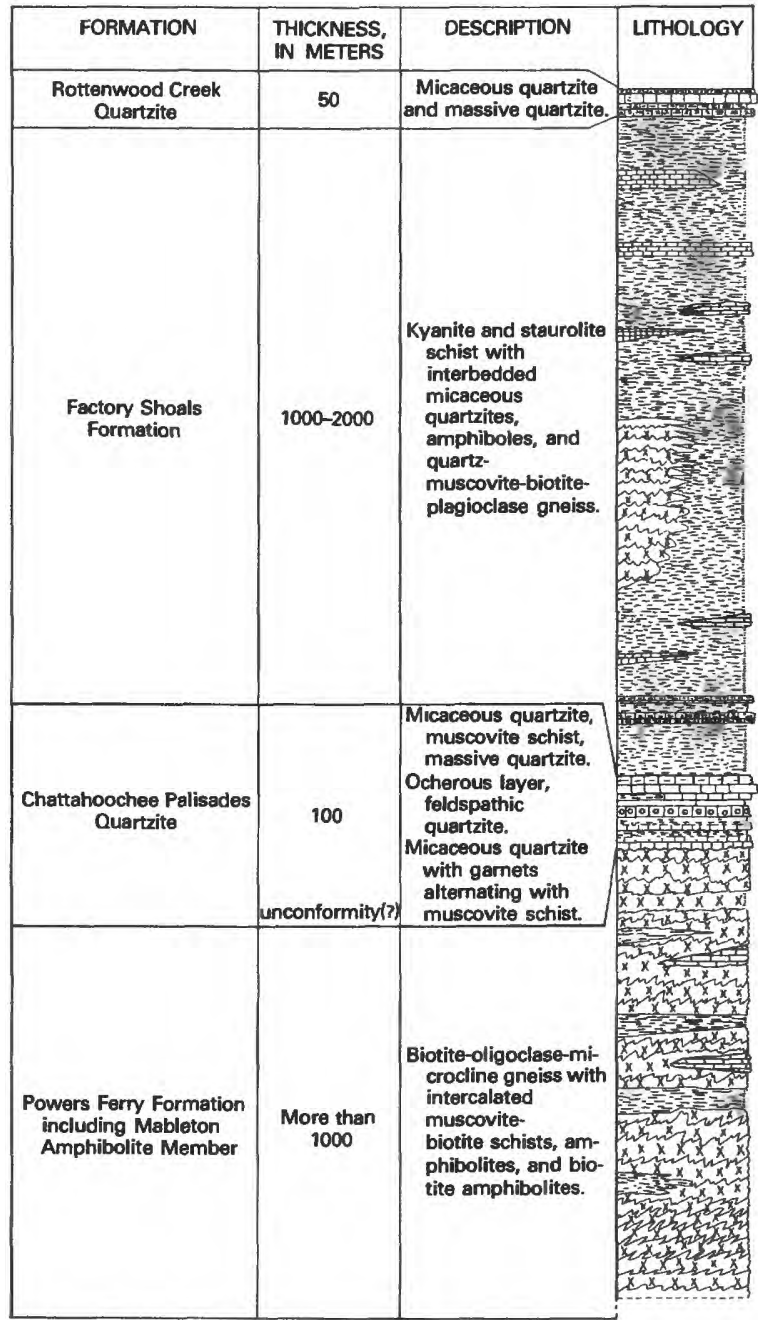

Figure 5.-Diagrammatic stratigraphic column of the Sandy Springs Group. 
Springs Group have now been mapped as far northeast as South Carolina (f1g. 6; Higgins, 1968; Murray, 1973, and unpub. data, 1975; Hatcher, 1971,1974 ) and as far southwest as Alabama (Crawford and Med Iin, 1974). Across strike, they extend from the Brevard Zone as far as $30 \mathrm{~km}$ (19 $\mathrm{mi})$ to the northwest (fig. 6). Measured sections through parts of the group are given in Higgins (1965).

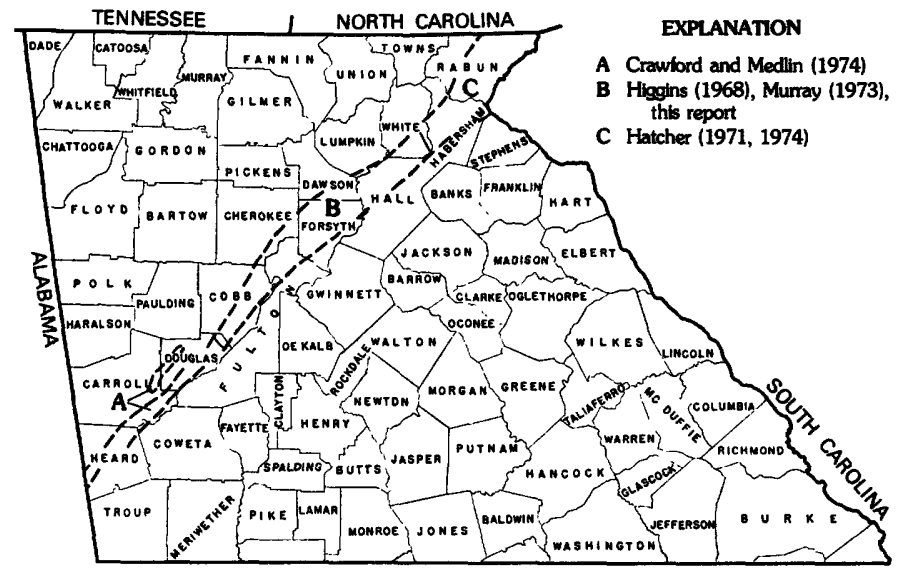

Figure 6.-County outline map of part of Georgia showing known outcrop area (inside dashed lines) of the Sandy Springs Group. Letters indicate mapped areas.

Crawford and Mediin (1974) proposed many informal names for units that they mapped in the "Sandy Springs Sequence." These names are, for the most part, not adopted in this paper because they were informal and were published only in a field trip guidebook and because we prefer to use names for geographic localities that are as near as possible to the type area for the group name.

\section{POWERS FERRY FORMATION}

The Powers Ferry Formation is here named for, and 1 ts type area given as, Powers Ferry (now called Powers Ferry Landing, where Powers Ferry once crossed the Chat tahoochee River; U.S. Geological Survey, Sandy Springs, Georgia, $71 / 2 \mathrm{~min}$. topographic quadrangle), where the rocks are well exposed in new cuts in the Powers Ferry Landing shopping 
center and of fice park. The Powers Ferry Formation consists of the rocks that Higgins $(1966,1968)$ called "the gneiss-schist-amphibolite unit" and of other lithologies now mapped along strike by Crawford and Medlin (1974), Murray (1973), Hatcher (1971, 1974), and McConnell (unpub. data, 1977; also see McConnell and Abrams, in press). A type section of these rocks is exposed along Anneewakee Creek and along the road leading to Camp Anneewakee (U.S. Geological Survey, Campbellton, Georgia, 7 1/2 min. topographic quadrangle).

As mentioned above, the Powers Ferry Formation consists mainly of intercalated gneiss, schist, and amphibolite in decreasing order of abundance. One large mappable amphibolite unit is named below.

The gneiss in the Powers Ferry Formation is generally a mediumgrained gray, discontinuously striped muscovite-biotite-microclinequartz-oligoclase (about An 12) gneiss, locally having pink microcline augen as long as $7 \mathrm{~cm}(23 / 4 \mathrm{in})$. In places, it contains small amounts of epidote, opaque minerals, and garnet. Concordant quartz-microcline pegmatite is fairly common, and pods and discontinuous layers of muscovite-biotite-quartz schist, amphibolite, and hornblende schist are common and locally constitute most of the formation. Parts of the gneiss resemble massive quartzite. Some biotite-quartz-plagloclase gneiss (probably metagraywacke) occurs within the formation, and specularite quartzite and layered amphibolite are mappable for short distances.

The Powers Ferry Formation is apparently the oldest formation in the Sandy Springs Group. The base of the formation has not been seen because the Powers Ferry Formation is present only in the cores of antiforms. It is in sharp contact, possibly unconformably, with the overlying Chattahoochee Palisades Quartzite (fig. 5). This contact is well exposed in cuts of the Louisville and Nashville Rail road on the flanks of the Vinings antiform (Vinings anticline of Higgins, 1966, 1968) near Vinings, Ga. (U.S. Geological Survey, Northwest Atlanta, Georgia, $71 / 2 \mathrm{~min}$. topographic quadrangle). The actual thickness of the Powers Ferry Formation is unknown because the base is not exposed and because of isoclinal folding. On the basis of distribution shown on geologic map, the formation is estimated to be more than $1,000 \mathrm{~m}(3,290$ ft) thick.

MABLETON AMPHIBOLITE MEMBER

Layered hornblende-plagioclase amphibolite within the Powers Ferry Formation is here named (and it type area given) the Mableton Amphibolite Member for exposures along and north of Fountain Road just northeast of Mableton (U.S. Geological Survey, Mableton, Georgia, 7 1/2 
min. topographic quadrangle; McConnell, unpub. data, 1977). Higgins (1968) showed two belts of disconnected layered amphibolite within the Powers Ferry (his gneiss-schist-amphibolite unit), but McConnell's recent work has shown that they are connected. The amphibolite appears to be about $500-700 \mathrm{~m}(1,640-2,300 \mathrm{ft})$ thick on the basis of distribution shown on geologic map.

\section{CHATTAHOOCHEE PAL IS ADES QUARTZITE}

The Chattahoochee Palisades Quartzite is here named for, and its type area given as, the Palisades of the Chattahoochee River in Chattahoochee Palisades State Park (U.S. Geological. Survey, Sandy Springs, Georgia, $71 / 2$ min topographic quadrangle), where 1 torms cliff outcrops (see Higgins, 1968, lower quartzite unit). It is commonly a massive white, yel lowish, or bluish, sugary to vitreous quartzite containing accessory mica and elongated garnets. Locally it shows graded bedding, but more commonly beds 0.3-1.2 m (1-4 ft) thick are interlayered with feldspathic quartzite and muscovite schist. Along strike, variations to quartzose mica schist also are seen that are due to sedimentary facies changes. The bottom of the quartzite is in sharp, possibly unconformbale, contact with the underlying Powers Ferry

Formation. Within a few meters ( $a$ few feet), the top grades into rocks of the Factory Shoals Formation. On the basis of distribution shown on geologic map, the quartzite appears to be about $100 \mathrm{~m}$ ( $329 \mathrm{ft}$ ) thick, but is locally absent probably because of nondeposition.

\section{FACTORY SHOALS FORMATION}

The Factory Shoals Formation is here named for, and its type area given as, exposures along Sweetwater Creek at Factory Shoals (U.S. Geological Survey, Ben Hill, Georgia, $71 / 2$ min. topographic quadrangle; see McConnell and Abrams, in press). It includes the rocks mapped by Higgins (1968) as his aluminous schist unit. The Factory Shoals is commonly a light-gray lustrous garnet-biotite-oligoclase-muscovitequartz schist locally containing kyanite or staurolite. It also contains layers of quartz muscovite schist, thinly bedded red micaceous quartzite, muscovite-biotite-plagioclase metagraywacke, and graphiticmuscovite-quartz schist. Locally metagraywacke predominates. It is in gradational contact (see above) with the Chat tahoochee Palisades Quartzite at its base, and grades over a short distance into the Rottenwood Creek Quartzite at its top (fig. 5). On the basis of distribution shown on geologic map (Higgins, 1968; McConnell, unpub. data, 1977), the formation appears to be $1,000-2,000 \mathrm{~m}(3,290-6,570 \mathrm{ft})$ thick. 


\author{
ROTTENWOOD CREEK QUARTZITE
}

The Rottenwood Creek Quartzite is here named for, and its type area given as, excellent exposures along Rottenwood Creek about 1,000 m $(3,290 \mathrm{ft})$ southeast of Akers Mill Road (U.S. Geological Survey, Sandy Springs, Ga., $71 / 2 \mathrm{~min}$. topographic quadrangle). It is commonly a massive muscovite-bearing quartzite containing small amounts of plagioclase, epidote, and opaque minerals (Higgins, 1966). It is the uppermost unit of the Sandy Springs Group. At the base, it grades over a short distance into the Factory Shoals Formation. It crops out along the axial traces of synforms and is absent in many places owing to erosion or nondeposition(?). On the basis of distribution shown on maps (Higgins, 1968), it is as much as $50 \mathrm{~m}$ (164 ft) thick.

\title{
RELATED ROCKS
}

\section{LONG ISLAND CREEK GNEISS}

The Long Island Creek Gneiss is here named for, and its type area given as, exposures on the southeast side of Long Island Creek near and along Roswell Road (U.S. Geological Survey, Sandy Springs, Ga., 7 1/2 min. topographic quadrangle; Higgins, 1968). It is in fault contact with all other adjacent rocks; therefore, its stratigraphic position and age are unknown. It is named here because it forms a mappable boundary of the Sandy Springs Group. The Long Island Creek Gneiss is typically a dark-gray epidote-biotite-plagioclase gneiss. It generally contains euhedral crystals of sphene and a few tiny garnets. It weathers to a massive yellow saprolite. Good exposures of typical Long Island Creek Gneiss are seen in cuts for driveways at the new I.B.M. facility on U.S. Highway 41 just southeast of the Chattahoochee River (U.S. Geological Survey, Northwest Atlanta, Ga., $71 / 2 \mathrm{~min}$. topographic quadrangle). The thickness of the Long Island Creek Gneiss is unknown.

\section{YELLOW DIRT GNEISS}

Crawford and Med1in (1974, p. 11) informally named the "Yellow Dirt gneiss" for the community of Yellow Dirt, Heard County, Ga., (U.S. Geological Survey, Lowell, Georgia, 7 1/2 min. topographic quadrangle). The gneiss is commonly a fine-to-medium-grained, biotite-epidotemuscovite-quartz-plagioclase-microcline rock that generally has strong 
cataclastic textures (blastomylonite and mylonite gneiss, see Higgins, 1971). It bounds the Sandy Springs Group for long distances and is here proposed as a formal formation with the type locality that of Crawford and Medlin (1974; see above). The gneiss is estimated to be 75-240 m $(250-800 \mathrm{ft}$ ) thick (see Crawford and Medlin, 1974). Because it is fault-bounded, its stratigraphic position and age are unknown.

\section{CORRELATIONS}

Table 2 gives the correlation that Crawford and Mediln (1974) proposed between the "Sandy Springs Sequence" of Higgins (1966, 1968) and their informal units and between these two "sequences" and the formal group proposed in this paper. To the northeast, the rocks of the Sandy Springs Group are probably correlative, as indicated, with some of the rocks in the Tallulah Falls area (Higgins, 1966; Hatcher, 1974).

Table 2.-Correlation chart of Sandy Springs Group with other informal units in northwestern Georgia.

\begin{tabular}{|c|c|c|c|}
\hline \multicolumn{4}{|c|}{$\mathbf{W}$} \\
\hline $\begin{array}{l}\text { "Sandy Springs } \\
\text { Sequence" }\end{array}$ & $\begin{array}{l}\text { "Sandy Springs } \\
\text { Sequence" }\end{array}$ & $\begin{array}{l}\text { Sandy Springs } \\
\text { Group }\end{array}$ & $\begin{array}{l}\text { Tallulah Falls } \\
\text { Formation }\end{array}$ \\
\hline $\begin{array}{c}\text { Crawford \& Medlin } \\
\text { (1974) }\end{array}$ & $\begin{array}{c}\text { Higgins } \\
(1966,1968)\end{array}$ & This paper & $\begin{array}{l}\text { Hatcher } \\
\text { (1974) }\end{array}$ \\
\hline $\begin{array}{l}\text { Mt. Olive Church } \\
\text { (schist) }\end{array}$ & Not present & Not present & Not present \\
\hline Adamson quartrate & Upper quartzite & $\begin{array}{l}\text { Rottenwood Creek } \\
\text { Quartzlte }\end{array}$ & $\begin{array}{l}\text { Quartite-schist member } \\
\text { and graywecke schist } \\
\text { member(?) }\end{array}$ \\
\hline Backbone schist & \multirow{3}{*}{ Aluminous schist } & \multirow{3}{*}{$\begin{array}{l}\text { Factory Shoals } \\
\text { Formation }\end{array}$} & \multirow{3}{*}{$\begin{array}{l}\text { Garnet-aluminous-schist } \\
\text { member }\end{array}$} \\
\hline $\begin{array}{l}\text { Anneewakee graphitic } \\
\text { schist-quartite }\end{array}$ & & & \\
\hline $\begin{array}{l}\text { Sparks Reservotr } \\
\text { (schist and gneiss) }\end{array}$ & & & \\
\hline Dry Creek quartztte & Lower quartalte & $\begin{array}{l}\text { Chattahoochee } \\
\text { Palisades Quartzlte }\end{array}$ & Not defined \\
\hline $\begin{array}{l}\text { Chapel Hil Church } \\
\text { (gneiss and schist) }\end{array}$ & \multirow{3}{*}{$\begin{array}{l}\text { Gnelss-schist- } \\
\text { amphibolite }\end{array}$} & \multirow{3}{*}{$\begin{array}{l}\text { Powers Ferry Formation } \\
\text { Including Mabletion } \\
\text { Amphibolite Member }\end{array}$} & \multirow{3}{*}{$\begin{array}{l}\text { Graywacke-schist } \\
\text { amphibolite member }\end{array}$} \\
\hline $\begin{array}{l}\text { Mt. Vemon Church } \\
\text { graphitic schist- } \\
\text { quartzlte }\end{array}$ & & & \\
\hline $\begin{array}{l}\text { Mt. Vernon Church } \\
\text { schist }\end{array}$ & & & \\
\hline
\end{tabular}




\title{
RESTRICTION AND RENAMING OF THE NERUOKPUK FORMATION, NORTHEASTERN ALASKA
}

\author{
By Hillard N. Reişer, Donald K. Norris, \\ J. Thomas Dutro, Jr?, and William P. Brosge
}

E. de K. Leffingwell (1919, p. 103-105, p1.11) mapped a distinctive quartzite schist from the Canning River eastward to the Jago River. He described the schist, which he considered pre-Carboniferous, as being typically developed at Lake Peters and named it the Neruokpuk Schist, stating that the name is taken from the Eskimo name for Lakes Peters and Schrader. And indeed, Lake Peters, the southern of these two joined lakes, is surrounded by mountains that are underlain by this quartzite schist.

Subsequent mapping by geologists of the U.S. Geological Survey in and east of its type area expanded the Neruokpuk to include additional rock types (Brosge and others, 1962; Reed, 1968; Reiser, 1970; Sable, 1977), and its name was revised to Neruokpuk Formation. In 1972, its age was revised to Precambrian, Cambrian, and post-Cambrian preMississippian on the basis of marine fauna from some parts (Dutro and others, 1972). The quartzite schist was designated a Precambrian member of the Neruokpuk, and 11 other lithologically distinct members were described.

Geologists working in northeastern Alaska and in the adjoining northwestern part of Canada have found the name Neruokpuk Formation confusing as now applied because of the great variety of rock types and the extensive age range of the unit.

To remedy the present confusion, we propose that (1) the name Neruokpuk be again restricted to the rocks lithologically correlative and homotaxial with the type Neruokpuk as originally described by Leffingwell, and (2) that the name Neruokpuk Quartzite be used to reflect this restricted usage.

$1 /$ U.S. Geological Survey, Menlo Park, Calif. $\frac{2}{3} /$ Geological Survey of Canada, Calgary, Alberta, Canada. $\underline{3} /$ U.S. Geological Survey, Washington, D.C. 
According to this new usage, basement rocks in the wells drilled in northeastern Alaska should no longer be referred to the Neruokpuk unless they sufficiently resemble the quartzite schist at its type locality. A lithologic unit found in the wells that cannot be correlated with rock units recognized in surface exposures perhaps should have its own nomenclature.

\title{
AGE' OF THE METALINE LIMESTONE OR FORMATION IN NORTHEASTERN WASHINGTON
}

\author{
By John E. Repetski ${ }^{1}$
}

Conodont and vertebrate evidence, recently discovered, indicates that the top of the Metaline Limestone (or Formation) in Stevens County, northeastern Washington, probably is Late Cambrian or Early Ordovician in age. A sample containing a few poorly preserved conodont fragments and a few pieces of the oldest known fish, Anatolepis, was collected and labeled: "In place from upper 1.0 foot of Metaline Dolomite" by M. E. Taylor (U.S. Geological Survey, Denver, Colo.) and J. E. Schuster (Geology and Earth Resources Division, Olympia, Wash.) [USGS fossil locality no. 8667-Co]. The conodont fragments are not identifiable, but they are of a type that is not known to occur lower than the Upper Cambrian (Franconian Stage). Anatolepis is known, thus far, to have an age range of Late Cambrian (Ptychaspis-Prosaukia [trilobite] Zone) to late Early Ordovician (Arenigian to Canadian) or possibly earliest Middle Ordovician (late Arenigian or earliest Llanvirnian to Whiterockian). On the basis of this evidence, and until additional fossils are recovered, I recommend that the age of the Metaline be considered as Middle to Late(?) Cambrian and Early Ordovician(?).

1/U.S. Geological Survey, Washington, D.C. 
AGES OF THE LEE, BREATHITT, CASEYVILLE, TRADEWATER, AND STURGIS FORMATIONS IN KENTUCKY

By Charles L. Rice ${ }^{1}$

The boundary between the Lower and Middle Pennsylvanian Series in the Appalachian and Eastern Interior basins in Kentucky has generally been considered to be equivalent to the Morrowan-Atokan boundary of the midcontinent region. Unfortunately, however, new stratigraphic data indicate that these boundaries do not correspond; therefore, the ages of several Lower and Middle Pennsylvanian units in Kentucky need to be reassigned. In addition, new paleontological data indicate that the Sturgis Formation of western Kentucky extends from Middle Pennsylvanian to Early Permian age.

The top of the Lower Pennsylvanian Series in the proposed Pennsylvanian System stratotype section in West Virginia is placed at a marked change in lithology between resistant quartzose sandstone of the New River Formation and nonresistant shale and sandstone in the overlying Kanawha Formation (Englund and others, 1977). Although this boundary is equivalent in age to that between the Lee Formation and overlying Hance Formation (the lowest formation of the Breathitt Group) in the Cumberland overthrust block of eastern Kentucky, the Lee Formation intertongues with the Breathitt Formation northwestward, and the top of the Lee rises stratigraphically an appreciable amount in that direction (Englund, 1961, p. 69). Figure 7 shows the age relations of some tongues of the Lee Formation along the Pottsville escarpment (the western edge of the Appalachian basin) and the Lee Formation of the Cumberland overthrust block in eastern Kentucky.

Palentological data useful in establishing the postion of the boundary between the Lower and Middle Pennsylvanian Series in areas other than that of the proposed Pennsylvanian stratotype are sparse. However, Robert Kosanke (oral commun., 1978) demonstrated that the top of the range $z$ one of the spore Schulzopora rara of Mississippian to Middle Pennsylvanian age occurs in the midde part of the Hance Formation in the Cumberland overthrust block, near the base of the Corbin Sandstone Tongue of the Lee Formation in the Pottsville escarpment, and in the upper part of the Caseyville Formation in western Kentucky. Therefore, the Lee, Breathitt, and Caseyville Formations are all Early and Middle Pennsylvanian in age in Kentucky.

1/U.S. Geological Survey, Reston, Va. 


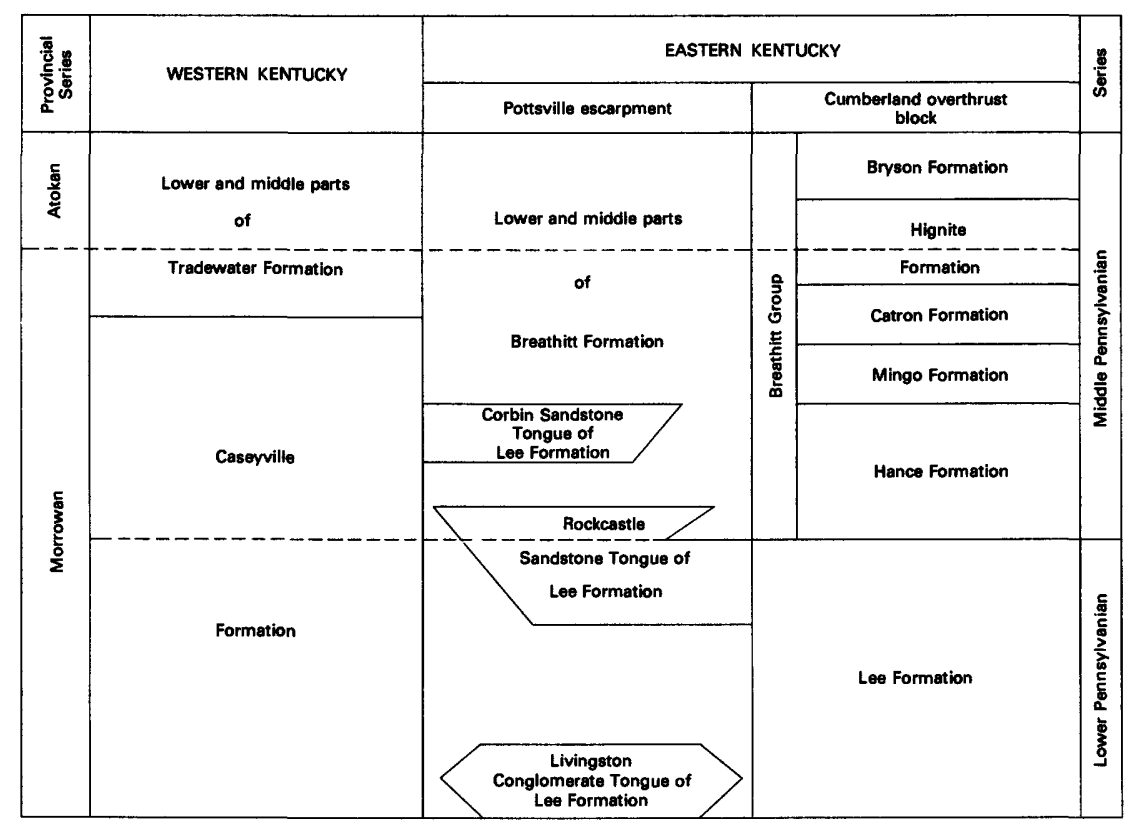

Figure 7.-Chart showing general age relations of some Lower and Middle Pennsylvanian units in Kentucky.

The boundary between the Morrowan and Atokan Series in eastern Kentucky has been tentatively placed in the middle part of the Breathitt Formation (Group) in eastern Kenutcky, between the Kendrick Shale of Jillson (1919), Morrowan in age, and the Magoffin Member, Atokan in age (Mackenzie Gordon, Jr., written commun., 1976). In western Kentucky, Douglass (written commun., 1977) identified fusulinids of early Atokan age in the middle part of the Tradewater Formation. Therefore, the Lee and Caseyville Formations are Morrowan in age, and the Breathitt Formation (Group) and probably the Tradewater Formation contain strata of Morrowan as well as Atokan age.

Studies of fusulinids from limestone of the Sturgis Formation of western Kentucky (Douglass, written commun., 1977) indicate that the boundary between the Middle and Upper Pennsylvanian Series occurs between the Madisonville Limestone Member (below) and the Carthage Limestone Member (above); this boundary is generally considered to correspond to that between the Des Moinesian and Missourian Series. Fusulinids of Early Permian age from drill core samples in the Bordley quadrangle also occur in the uppermost part of the Sturgis Formation in a conformable sequence of shale and limestone. Therefore, the Sturgis Formation extends from Middle Pennsylvanian to Early Permian age. 
CORAL ZONES AND PROBLEMS OF MISSISSIPPIAN STRATIGRAPHY IN THE WILLISTON BASIN, MONTANA AND NORTH DAKOTA ${ }^{1}$

By William J. Sando ${ }^{2}$

Study of Mississippian corals from the Madison Group in seven well cores from the Williston basin of Montana and North Dakota indicates that coral zones are useful for correlation of subsurface sections with outcrop sections and that they are more useful for correlation within the Williston basin subsurface than previously thought. The distribution of corals in the Charles Formation and Mission Canyon Limestone indicates that the Charles is a time-transgressive unit of late Osagean to early Meramecian age and is partly equivalent to the Mission Canyon Limestone of outcrop. The base of the Charles transgresses the Osagean-Meramecian boundary, ascendj ng basinward in the well cores studied. Use of the Charles Formation should be restricted to the Williston basin subsurface. The occurrence of corals indicates that the Charles is separated from the overlying Kibbey Formation (Chesterian) by a disconformity that represents an erosion interval ranging from middle Meramecian into early Chesterian.

1/From Sando, W. J., 1978, Coral zones and problems of Mississippian stratigraphy in the Williston basin, in Montana Geol. Soc., Williston Basin Symposium, Sept. 24-27, 1978, Billings, Mont., Proc.: p. 231-237. $2 /$ U.S. Geological Survey, Washington, D.C. 
TWIN RIVER GROUP (UPPER EOCENE TO LOWER MIOCENE)--DEFINED TO INCLUDE THE HOKO RIVER, MAKAH, AND PYSHT FORMATIONS, CLALLAM COUNTY, WASHINGTON

By Parke D. Snavely, Jr., Alan R. Niem, ${ }^{1}$ and James E. Pearl ${ }^{1}$

This report revises the nomenclature and stratigraphic rank of the Twin River Formation (upper Eocene to lower Miocene), as defined by Arnold and Hannibal (1913) and redefined by Brown and Gower (1958), that crops out in the north-central part of the Olympic Peninsula, Wash. (fig. 8). The Twin River Formation is herein raised to group rank because the three members defined by Brown and Gower (1958) are thick and distinct rock-stratigraphic bodies that have been mapped along strike for more than $100 \mathrm{~km}$ by Brown and others (1960), Gower (1960), and Parke D. Snavely, Jr., Norman S. MacLeod, and James E. Pearl (written commun., 1974; cited in Tabor and Cady, 1978), thus establishing their formational rank (American Commission on Stratigraphic Nomenclature, 1952).

The Twin River Group consists of three new formations that are named and briefly described in this report. These new formations are the Hoko River, Makah, and Pysht Formations and correlate with the lower, middle, and upper members of the Twin River Formation, respectively, as defined by Brown and Gower (1958) in their type locality along Deep Creek (figs. 8 and 9). The type localities and reference sections used to define the three new formations in the Twin River Group that are described in this report are shown on figure 8 . These new formations are briefly described from oldest to youngest.

HOKO RIVER FORMATION (NEW NAME)

\section{Type locality}

The type locality for the Hoko River Formation is designated as the exposures in the stream bed and cliffs of the Hoko River and in railway and road cuts parallel to the river from a point $1 \mathrm{~km}$ north of the junction of Blue Canyon with the Hoko River southward to a point $1.5 \mathrm{~km}$ north of the Hoko Falls bridge (fig. 8). The shore cliffs and wave-cut

1/U.S. Geological Survey, Menlo Park, Calif. $\underline{2}$ /Oregon State University, Corvallis, Oreg. 


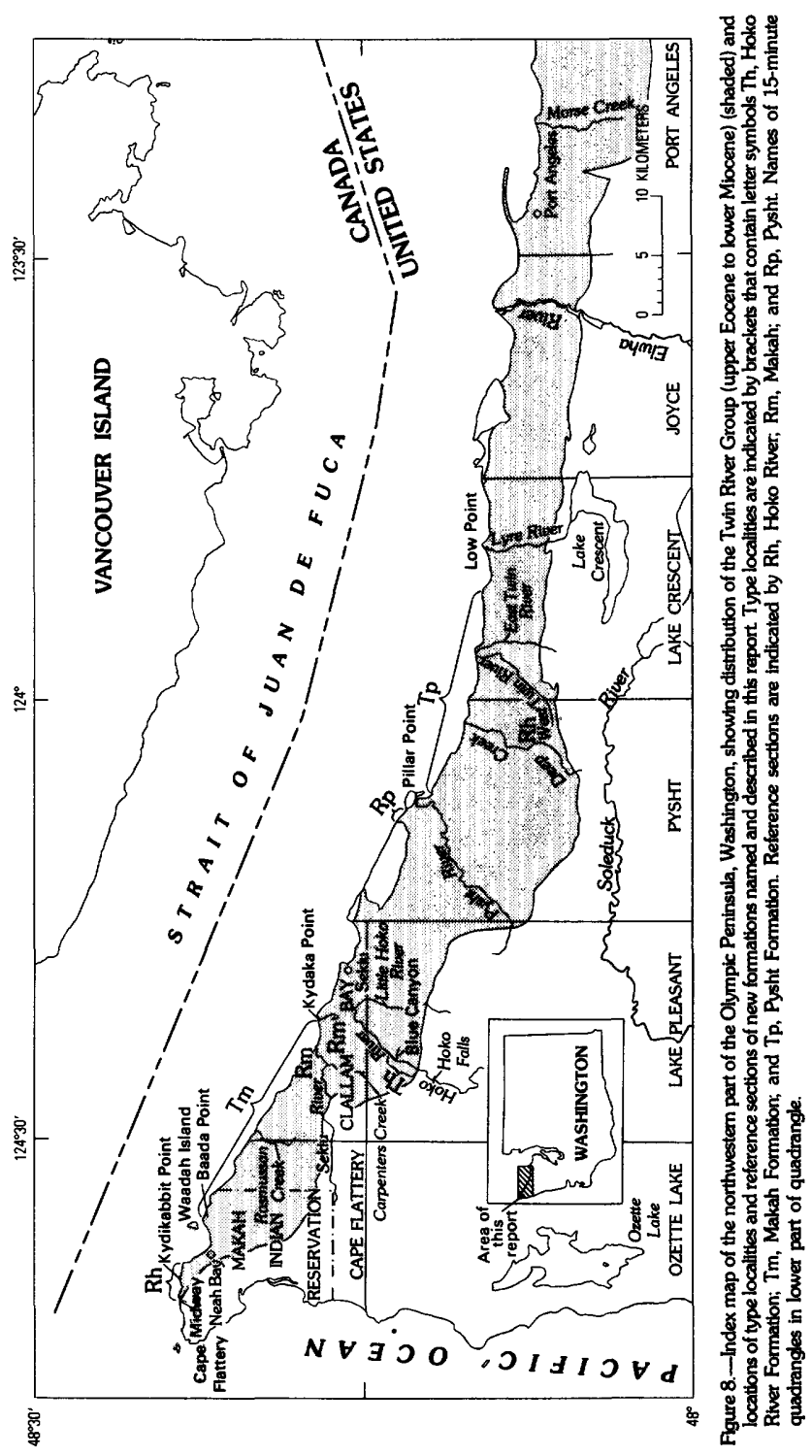




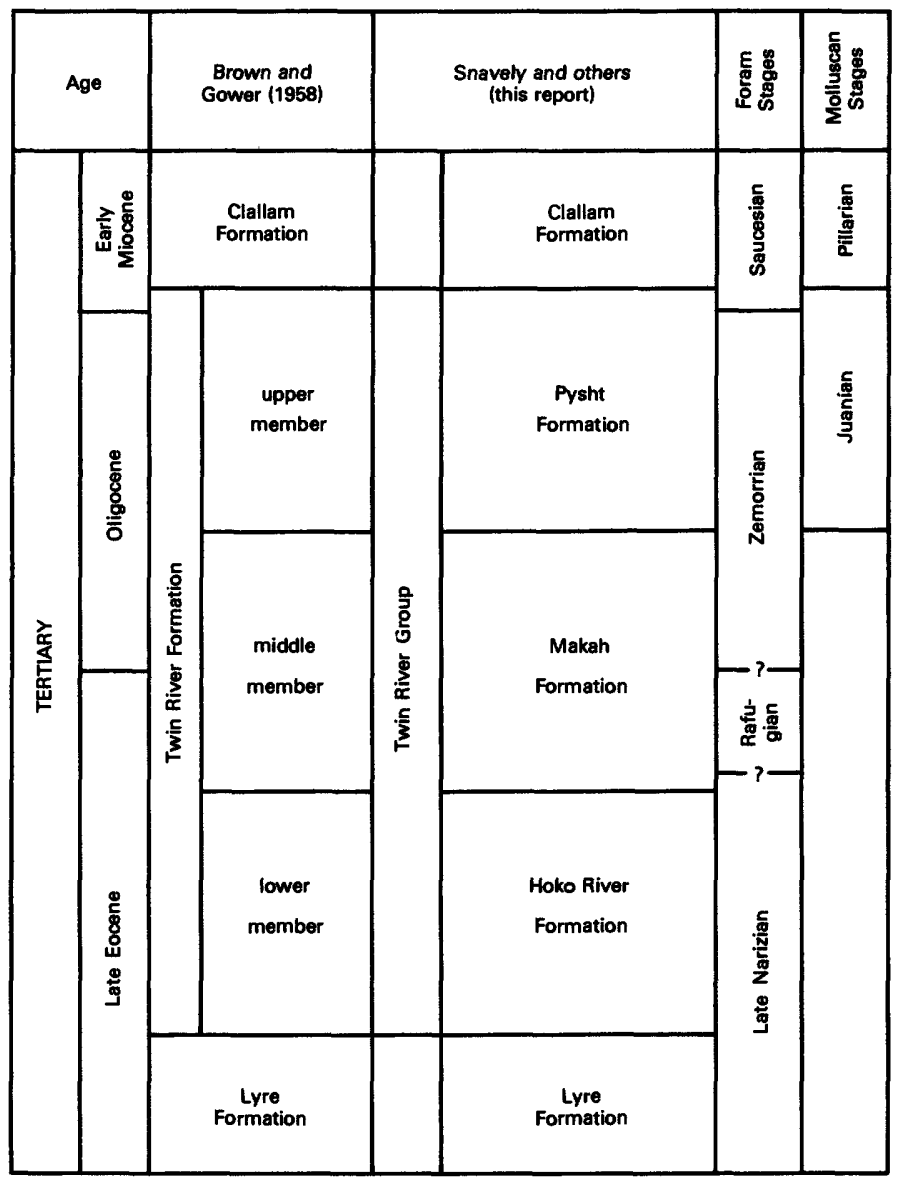

Figure 9.-Comparison between the Twin River Formation of former usage and the Twin River Group. Foraminiferal and molluscan stages assigned to the Hoko River, Makah, and Pysht Formations of the Twin River Group are based on the benthonic foraminiferal stages of Kleinpell (1938), Rau (written commun., 1978), Schenck and Kleinpell (1936), and Mallory (1959); and the Pacific Northwest Molluscan Stages of Addicott (1976a).

platform exposures along the Strait of Juan de Fuca from Midway eastward to Neah Bay are named as a reference section. The stream bed and road exposures along Deep Creek from a point $140 \mathrm{~m}$ north of the northern border of sec. 1 , T. $30 \mathrm{~N}$., R. $11 \mathrm{~W}$., south to a point $2.2 \mathrm{~km}$ east and $0.7 \mathrm{~km}$ north of the southeast corner, sec. $16, \mathrm{~T} .30 \mathrm{~N} ., \mathrm{R} .11 \mathrm{~W}$. , in Pysht quadrangle, are also designated as a reference section. 


\section{Lithologic characteristics}

The Hoko River Formation consists predominantly of massive to thin-bedded siltstone, and lesser interbeds are of thin- to thick-bedded phyllitic and basaltic sandstone, pebbly sandstone, and conglomerate (fig. 10). Channels and lenses of conglomerate and lithic sandstone as much as $2.5 \mathrm{~km}$ wide and 90 to $150 \mathrm{~m}$ thick occur locally in the sequence. Channels exposed along the cliffs between Midway and Neah Bay (fig. 8) contain clasts of basalt, phyllite, and meta-igneous rocks that range from angular to rounded and from 3 to $4.5 \mathrm{~m}$ in diameter. Pebbly mudstone beds are present in the lower part of the formation. Grading is common in the coarse and medium-grained sandstone beds.
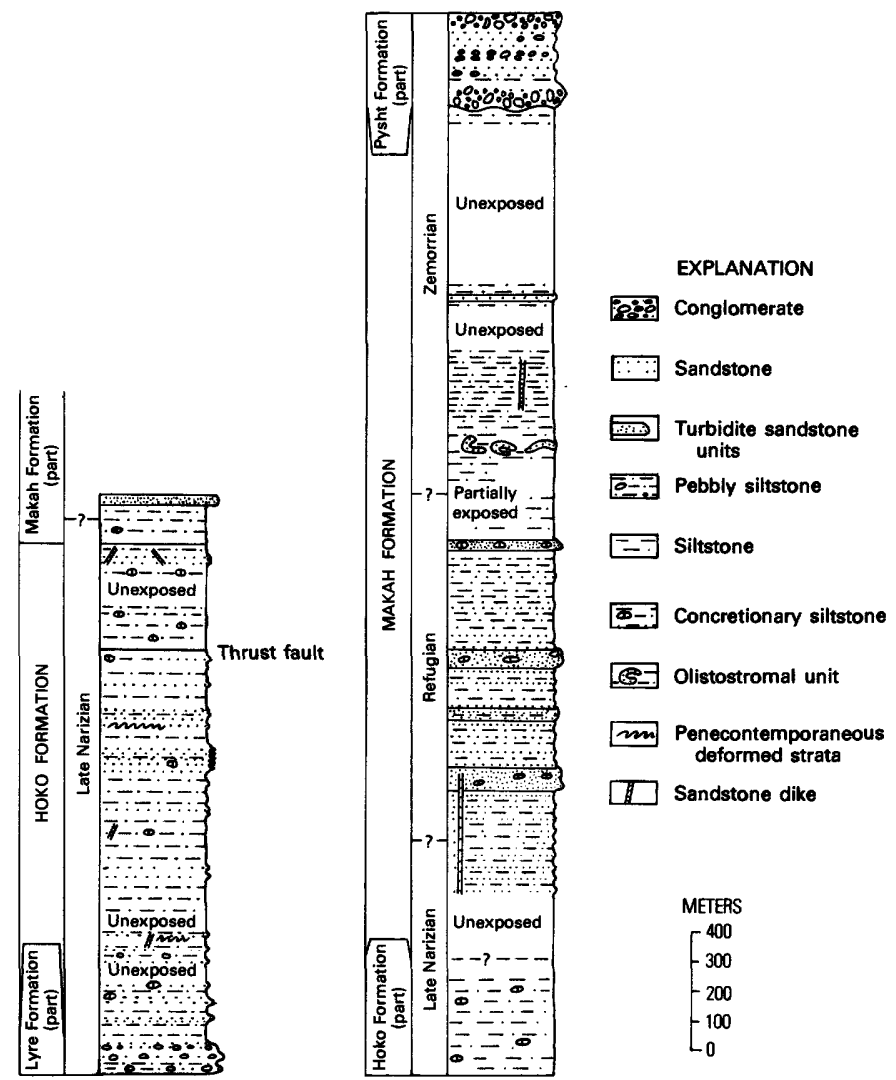

Figure 10.-Generalized stratigraphic sections and benthonic foraminiferal stages for the Hoko River and Makah Formations in thetr type localities, Clallam County, Washington. Figure 8 shows the type localities and reference sections. See Brown and Gower (1958) for stratigraphic section of Pysht Formation. 
Calcareous concretions occur throughout the Hoko River Formation and locally contain fossil crabs, gastropods, and carbonized wood; other concretions have calcite nuclei. Sandstone dikes as much as $1 \mathrm{~m}$ wide occur locally.

Silica minerals are the most abundant grain type in the sandstone and include both polycrystalline quartz and chert varieties. Feldspar is predominantly sodic plagioclase, and ratio of plagioclase to potassium feldspar is 5 to 1 . Lithic grains are predominantly phyllite, sheared sandstone, basalt, and metabasalt. Carbonaceous debris and Foraminifera are common. Calcite cement forms as much as 40 percent of some sandstone beds. Traces of laumontite and silica cement are found throughout the unit.

\section{Contact relations and thickness}

The basal siltstone beds of the Hoko River Formation conformably overlie sandstone and conglomerate of the Lyre Formation (Brown and others, 1956). Near Cape Flattery, the Hoko River Formation intertongues with the Lyre Formation, which consists of medium- to thick-bedded phyllitic sandstone, lithic conglomerate, and sedimentary breccia. The upper contact of the Hoko River Formation is exposed in only a few places in the Cape Flattery and Clallam Bay quadrangles and in most places appears to be gradational with the overlying siltstone of the Makah Formation. However, the upper part of the Hoko River Formation was eroded across a broad anticlinal arch between the Hoko River and Rasmussan Creek (fig. 8), and an unconformity is locally present in this area between the Hoko River Formation and the overlying Makah Formation.

The Hoko River Formation is approximately $1,600 \mathrm{~m}$ thick at the type locality (fig. 10) and 2,300 m thick at the reference section on Deep Creek (Brown and Gower, 1958, fig. 3).

\section{Age}

Foraminifera and mollusks indicate that the Hoko River Formation is late Eocene in age. Studies of benthonic foraminifers by Rau (1964, and written commun., 1977) places the Hoko River Formation in the late Narizian Stage of Mallory (1959). Fossil crabs from concretions in the conglomerate channel at Kydikabbit Point are late Eocene in age (Addicott, written commun., 1975). 
MAKAH FORMATION (NEW NAME)

\section{Type locality}

The Makah Formation is named after the Makah Indian Reservation in the northwesternmost part of the Olympic Peninsula, Wash. The type locality is designated as the shore cliffs and wave-cut platform exposures along the Strait of Juan de Fuca from Waadah Island and Baada Point to Kydaka Point (Fig. 8). Reference sections include exposures in the stream bed of the Hoko River, in road cuts, and in an abandoned railway that parallels the river from its mouth to the northeast corner of sec. 32, T. $32 \mathrm{~N} .$, R. 13 W., in Lake Pleasant quadrangle. A supplemental reference section is the outcrop along the Sekiu River and adjacent logging road from the river mouth to its junction with Carpenters Creek (fig. 8).

\section{Lithologic characteristics}

The Makah Formation consists predominantly of thin-bedded siltstone and sandstone separating six mappable members, which include four packets of thick-bedded amalgamated turbidite sandstones, an olistostromal unit composed of shallow-water marine sandstone and pebble conglomerate, and a thin bed of water-laid tuff (fig. 10). The members of the Makah Formation are still being studied.

The turbidite sandstone packets are thick to very thick bedded, amalgamated, and contain sequences (Bouma, 1962). The sandstone is fine to very fine grained micaceous, lithic-bearing, and quartzo-feldspathic. Amalgamated beds are generally massive and have thin, parallellaminated to convolute-laminated intervals. Calcareous concretions are found throughout the formation and range from small spheroids 60 to 150 $\mathrm{mm}$ in diameter in the siltstone to resistant zones of ellipsoidal concretions 0.5 to $4 \mathrm{~m}$ in length in the sandstone. The siltstone is medium light-gray and hackly fractured and commonly contains very fine grained sandstone stringers and carbonaceous laminae.

Sandstone dikes are present in the Makah Formation and range in width from $20 \mathrm{~mm}$ to $1 \mathrm{~m}$. Zones of penecontemporaneously deformed strata as much as several meters thick occur locally in the thin-bedded siltstone and sandstone units.

A 200-m-thick olistostromal unit occurs near the middle of the Makah Formation and consists of large blocks of fossiliferous shallowwater marine basaltic sandstone and pebble conglomerate enclosed in penecontemporaneously deformed sandstone and siltstone beds. This unit occurs within a deep-water thin-bedded sandstone and siltstone sequence typical of the Makah Formation. 
A 1-m-thick tuff unit consisting of seven thin water-laid silicified tuff beds 40 to $150 \mathrm{~mm}$ thick occurs in the lower part of the formation. This tuff member has been mapped along strike for $20 \mathrm{~km}$ in the Clallam Bay quadrangle.

\section{Contact relations and thickness}

Although the basal contact of the Makah Formation is poorly exposed in most places, the formation appears to be conformable and gradational with the underlying Hoko River Formation where the contact is exposed in the Little Hoko River and adjacent logging roads. A local unconformity occurs, however, over a broad anticline in the Hoko River Formation and older strata between the Hoko River and Rasmussan Creek (fig. 8). There, strata in the lower part of the Makah Formation lap out against the anticlinal high, but reappear east of the anticline east of the Hoko River. Makah strata above the local unconformity extend uninterrupted across the anticlinal structure.

The upper contact of the Makah Formation is placed at the base of a unit of thick-bedded sandstone and boulder and pebble conglomerate that occurs in the lower part of the predominantly massive siltstone sequence herein named the Pysht Formation. Where best exposed in road cuts 1.6 $\mathrm{km}$ southeast of Kydaka Point (fig. 8), the contact with the overlying Pysht Formation appears to be gradational. Immediately north of the airport, $0.6 \mathrm{~km}$ northwest of Sekiu, quarry faces and road cuts expose a cobble and boulder conglomerate of the Pysht Formation that is channeled into the underlying thin-bedded Makah siltstone and sandstone, suggesting a local erosional unconformity.

A thickness of $2,800 \mathrm{~m}$ is estimated for the Makah Formation at the type locality between Neah Bay and Kydaka Point (fig. 10). The thickness of the reference section along the Hoko River is $2,500 \mathrm{~m}$. Approximately 700 to $800 \mathrm{~m}$ of basal Makah strata are missing across the broad anticlinal high between the Hoko River and Rasmussan Creek (fig. 8).

\section{Age}

As shown in figure 9, foraminiferal assemblages studied by Rau (written commun., 1978) indicate that the Makah Formation ranges in age from late Eocene (late Narizian Stage of Mallory, 1959), to Oligocene (Zemorrian Stage of Schenck and Kleinpe11, 1936). Mollusks from sandstone blocks in the olistostromal unit are late Eocene in age (Lincoln Stage of Weaver, 1937) and Foraminifera from siltstone in this unit are also late Eocene (Refugian Stage of Schenck and Kleinpe11, 1936). This deformed unit is overlain by thin-bedded strata of Zemorrian Age, indicating that these shallow-water upper Eocene olistostromal deposits were transported into the deep marginal basin by a large submarine slide during olígocene time. 
PYSHT FORMATION (NEW NAME)

\section{Type 1ocality}

The type locality (fig. 8) is designated as the shore-cliff exposures along $18 \mathrm{~km}$ of the Strait of Juan de Fuca from Pillar Point State Park (near center sec. 10, T. $31 \mathrm{~N} .$, R. $11 \mathrm{~W}$. , Pysht quadrangle) eastward to a point $3.5 \mathrm{~km}$ west of Low Point (SW cor., sec. 19, T. 31 N., R. 9 W., Lake Crescent quadrangle). Exposures in the cliffs and on the wave-cut platform 1.9 to $2.7 \mathrm{~km}$ west of Pillar Point are designated as a reference section.

\section{Lithologic characteristics}

The Pysht Formation is composed chief 1 y of massive medium-gray to light olive-gray mudstone and sandy siltstone. The argillaceous rocks are poorly indurated and contain calcareous concretions 25 to $100 \mathrm{~mm}$ in diameter. A few 1ight-gray 5-mm-to $0.5-\mathrm{m}-$ thick subfeldspathic sandstone beds occur in the sequence (Brown and Gower, 1958, fig. 3).

Channel deposits of pebble and boulder conglomerate containing interbedded lithic and quartzo-feldspathic sandstone and mudstone occur at the base of the Pysht Formation along the coast between Sekiu and Kydaka Point in the eastern part of the Clallam Bay quadrangle. However, similar conglomerate and sandstone channels in the western part of the Pysht quadrangle were mistakenly included in the Clallam Formation (1ower Miocene) by Gower (1960), but were later included within the upper member of the Twin River Formation (Pysht equivalent) by Addicott (1976a, b).

These conglomerate lenses consist of cobble- to boulder-sized subrounded to rounded clasts of metamorphic and igneous rocks and mollusk-bearing fine-grained sandstone. Light-gray cobbles of a distinctive felsic tuff also occur in these conglomerate members.

The lithologic similarities between the conglomerate and sandstone lenses in the Sekiu-Kydaka Point area and those in the Pysht quadrangle suggest that they occur in the same stratigraphic position and mark the basal contact of the Pysht Formation.

The upper 30 to $40 \mathrm{~m}$ of the formation consists of alternating mudstone and light-gray lithic sandstone. 


\section{Contact relations and thickness}

The Pysht Formation overlies the Makah Formation with a gradational contact. This contact is exposed in several road cuts between Sekiu and Kydaka Point where thin-bedded siltstone and sandstone of the Makah Formation interbeds upward with conglomerate in the lower part of the Pysht Formation. The lower contact of the Pysht Formation is exposed farther east in Deep Creek and in the Lyre River where Brown and Gower (1958) indicated that it is conformable and gradational with their underlying middle member (Makah equivalent).

The upper contact of the Pysht Formation is well exposed in the shore cliffs and wave-cut platform $2.5 \mathrm{~km}$ west of Pillar Point (Gower, 1960; Addicott, 1976a, b). Here, a gradational and conformable contact separates the sandy siltstone and mudstone of the Pysht Formation from the overlying thick-bedded sandstone of the Clallam Formation (Addicott, 1976a, fig. 8; Gower, 1960).

The Pysht Formation is estimated to be $1,100 \mathrm{~m}$ thick along the Pysht River, but structural complications in this area make an accurate thickness measurement tenuous. Farther east, strata assigned to the Pysht are estimated to be $1,400 \mathrm{~m}$ thick (Brown and Gower, 1958).

\section{Age}

Foraminifera and mollusks indicate that the Pysht Formation is late 0ligocene in age (fig. 10). A study of benthonic foraminifers by Rau (1964; written commun., 1977) would place he Pysht Formation in the Zemorrian Stage (Kleinpe11, 1938). The boundary between the Zemorrian and Saucesian Stages is in the uppermost part of the Pysht on the basis of the benthonic foraminifers (Addicott, 1967b, p. 442).

Durham (1944) assigned mollusks collected from the Pysht Formation along the Strait of Juan de Fuca to his Echinophoria apta zone of the late Oligocene.

Reworked sandstone boulders in the conglomerate channels in the Pysht and Clallam quadrangles contain a large number of mollusks. Addicott (1976a; written commun., 1973) stated that these fossils represent a very shallow water depositional environment and are probably coeval with fauna of the Echinophoria apta zone of Durham (1944), which Addicott included in his late 01igocene or early Miocene Juanian Stage of the mega-invertebrate sequence (Addicott, 1976a; and fig. 9). Foraminifers indicative of the late Oligocene Zemorrian Stage occur in siltstone interbeds in the basal conglomerate near Sekiu. Addicott (1976a) considered the latest Zemorrian to be ear1y Miocene in age. Sedimentary structures indicate that the reworked fossiliferous sandstone boulders in the conglomerate channels in the Pysht Formation were derived from nearly coeval but lithified neritic deposits on an ancient Vancouver shelf and were transported into the deep basin through large submarine channels. 


\section{Summary}

The three informal members previously assigned to the Twin River Formation by Brown and Gower (1958) are now assigned, in ascending

order, to the Hoko River Formation, the Makah Formation, and the Pysht Formation (fig. 9). The Twin River Formation is herein raised in rank to the Twin River Group. Investigations are still in progress concerning members of the Hoko River and Makah Formations.

AGE AND CONTINUITY OF THE VALDEZ GROUP, SOUTHERN ALASKA

By Russel1 G. Tysdal ${ }^{1}$ and George Plafker ${ }^{2}$

The name Valdez Group (originally named Valdes series) was given to rocks near Port Valdez (fig. 11) by Schrader $(1899,1900)$, and subsequent1y was used by Moffit (1954) for rocks exposed in the northwestern part of Prince William Sound that previously were called the Sunrise series by Mendenhal1 (1899, 1900). Similar strata north and south of Turnagain Arm were mapped as Valdez(?) Group by Clark (1972), however, because continuity with Valdez of the type area was not established. This pape $r$ sumarizes evidence establishing the continuity of the strata, permitting removal of the query from the Valdez(?) Group. Fauna collected from the Valdez Group (as used here) were, until the studies of Jones (Jones and Clark, 1973), assigned a Jurassic to Cretaceous age. Jones' work showed that all age-diagnostic fossils of the Valdez identified to species level are Maestrichtian and Campanian(?) (latest Cretaceous). Thus, we consider the Valdez to be of Late Cretaceous age and abandon the Jurassic to Cretaceous age assignment.

$1 /$ U.S. Geological Survey, Reston, Va. 2//Geological Survey, Menlo Park, Calif. 


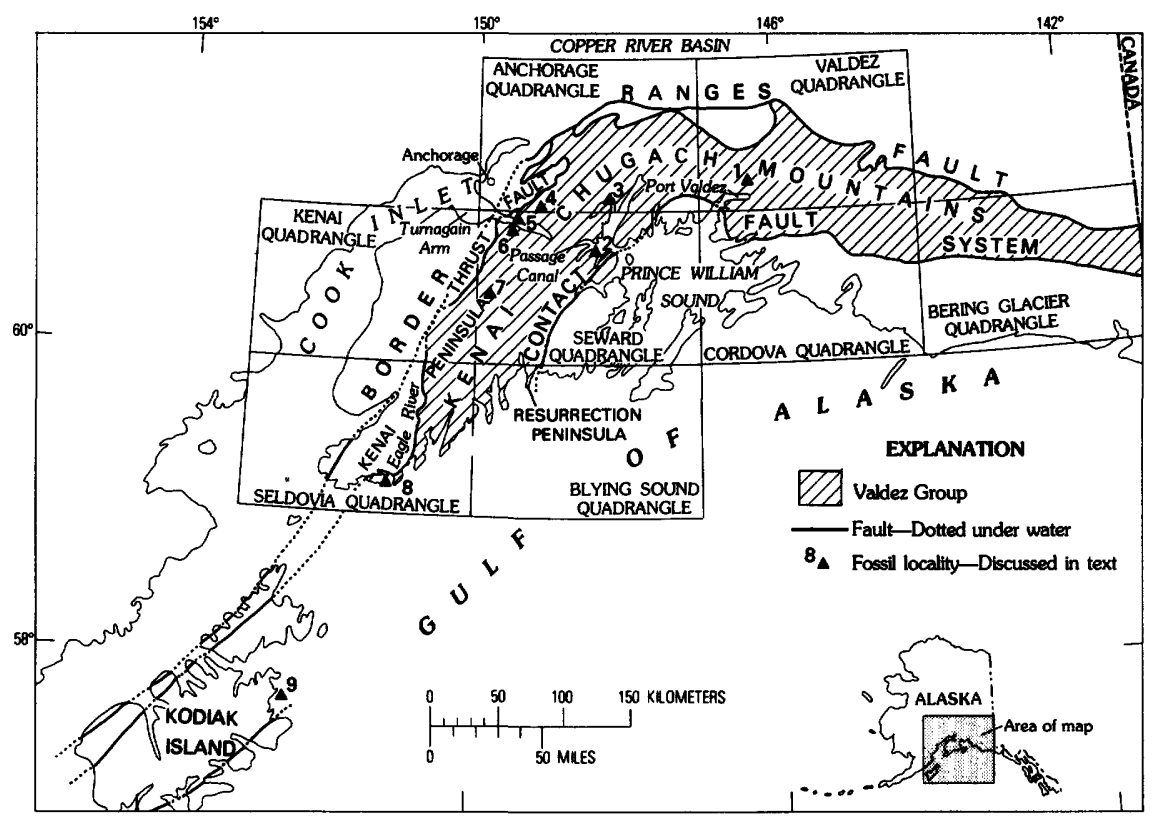

Figure 11.-Map showing area of Valdez Group.

VALDEZ GROUP

The Valdez Group is a thick sequence of rhythmically interbedded, indurated graywacke, siltstone, and minor mudstone and pebble conglomerate. Graded beds, cross beds, convolute laminations, and flame structures are present but are not readily observed owing to deformation and metamorphism. Valdez strata locally contain interbedded tuff and pillow basalt and on the Resurrection Peninsula are intruded by basalt sills and sheeted dikes, gabbro, and rarely serpentinized dunite (Tysdal and others, 1977; Tysdal and Case, in press). The entire sequence is intensely folded and regionally metamorphosed to grades ranging from the zeolite facies and the lowermost greenschist facies to the upper zones of the amphibolite facies. Granitic plutons and dikes intrude the Valdez in some areas.

Rocks exposed in the Port Valdez area and northward across the Chugach Mountains to the Copper River Basin originally were named "Valdes series" by Schrader $(1899,1900)$. Port Valdez (formerly spelled 
Va1des) is the type area, but no type section was designated. In the same publications, the name Sunrise series was introduced by Mendenhal1 (1899, 1900) for rocks exposed along Passage Canal (then called Portage Bay) "al1 about the western waters of Prince William Sound," a1ong the overland route from Resurrection Bay (west of Resurrection Peninsula, fig. 11) to Turnagain Arm, and along the shore of the Arm. Grant and Higgins (1910) changed the name of the Valdez to Valdez Group and, 1ike Mendenha11, assigned most of the strata along the eastern side of the Kenai Peninsula, south from Resurrection Bay, to the Sunrise series. Moffit (1954) believed that part of the Sunrise strata in the northwestern part of the Prince William Sound was westward continuation of the Valdez Group, and he abandoned usage of the name Sunrise series.

Strata north of Turnagain Arm were designated as Valdez(?) Group by Clark (1972) because correlation with rocks of the type area was not certain. The query is herein removed from the Valdez(?) Group because continuity has been established between rocks of the type area and those of the Turnagain Arm area. Plafker, Hudson, and Winkler (unpub. data, 1975) have traced Valdez strata from the type area at Port Valdez across the southeastern corner of the Anchorage quadrangle and into the Seward quadrangle. Tysdal and Case (in press; unpub. data, 1976) have shown continuity of Valdez rocks in the Seward quadrangle with those of the Anchorage quadrangle, including the Turnagain Arm a rea.

From its type area, the Valdez Group was traced eastward across the Valdez, Cordova, and Bering Glacier quadrangles to the Canadian border (Plafker, Hudson, and Winkler, unpub. data, 1975) and southward through the Seward, Blying Sound, Kenai, and Seldovia quadrangles to the southern part of the Kenai Peninsula (Tysda1 and Case, unpub. data 1976; Plafker, unpub. data, 1975). The southern limit of the Valdez Group is defined by the Contact fault system, a major structure that extends westward from near the Canadian border in the Chugach Mountains to Prince William Sound (Winkler and Plafker, 1975); thence, southward through the Seward quadrangle and into the Blying Sound quadrangle (Tysdal and Case, in press). Plafker and others (1977) project it southwestward to Kodiak Island, where it juxtaposes correlative Cretaceous rocks on the northwest against Tertiary rocks. The northern margin of the Valdez Group is delimited by the Border Ranges fault system, a major system of faults that extends from the Kodiak Islands into Canada and probably into southeastern Alaska (MacKevett and Plafker, 1974; Plafker and others, 1977), or by the Eagle River thrust fault and related faults (Clark, 1972; Plafker and others, 1977; Tysdal and Case, 1977, in press). 


\section{Age}

We consider the Valdez Group to be Late Cretaceous in age because all of the age-diagnostic fossils identified to species level are of Maestrichtian and possibly Campanian (latest Cretaceous) Age. The unit previously was assigned a Jurassic to Cretaceous age because of uncertainty regarding (1) the age range of the few fossils then known and (2) boundaries of the Valdez Group in its eastern extensions and its possible correlation with units containing Late Jurassic fossils (Plafker and MacNe11, 1966). New mapping precludes the possibility that Jurassic strata are included within the group (P1afker and Hudson, unpub. data, 1977).

Prior to the studies of Jones (Jones and Clark, 1973), all the agediagnostic fossils obtained from the Valdez Group (as defined here) were assigned to the range of Jurassic to Cretaceous. Ulrich (1910) considered Inoceramya concentrica, collected from strata on Woody Island (loc. 9, fig. 11) that are correlative with the Valdez Group, as Early Jurassic (Jones and Clark, 1973). Inoceramus fossils collected north of Turnagain Arm (loc. 4, fig. 11) by B. L. Johnson in 1911 were believed by $\mathrm{T}$. W. Stanton to be similar to Inoceramya concentrica, but he stated that there was no essential difference in general type between the Jurassic species of Inoceramus and some of those in the Cretaceous (Martin and others, 1915). Johnson also collected Inoceramus from float on a moraine on the east side of Valdez Glacier (loc. 1, fig. 11) and Inoceramya concentrica from the north side of Barry Arm (loc. 3, fig. 11) and from float at Point Cochrane (loc. 2, fig. 11) (Johnson, 1914). Park (1933) collected imprints of Inoceramus from six closely spaced localities (loc. 4, fig. 11) north of Turnagain Arm that J. B. Reeside, $\mathrm{Jr}$., believed were Cretaceous, largely because he thought it unlikely that so many Inoceramus would be present in a rock older than Cretaceous. D. L. Jones (in Plafker and MacNeil, 1966) restudied these collections and concluded that the fossils, which are mostly poorly preserved, could not be assigned a more definite age than Jurassic to Cretaceous. But subsequent collections of fossils from the Valdez Group of the Kenai-Chugach Mountains and from correlative rocks on Woody Island (loc. 9, fig. 11) have yielded Inoceramus kusiroensis, a widespread fossil of Maestrichtian Age; it occurs with Inoceramya concentrica at some localities (Jones and Clark, 1973). In addition, poorly preserved Inoceramus collected by Plafker and John Kelley from the Valdez Group near Point Dick (loc. 8, fig. 11) are, according to Jones (oral commun., 1977), of Campanian or Maestrichtian Age. No other age-diagnostic species have been collected from the Valdez Group. 
The fossil localities north and south of Turnagain Arm (1oc. 4, 5, 6, 7, fig. 11), at Barry Arm and Point Cochrane, and at Valdez Glacier show that these Maestrichtian fossils span almost $3 / 4$ of the width of outcrops of the Valdez Group. Tysdal and Case (1977) suggested that those localities north and south of Turnagain Arm may be in the central part of a complex synclinorium, and we suspect that the Barry Arm-Point Cochrane trend also may be synclinal. The intervening areas could represent somewhat older rocks, but no data exist to suggest that the rocks are older than Late Cretaceous. Certainly no evidence exists to indicate a Jurassic age.

Acker, C. J., 1958, Geologic interpretations of a siliceous breccia in the Colossal Cave area, Pima County, Arizona [abs.]: Arizona Geol. Soc. Digest, p. 47.

Addicott, W. 0., 1972, Provincial middle and late Tertiary molluscan stages, Temblor Range, California, in The Pacific Coast Miocene Biostratigraphy Symposium, 47th, Bakersfield, Calif., March 9-10 1972, Proc.: Soc. Econ. Paleontologists and Mineralogists, Pacific Sec. p. 1-26.

, 1976a, Molluscan paleontology of the lower Miocene Clallam Formation, northwestern Washington: U.S. Geol. Survey Prof. Paper 976, $44 \mathrm{p}$.

, $1976 \mathrm{~b}$, New molluscan assemblages from the upper member of the Twin River Formation, western Washington: significance in Neogene chronostratigraphy: U.S. Geol. Survey Jour. Research, v. 4, no. 4, p. 437-447.

Allen, R. M., Jr., 1963, Geology and mineral resources of Green and Madison Counties: Virginia Div. Mineral Resources Bu11. 78, $102 \mathrm{p}$.

American Commission on Stratigraphic Nomenclature, 1952, Report 2-Nature, usage, and nomenclature of time stratigraphic and geologic-time units: Am. Assoc. Petroleum Geologists Bu1l., v. 36 , no. 8 , p. 1627-1638. , 1970, Code of stratigraphic nomenclature: Tulsa, 0kla., Am. Assoc. Petroleum Geologists, 21 p. 
Armstrong, A. K., 1962, Stratrigraphy and paleontology of the Mississippian System in southwestern New Mexico and adjacent southeastern Arizona: New Mexico Bur. Mines and Mineral Resources Mem. 8, 95 p.

1970, Mississippian stratigraphy and geology of the northwestern part of the Klondike Hills, southwestern New Mexico in Guidebook of the Tyrone-Big Hatchet Mountains-Florida Mountains region--New Mexico Geol. Soc. Field Conf. 21st, 1970: New Mexico Bur. Mines and Mineral Resources, p. 59-63.

Armstrong, A. K., and Mamet, B. L., 1978, Carboniferous microfacies, microfossils, and corals, Lisburne Group, Arctic Alaska: U.S. Geo1. Survey Prof. Paper 849, 144 p.

Arnold, Ralph, and Hanniba1, Harold, 1913, The marine Tertiary stratigraphy of the north Pacific Coast of America: Am. Philos. Soc. Proc., v. 52, no. 212, p. 559-605.

Berggren, W. A., 1969 , Cenozoic chronostratigraphy, planktonic foraminiferal zonation and the radiometric time scale: Nature, v. 224, no. 5224, p. 1072-1075.

1972, A Cenozolc time-scale--Some implications for regional geology and paleobiogeography: Lethaia, v. 5, no. 2, p. 195-215.

Blake, W. P., 1908, Note upon the structure of the Santa Catalina gneiss, Arizona: Science, n.s. v. 28, p. 378-380, 382 .

Bloomer, R. 0., and Werner, H. J., 1955, Geology of the Blue Ridge region in central Virginia: Geol. Soc. America Bull., v. 66, no. 5, p. 579-606.

Bouma, A. H., 1962, Sedimentology of some flysh deposits: Amsterdam, New York, Elsevier Publishing Co., 168 p.

Brabb, E. E., 1960, Geology of the Big Basin area, Santa Cruz Mountains, California: Dissert. Abs., v. 21, no. 5, p. 1163.

1964, Subdivision of San Lorenzo Formation (Eocene-Oligocene), west-central California: Am. Assoc. Petroleum Geologists Bull., v. 48, no. 5, p. 670-679.

Brosgé, W. P., Dutro, J. T., Jr., Mangus, M. D., and Re1ser, H. N., 1962, Paleozolc sequênce in eastern Brooks Range, Alaska: Am. Assoc. Petroleum Geologists Bull., v. 46, no. 12, p. 2174-2198.

Brown, R. D., Jr., and Gower, H. D., 1958, Twin River Formation (redefinition), northern Olympic Peninsula, Washington: Am. Assoc. Petroleum Geologists Bull., v. 42, no. 10, p. 2492-2512.

Brown, R. D., Jr., Gower, H. D., and Snavely, P. D., Jr., 1960, Geology of the Port Angeles-Lake Crescent area, Clallam County, Washington: U.S. Geol. Survey Oil and Gas Inv. Map OM-203.

Brown, R. D., Jr., Snavely, P. D., Jr., and Gower, H. D., 1956, Lyre Formation (redefinition), northern olympic Peninsula, Washington: Am. Assoc. Petroleum Geologists Bu11., v. 40, no. 1, p. 94-107.

Campbe11, L. D., 1969, Stratigraphy and paleontology of the Kinzers Formation, southeastern Pennsylvania: Lancaster, Pa., Franklin and Marshall College, unpub. M. S. thesis.

1971, Occurrence of "Ogygopsis shale" fauna in southeastern Pennsylvania: Jour. Pale ontology, v. 45, no. 3, p. 437-440. 
Carlisle, Donald, and others, 1957, Devonian stratigraphy of Sulphur Springs and Pinyon Ranges, Nevada: Am. Assoc. Petroleum Geologists Bu11., v. 41, no. 10, p. 2175-2191.

Clark, S. H. B., 1972, Reconnaissance bedrock geologic map of the Chugach Mountains near Anchorage, Alaska: U. S. Geol. Survey Misc. Field Studies Map MF-350.

Clark, W. Z., Jr., and Zisa, A. C., 1976, Physiographic map of Georgia: Georgia Dept. Nat. Resources, Geologic and Water Resources Div.

Cohee, G. V., and Wright, W. B., 1972, Changes in stratigraphic nomenclature by the U.S. Geological Survey, 1971: U.S. Geol. Survey Bull. 1372-A, 28 p.

Conlin, R. R., and Hoskins, D. M., 1962, Geology and mineral resources of the Mifflintown quadrangle, Pennsylvania:

Pennsylvania Geol. Survey, 4th ser., Topog. and Geol. Atlas A-126, $46 \mathrm{p}$.

Crawford, T. J., and Medlin, J.H., 1974, Brevard fault zone in western Georgia and eastern Alabama: Georgia Dept. Natural Resources, Earth and Water Div., Guidebook 12, p. 1-67.

Davis, F. L., 1937, The geological field excursion of 1935 of the Oregon State College, Department of Geology: Geol. Soc. Oregon County News Letter, v. 3, no. 2, p. 11-19.

Dickinson, W. R., and Vigrass, L. W., 1965, Geology of the Suplee-Izee area, Crook, Grant, and Harney Counties, Oregon: Oregon Dept. Geology and Mineral Resources Bu11. 58, 109 p.

Durham, D. L., 1973, Geology of the southern Salinas Valley area, California: U.S. Geo1. Survey Prof. Paper 819, 111 p.

Durham, D. L., and Addicott, W. 0., 1964, Upper Miocene and Pliocene marine stratigraphy in southern Salinas Valley, California:

U.S. Geol. Survey Bull. 1194-E, 7 p.

, 1965, Pancho Rico Formation, Salinas Valley, California: U.S. Geol. Survey Prof. Paper 524-A, 22 p.

Durham, J. W., 1944, Megafaunal zones of the Oligocene of northwestern Washington: California Univ., Dept. Geol. Sc1. Bul1., v. 27, no. 5, p. 101-211.

Dutro, J. T., Jr., Brosgé, W. P., and Reiser, H. N., 1972, Significance of recently discovered Cambrian fossils and reinterpretation of the Neruokpuk Formation, northeastern Alaska: Am. Assoc. Petroleum Geologists Bu11., v. 56, no. 4, p. 808-815.

Dyson, J. L., 1967, Geology and mineral resources of the southern half of the New Bloomfield quadrangle, Pennsylvania: Pennsylvania Geol. Survey Atlas A-137cd, 86 p.

Englund, K. J., 1961, Regional relation of the Lee Formation to overlying formations in southeastern Kentucky and adjacent areas of Tennessee [abs.]: Geol. Soc. America Spec. Paper 68, p. 69-70.

Englund, K. J., Arndt, H. H., Gillespie, W. H., Henry, T. W., and Pfefferkorn, H. W., 1977, A field guide to proposed Pennsylvanian System stratotype, West Virginia: Am. Assoc. Petroleum Geologists/Soc. Econ. Paleontologists and Mineralogists, Ann. Convention, Washington, D. C., June 1977 [Guidebook], 80 p. 
Evernden, J. F., Savage, D. E., Curtis, G. H., and James, G. T., 1964, Potassium-argon dates and the Cenozoic mammalian chronology of North America: Am. Jour. Sci., v. 262, p. 145-198.

Faill, R. T., Wells, R. B., and Sevon, W. D., 1977, Geology and mineral resources of the Salladasburg and Cogan Station quadrangles, Lycoming County, Pennsylvania: Pennsylvania Geol. Survey, 4th ser., Atlas A-133cd.

Geological Society of London, 1964, Summary of the Phanerozoic time scale--the Geological Soclety Phanerozoic time-scale, 1964, in Harland, W. B., Smith, A. G., and Wilcock, Bruce, eds., The Phanerozoic time scale--a symposium: Geo1. Soc. London Quart. Jour., v. 120s, p. 260-262.

Gohn, G. S., 1976, Sedimentology, stratigraphy, and paleogeography of lower Paleozoic carbonate rocks, Conestoga Valley, southeastern Pennsylvania: Univ. Delaware, unpub. Ph.D. dissert., 315 p.

Gower, H. D., 1960, Geologic map of the Pysht quadrangle, Washington: U.S. Geol. Survey Geol. Quad. Map GQ-129.

Grant, U. S., and Higgins, D. F., 1910, Preliminary report on the mineral resources of the southern part of Kenai Peninsula: U.S. Geol. Survey Bull. 442, p. 166-178.

Hatcher, R. D., 1971, Geology of Rabun and Habersham Countles, Georgia: a reconnaissance study: Georgia Geo1. Survey Bull. 83, 48 p. , 1974, An introduction to the Blue Ridge tectonic history of northeast Georgia: Georgia Dept. Nat. Resources, Earth and Water Div., Guidebook 13-A, 60 p.

Higgins, M. W., 1965, The geology of part of the Sandy Springs quadrangle, Georgia: Atlanta, Ga., Emory Univ., unpub. Masters thesis, $141 \mathrm{p}$.

, 1966, The geology of the Brevard lineament near Atlanta, Georgia: Georgia Geol. Survey Bull. 77, 49 p.

, 1968, Geologic map of the Brevard fault zone near Atlanta, Georgia: U. S. Geol. Survey Geol. Inv. Map I-511.

, 1971, Cataclastic rocks: U.S. Geol. Survey Prof. Paper 687, $97 \mathrm{p}$.

James, H. L., 1978, Subdivision of the Precambrian--A brief review and a report on a recent decision by the Subcommission on Precambrian Stratigraphy: Precambrian Research, v. 7, p. 193-204.

Jillson, W. R., 1919, The Kendrick shale; a new calcareous fossil horizon in the coal measures of eastern Kentucky: Kentucky Dept. Geology and Forestry, Ser. 5, Mineral and Forest Resources of Kentucky, v. 1, no. 2, p. 96-104.

Johnson, B. L., 1914, The Port Wells gold-lode district [Alaska]: U.S. Geol. Survey Bull. 592, p. 195-236.

Johnson, J. G., 1962, Lower Devonian-Middle Devonian boundary in central Nevada: Am. Assoc. Petroleum Geologists Bull., v. 46, no. 4, p. 542-546.

, 1965, Lower Devonian stratigraphy and correlation, northern Simpson Park Range, Nevada: Canadian Petroleum Geologists Bull., v. 13 , no. 3, p. 365-381. 
Jonas, A. I., 1928, Geologic map of Virginia: Virginia Geol. Survey prelim. ed.

Jonas, A. I., and Stose, G. W., 1926, Geology and mineral resources of the New Holland quadrangle, Pennsylvania: Pennsylvania Geol. Survey, 4th ser., Topog. and Geol. Atlas of Pennsylvania 178, 40 p. , 1930, Geology and mineral resources of the Lancaster quadrangle, Pennsylvania: Pennsylvania Geol. Survey, 4th ser., Topog. and Geol. Atlas of Pennsylvania 168, 106 p.

Jones, D. L. and Clark, S. H. B., 1973, Upper Cretaceous (Maestrichtian) fossils from the Kenai-Chugach Mountains, Kodiak and Shumagin Islands, southern Alaska: U.S. Geol. Survey Jour. Research, v. 1, no. 2 p. $125-136$.

Kleinpel1, R. M., 1938, Miocene stratigraphy of California: Tulsa, Okla., Am. Assoc. Petroleum Geologists, 450 p.

Leffingwel1, E. de K., 1919, The Canning River region, northern Alaska: U.S. Geo1. Survey Prof. Paper 109, 251 p.

Lupher, R. L., 1941, Jurassic stratigraphy of central Oregon: Geol. Soc. America Bul1., v. 52, no. 2, p. 219-270.

Mackevett, E. M., Jr., and Plafker, George, 1974, The Border Ranges fault in south-central Alaska: U.S. Geol. Survey Jour. Research, v. 2, no. 3, p. 323-329.

Mallory, V. S., 1959, Lower Tertiary biostratigraphy of the California Coast Ranges: Tulsa, Okla., Am. Assoc. Petroleum Geologists, $416 \mathrm{p}$.

Martin, G. C. Johnson, B. L., and Grant, U. S., 1915, Geology and mineral resources of Kena1 Peninsula, Alaska: U.S. Geol. Survey Bu11. 587, $243 \mathrm{p}$.

McConnel1, K. I., and Abrams, C. E., in press, Structural and 11 thologic control of Sweetwater Creek in western Georg1a: Georg1a Dept. Nat. Resources, Geol. and Water Resources Div. Bull.

McMannis, W. J., 1955, Geology of the Bridger Range, Montana: Geol. Soc. America Bull., v. 66, no. 11, p. 1385-1430.

Meisler, Harold, and Becher, A. E., 1968, Carbonate rocks of Cambrian and Ordovician age in the Lancaster quadrangle, Pennsylvania:

U.S. Geol. Survey Bull. 1254-G, 14 p.

, 1971, Hydrogeology of the carbonate rocks of the Lancaster 15-minute quadrangle, southeastern Pennsylvania: Pennsylvania Geol. Survey Water Resources Report 26, 149 p.

Mendenhal1, W. C., 1899, Report on the region between Resurrection Bay and the Tanana River, in Maps and descriptions of routes of exploration in Alaska in 1898, with general information concerning the territory: U. S. Geol. Survey Spec. Pub., p. 40-50. , 1900, A reconnaissance from Resurrection Bay to the Tanana River, Alaska in 1898: U.S. Geol. Survey 20th Ann. Rept., pt. 7 , p. 265-340. 
Moffit, F. H., 1954, Geology of the Prince William Sound region, Alaska: U.S. Geol. Survey Bul1. 989-E, p. 225-310.

Mu11, C. G., and Mangus, M. D., 1972, Itkilyariak Formation: new Mississippian formation of Endicott Group, Arctic slope of Alaska: Am. Assoc. Petroleum Geologists Bull., v. 56, no. 8, p. 1364-1369.

Murphy, M. A., and Gronberg, E. C., 1970, Stratigraphy and correlation of the Nevada Group (Devonian) north and west of Eureka, Nevada: Geo1. Soc. America Bu11., v. 81, no. 1, p. 127-136.

Murray, J. B., 1973, Geologic map of Forsyth and north Fulton Counties: Georgia Dept. Nat. Resources, Earth and Water Div.

No1f, Bruce, and Nolf, Penny, 1969, Santa Cruz Island Volcanics, in Weaver, D. W., and others, eds., Geology of the Northern Channel Islands [California]: Am. Assoc. Petroleum Geologists/Soc. Econ. Paleontologists and Mineralogists, Pacific Secs., Spec. Pub., p. 91-94.

Nomland, J. 0., 1917, The Etchegoin Pliocene of middle California: California Univ., Dept. Geology Bu11., v. 10, no. 14, p. 191-254.

Owen, D. D., 1859, Report of a geological reconnaissance of the State of Indiana made in the year 1837, Part first: Indianapolis, $63 \mathrm{p}$.

Park, C. F., Jr., 1933, The Girdwood district, Alaska: U.S. Geol. Survey Bull. 849-G, p. 381-424.

Plafker, George, and MacNeil, F. S., 1966, Stratigraphic significance of Tertiary fossils from the Orca Group in the Prince William Sound region, Alaska, in Geological Survey research 1966: U.S. Geol. Survey Prof. Paper 550-B, p. B62-B68.

Plafker, George, Jones, D. L., and Pessagno, E. A., Jr., 1977, A Cretaceous accretionary flysch and melange terrane along the Gulf of Alaska margin, in Blean, K. M., ed., The United States Geological Survey in Alaska: Accomplishments during 1976: U.S. Geol. Survey Circ. 751-B, p. B41-B43.

P1 ummer, F. B., 1933, The geology of Texas, part 3, Cenozolc systems in Texas: Texas Univ. Bul1. 3232, p. 519-818.

Puri, H. S., 1953, Contributions to the study of the Miocene of the Florida panhandle: Florida Geol. Survey Bull. 36, $345 \mathrm{p}$.

Puri, H. S., and Vernon, R. 0., 1964, Summary of the geology of Florida and a guidebook to the classic exposures: Florida Geol. Survey Spec. Pub. 5, 312 p.

Rand, W. W., 1931, Preliminary report of the geology of Santa Cruz Island, Santa Barbara County, California, in Minning in California: California State Mineralogist Rept., v. 27, no. 2, p. 214-219.

Ransome, F. L., 1904, The geology and ore deposits of the Bisbee quadrangle, Arizona: U.S. Geol. Survey Prof. Paper 21, 168 p.

Rau, W. W., 1964, Foraminifera from the northern 0lympic Peninsula, Washington: U.S. Geol. Survey Prof. Paper 374-G, 33 p.

Reed, B. L., 1968, Geology of the Lake Peters area, northeastern Brooks Range, Alaska: U.S. Geol. Survey Bu11. 1236, 132 p.

Reed, R. D., 1925, The post-Monterey disturbance in the Salinas Valley, California: Jour. Geology, v. 33, no. 6, p. 588-607. 
Reiser, H. N., 1970, Northeastern Brooks Range--a surface expression of the Prudhoe Bay Section, in Geological seminar on the North Slope of Alaska, Palo Alto, Calif., 1970, Proc.: Am. Assoc. Petroleum Geologists, Pacific Sec., p. K1-K13.

Resser, C. E., and Howe11, B. F., 1938, Lower Cambrian Olenellus Zone of the Appalachians: Geol. Soc. America Bull., v. 49, no. 2, p. 195-248.

Richards, H. G., 1958, Ordovician fossils from Montgomery County, Pennsylvania: Pennsylvania Acad. Sci. Proc., v. 32, p. 139-140.

Roberts, J. K., 1923, Triassic basins of northern Virginia: Pan-Am. Geologist, v. 39, no 3, p. 185-200.

Sable, E. G., 1977, Geology of the western Romanzof Mountains, Brooks Range, northeastern Alaska: U.S. Geol. Survey Prof. Paper 897, $84 \mathrm{p}$.

Sando, W. J., Mamet, B. L., and Dutro, J. T., Jr., 1969, Carboniferous megafaunal and microfaunal zonation in the northern Cordillera of the United States: U.S. Geo1. Survey Prof. Paper 613-E 29 p.

Schenck, H. G., and Kleinpe11, R. M., 1936, Refugian stage of the Pacific coast Tertiary: Am. Assoc. Petroleum Geologists Bull., v. 20, no. 2 , p. 215-225.

Schrader, F. C., 1899, Report on Prince William Sound and the Copper River region, in Maps and descriptions of routes of exploration in Alaska in $1 \overline{898}$, with general information concerning the territory: U.S. Geol. Survey Spec. Pub., p. 51-63. , 1900, A reconnaissance of a part of Prince William Sound and the Copper River district, Alaska, in 1989: U.S. Geol. Survey 20th Ann. Rept., pt. 7, p. 341-423.

Shaver, R. H., and others, 1970, Compendium of rock-unit stratigraphy in Indiana: Indiana Geol. Survey Bu11. 43, $229 \mathrm{p}$.

Stainbrook, M. A., 1947, Brachiopoda of the Percha shale of New Mexico and Arizona: Jour. Paleontology, v. 21, no. 4, p. 297-328.

Stose, G. W., and Jonas, A. I., 1922, The lower Paleozoic section of southeastern Pennsylvania: Washington Acad. Sci. Jour., v. 12, no. $15, \mathrm{p} .358-366$.

, 1939, Geology and mineral resources of York County, Pennsylvania: Pennsylvania Geol. Survey, 4th ser., Bull. C-67, 199 p.

Stose, A. J., and Stose, G. W., 1944, Geology of the Hanover-York district, Pennsylvania: U.S. Geol. Survey Prof. Paper 204, 84 p.

Stoyanow, A. A., 1926, Recent stratigraphic work in Arizona, expecially Upper Mississippian in southeastern Arizona: Am. Jour. Sci., 5th ser., v. 12, p. 316-318.

Tabor, R. W., and Cady, W. M., 1978, Geologic map of the 0lympic Peninsula Washington: U.S. Geol. Survey Misc. Geol. Inv. Map I-994, 2 sheets. 
Thompson, J. B., Jr., Robinson, Peter, Clifford, T. N. and Trask, N. J., Jr., 1968, Nappes and gneiss domes in west-central New England, Chap. 15 in Studies of Appalachian geology, northern and maritime, Zen, E-an, and others, eds.: New York, Interscience Publishers, John Wiley and Sons, p. 203-218.

Tysda1, R. G., and Case, J. E., 1977, Placer River fault, Seward and Blying Sound quadrangles, in Blean, K. M., ed., The United States Geological Survey in Alaska: Accomplishments during 1976: U.S. Geol. Survey Circ. 751-B, p. B47-B48.

, in press, Geologic map of the Seward and Blying Sound quadrangles, southern Alaska: U.S. Geol. Survey Misc. Geol. Inv. Map I-1150.

Tysdal, R. G., Case, J. E., Winkler, G. R., and Clark, S. H. B., 1977, Sheeted dikes, gabbro, and pillow basalt in flysch of coastal southern Alaska: Geology, v. 5, no. 6, p. 377-383.

U1rich, E. 0., 1904, Fossils and age of the Yakutat Formation, in Harriman Alaska Expedition, v. 4, Geology and Paleontology: New York, Doubleday, Page and Co., p. 125-146.

Weaver, C. E., 1937, Tertiary stratigraphy of western Washington and northwestern Oregon: Washington Univ. Pub. in Geology, v. $4,266 \mathrm{p}$.

Weaver, D. W., Griggs, G., McClure, D. V., and McKey, J. R., 1969, Volcaniclastic sequence, south-central Santa Cruz Island, in Weaver, D. W., and others, eds., Geology of the Northern Channel Islands, southern California borderland: Am. Assoc. Petroleum Geologists/Soc. Econ. Paleontologists and Mineralogists, Pacific Secs., Spec. Pub., p. 85-90.

Wells, F. G., Hotz, P. E., and Cater, F. W., Jr., 1948, Preliminary description of the geology of the Kerby quadrangle, Oregon: U.S. Geol. Survey, prepared in co-op. wtih Oregon Dept. Geology and Mineral Industries, 23 p.; 1949, reprinted as Oregon Dept. Geology and Mineral Industries Bul1. 40, $23 \mathrm{p}$.

Wilson, C. W., Jr., 1949, Pre-Chattanooga stratigraphy in central Tennessee: Tennessee Dept. Conserv., Div. Geology Bull. 56, 407 p.

Winkler, G. R., and Plafker, George, 1975, The Landlock fault: Part of a major early Tertiary plate boundary in southern Alaska, in Yount, M. E., ed., United States Geological Survey Alaska Program, 1975: U.S. Geol. Survey Circ. 722, p. 49.

Woodring, W. P., and Bramlette, M. N., 1950, Geology and paleontology of the Santa Maria district, California: U.S. Geol. Survey Prof. Paper 222, 185 p. 
Wornardt, W. W., Jr., 1967, Siliceous microfossils from the Bickmore Canyon diatomite and the Pancho Rico Formation, in Guidebook to Gabilan Range and adjacent San Andreas fault--American Association of Petroleum Geologists and Society of Economic Paleontologists and Mineralogists, Pacific Secs. Joint Ann. Field trip, October 20-21, 1967: Am. Assoc. Petroleum Geologists, Pacific Sec., p. 48-53.

Yochelson, E. L., 1970, The Early Cambrian fossil Salterella conulata Clark in eastern North America: U.S. Geo1. Survey Prof. Paper $683-\mathrm{B}, 10 \mathrm{p}$.

Young, Keith, 1965, A revision of Taylor nomenclature, Upper Cretaceous, central Texas: Texas Univ. Bur. Econ. Geology Geol. Circ. 65-3, $10 \mathrm{p}$.

Zeller, R. A., 1965, Stratigraphy of the Big Hatchet Mountains area, New Mexico: New Mexico Bur. Mines and Mineral Resources Mem. $16,128 \mathrm{p}$. 


\section{AUTHOR INDEX}

Addicott, w. $0 .$, A21, 26, 31, $38(2), 48,53(2), 56,58,85$, 88 ; see Plafker, George, A86

*Armstrong, A. K., A13, 26, 36, $38,83,85,90$

* Banks, N. G., A10, 68

Barosh, P. J., A25, 54, 59

Berdan, J. M., A7, 20, 23, 39, $46,74,83,84$

*Berg, H. C., A35, 78

Bird, K. J., see Armstrong, A. K., A26, $\overline{36}$

Blade, L. V., A6

Blake, M. C., Jr., see Hose, R. K., A17, 23

Bohannon, R. G. , A7, 33, 49, 56

Brabb, E. E., see Poore, R. Z., A63, 68, 81

Bressler, S. L., see Elston, D. P., A77

Brosgé, W. P., see Reiser, H. N., A51, 106

*Brown, C. E., A9, 13, 14, 30, 35, $50,51,53,61,62,64,76,82$

Buffington, E. C., see Scholl, D. W., A19, 84

*Bybe11, L. M., Al 3

Bybel1, L. M., see Hazel, J. E., A9, $15,57,6 \overline{5,66,71,75,77,}$ $80,83,85$

*Cameron, C. C. , A36, 48, 67

*Carter, Claire, A58, 80

Christopher, R. A., see Hazel, J. E., A9, $15,57,65,66$, $71,75,77,80,83,85$

Churkin, Michael, Jr., see Carter, Claire, A58, 80

Clardy, B. F., see Wise, 0. A., $\mathrm{Jr}$., A10, 75

Clarke, J. M., see Lukert, M. T., A27

*Senior author of paper with multiple aut ho rship.
*Coats, R. R., A22, 30, 37(2), $60,72,74$

Cobban, W. A., see Hook, S. C., A54; see Landis, E. R., A70; see Merewether, E. A., A20, $54,66,67,81$

Cress, L. D., see Coats, R. R., A22, $30,37(2), 60$, 72,74

*Crowe, B. M., A23, 32, 61, 69,75

*Csejtey, Béla, Jr., A6

Curet, A. F., see Krushensky, R. D., $A 4,4 \overline{0}$

Detterman, R. L., see Imlay, R. W., A39

Dixon, H. R., see Goldstith, Richard, A5l

Douglass, R. C., see Morris, H. T., A28, 56

Drewes, Hara1d, A21, 59, 63, 69,86

Dutro, J. T., Jr., see Reiser, H. N., A51, 106

Eberlein, G. D., see Csejtey, Béla, Jr., A6

Eicher, D. L., see Pillmore, C. L., Al1, $12,14,27,31$, $33,37,42$

Elliott, R. L., see Berg, H. C. , A35, 78

*E1ston, D. P., A77

Fredericksen, N. 0., see Hazel, J. E., A9, 15,57 , $65,66,71,75,77,80,83$, 85

Gibbons, A. B., see Swadley, W. C., $A 24,45,66$

*Gohn, G. S., A8, 21

Gohn, G. S., A20, 41, 94

*Goldsmith, Richard, A51

Govoni, D. L., see Bybe11, L. M., A13 
Green, R. C., see Coats,

R. R., A22, $30,37(2), 60$, 72,74

*Hackman, R. J., A19

Hail, W. J., Jr., A32, 76

Hait, M. H., Jr., see Skipp, Bet ty, A8

Hal1, D. F., see Leo, G. W., A9, $26,30, \overline{52}, 60$

Hansen, W. R., A24, 34

*Harris, L. D., Al0, 14, 15, $34,51,72$

*Haze1, J. E., A9, 15, 57, $65,66,71,75,77,80$, 83,85

Hedge, C. E., see Poole, F. G., A47

Hedlund, D. C., A29

*Hein, J. R., A3, 11

Henry, T. W., see Sutherland, P. K., $A 12(2), 19,31,47$, 70

Hietanen, Anna, A11

Higgins, B. B., see Gohn, G. S., A8, A21

*Higgins, M. H., A18, 26,46, $44,60,65,68,87,98$

Higgins, R. E., see Crowe, B. M., A23, 32, 61, 69, 75

Himmelberg, G. R., see Loney, R. A., A37

*Hook, S. C., A54

*Hose, R. K., A17, 23

Hotz, P. E., A4, 24, 28, 49, 73 ; see Potter, A. W., A4, $25, \overline{74}$

Howel1, D. G., see Crowe, B. M., A23, 32, 61, $\overline{69}, 75$; see

McLean, Hugh, A10

*Imlay, R. W. , A39

Irwin, W. P., A3, 21, 33, 67

Kepferle, R. C., A28, 50; see Provo, L. J., A18, 52, 55, 79

Ketner, K. B., see Smith, J. F., Jr. , A43

Kimball, A. L., see Berg, H. C., A35, 78

Kopf, R. W., see Morris, H. T., A28, 56

Krieger, M. H., A61; see Banks, N. G., A10, 68

*Krushensky, R. D., A4, 40
*Landis, E. R., A70

Lanphere, M. A., see Csejtey, Béla, Jr., A6

Lee, K. Y., A6, 13, 41, 45, 52, 62

*Leo, G. W., A9, 26, 30, 52, 60

Lipman, P. W., A14, 33, 73

*Loney, R. A., A37

Lovering, T. S., see Tweto, Ogden, Al6, 22, 25, 29, 40,57

*Ludwig, K. R., A40

*Lukert, M. T., A27

Magathan, W. J., see Merewether, E. A., A20, 54,67

Mamet, B. L., see Armstrong, A. K., A13, 38, 83, 85, 90

Manley, Kim, A3, 16, 69, 78

*Manley, Kim, A78

Marks, L. Y., see Coats, R. R., $\mathrm{A} 22,30,37(\overline{2)}, 60,72,74$

Marlow, M. S., see Scholl, D. W., A19, 84

Marvin, R. F., see 0lson, J. C., A29, 46; see Poole, F. G., A47

Matson, R. M., see Merewether, E. A., $\mathrm{A} 20,5 \overline{4,67}$

*Matti, J. C., A80

Maughan, E. K., A47, 58, 62

May, F. E., see Hazel, J. E., A9, $15,57,65,66,71,75,77,80$, 83,85

McConnell, K. I., see Higgins, M. H., A18, $26, \overline{43}, 44,60,65$, $68,87,98$

McDowel 1, R. C., see Weir, G. W., A6, 76

McGrew, L. W., A28; see Skipp, Betty, A7, 42(2), 46, 70

McKee, E. H, see Matti, J. C., A80

McLean, D. M., see Hazel, J. E., A9, $15,57,6 \overline{5,66,71,75,77, ~}$ $80,83,85$

*McLean, Hugh, A10

McLean, Hugh, see Crowe, B. M., A23, 32, 61, 69, 75; see Hein, J. R., A3, 11

McLeod, N. S., see Scholl, D. W., A19, $8 \overline{4}$ 
Mehnert, H. H., see 0lson, J. C., A29, 46

Meissner, C. R., Jr., see Miller, R. L., A8, 22, 30, 39, 54, 85

*Merewether, E. A., A20, 54, 66, 67,81

M'Gonigle, J. W., A23, 59, 64, *Milici, R. C., A27, 36, 65, 71, 72,74

Milici, R. C., see Harris, L. D., $A 10,1 \overline{4,} 15,34$, 51,72

*Miller, R. L., A8, 22, 30, 39, 54,85

Monroe, W. H., see Pease, M. H., Jr., A49, 80

Morgan, B. A., III, A7, 58

*Morris, H. T., A28, 56

Mory, P. C., see Cameron, A36, 48,67

Mudge, M. R., A3, 5, 9, 32

Naeser, C. W., see Manley, Kim, A78; see Triplehorn, D. M., A19, 34

Nelson, W. H., see Csejtey, Béla, Jr., A6

Niem, A. R., see Snavely, P. D., $\mathrm{Jr} ., \mathrm{A} 34,4 \overline{4,} 61,81,111$

Nilsen, T. H., A22, 47

Norris, D. K., see Reiser, H. N., A51, 106

Nuckols, E. B., see Lukert, M. T., A27

Obradovich, J. D., see Pearson, R. C., A29, $39,57,68,79$

Olson, A. B., see Hackman, R. J., A19

*01son, J. C., A29, 46

otton, J. K. Al7

Owens, J. P., see Gohn, G. S., A8, 21

Parker, R. L., see 01son, J. C., A29, 46

Pearl, J. E., see Snavely, P. D., Jr., A34, 44, 61, 81, 111
*Pearson, R. C., A29, 39, 57, 68,79

*Pease, M. H., Jr., A49, 80

Peper, J. D., A49, 52

*Pillmore, C. L., Al1, 12, 14, $27,31,33,37,42$

Pittman, T. L., see Berg, H. C., $\mathrm{A} 35,78$

*Plafker, George, A86

Plafker, George, see Tysdal, R. G., A120

Platt, L. B., A35

*Poole, F. G., A47

Poole, F. G., see Sandberg, C. A., A46, $48,50,62,69$, 78,79

*Poore, R. Z., A63, 68, 81

Poore, R. Z., see Hazel, J. E., A9, $15,57, \overline{65,} 66,71,75$, $77,80,83,85$

*Potter, A. W., A4, 25, 74

Potter, P. E., see Provo, L. J., A18, $5 \overline{2,55,79}$

*Provo, L. J., A18, 52, 55, 79

*Reiser, H. N., A51, 106

Repetski, J. E., A48, 107

Rice, C. L., A15, 41, 42, 64, 76,108

Rice, D. D., A5(2), 20, 57, 82(2)

Robinson, Peter, see Leo, G. W., A9, 26, $30,52,60$

Rohr, D. M., see Potter, A. W., $\mathrm{A} 4,25,74$

Ryder, R. T., see Merewether, E. A., A66, 81

*Sandberg, C. A., A46, 48, 50, $62,69,78,79$

Sando, W. J., A17, 44, 56, 67, 86,110

*Schol1, D. W., A19, 84

*Seiders, V. M., A82

Sharp, W. N., A49

Silver, L. T., see Ludwig, K. R., A40 
*Skipp, Betty, A7, 8, 42(2), 46, 70

Smith, C. C., see Gohn, G. S., A8, 21 ; see Haze 1, J. E., A9, 15, 57, $65,66,71,75,77,80,83,85$

*Smith, J. F., Jr., A43

Smith, J. G., Al1, 36; see Berg, H. C., A35, 78; see Csejtey, Béla, Jr., A6

*Snavely, P. D., Jr., A34, 44, 61, 81,111

Soh1, N. F., see Hazel, J. E., A9, $15,57,65, \overline{66}, 71,75,77,80$, 83,85

*Sutherland, P. K., A12(2), 19, 31, 47,70

*Swadley, W. C., A24, 45, 66

Taylor, A. R., Al6, 18, 43, 44, $55(2), 59,60,63,73(2), 77,81$

Thayer, T. P., see Brown, C. E., $A 9,13,14,30,35,50,51,53$, $61,62,64,76,82$

*Triplehorn, D. M., A19, 34

Turner, D. L., see Triplehorn, D. M., A19, 34

*Tweto, Ogden, Al6, 22, 25, 29, 40, 57

*Tysdal, R. G., Al20

Valentine, P. C., see Hazel, J. E., A9, $15,57,65, \overline{66}, 71,75,77$, $80,83,85$

Vallier, T. L., A24, 35, 40, 45, $71,84(2)$

Vedder, J. G., see McLean, Hugh, Al0

Wedow, Helmuth, Jr., see Milici, R. C., A27, $36,65,71,72,74$

*Weir, G. W., A6, 76

*Wise, 0. A., Jr., A10, 75

Witmer, R. J., see Hazel, J. E., A9, $15,57,65,66,71,75,77$, $80,83,85$

Wo1fe, J. A., A4, 71

Wright, J. E., see Seiders, V. M., A82

Yochelson, E. L., see Wise, O. A., Jr., Al0, 75

Zietz, Isadore, see Goldsmith, Richard, A51

t) U.S. Government Printing Office: 1979-281-359/11 





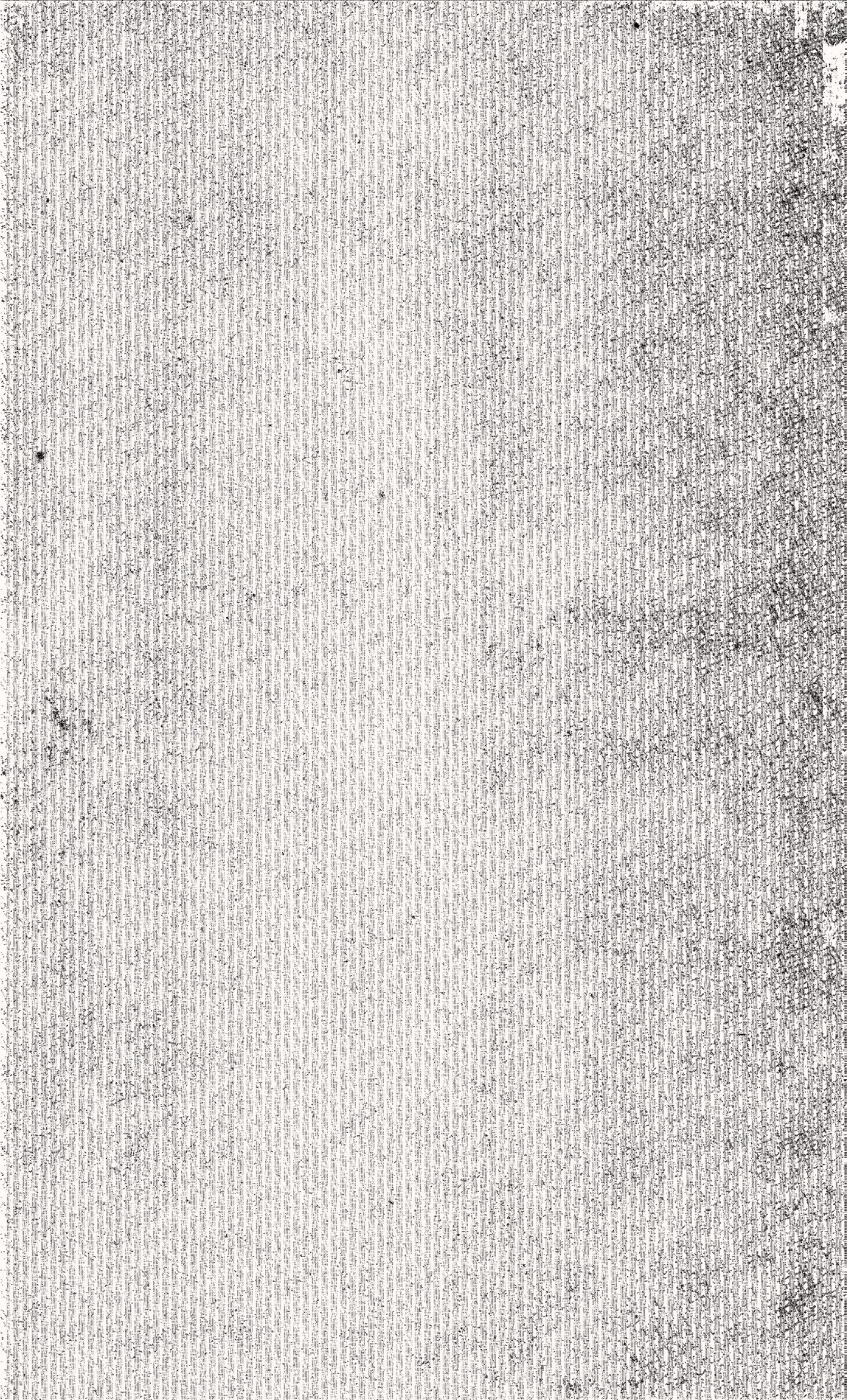

